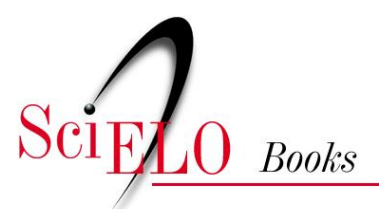

\title{
Difíceis decisões
}

etnografia de um Centro de Tratamento Intensivo

Rachel Aisengart Menezes

\section{SciELO Books / SciELO Livros / SciELO Libros}

MENEZES, RA. Difíceis decisões: etnografia de um Centro de Tratamento Intensivo [online]. Rio de Janeiro: Editora FIOCRUZ, 2006. 107 p. ISBN 978-85-7541-313-5. Available from SciELO Books $<\underline{\text { http://books.scielo.org }>\text {. }}$

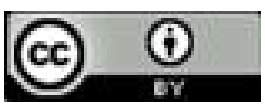

All the contents of this work, except where otherwise noted, is licensed under a Creative Commons Attribution 4.0 International license.

Todo o conteúdo deste trabalho, exceto quando houver ressalva, é publicado sob a licença Creative Commons Atribição 4.0.

Todo el contenido de esta obra, excepto donde se indique lo contrario, está bajo licencia de la licencia $\underline{\text { Creative }}$ Commons Reconocimento 4.0. 


\section{Difíceis Decisões: etnografia de um Centro de Tratamento Intensivo}




\section{FUNDAÇÃO OSWALDO CRUZ}

Presidente

Paulo Marchiori Buss

Vice-Presidente de Ensino,

Informação e Comunicação

Maria do Carmo Leal

\section{EDITORAFIOCRUZ}

Diretora

Maria do Carmo Leal

Editor Executivo

João Carlos Canossa Pereira Mendes

Editores Científicos

Nísia Trindade Lima e Ricardo Ventura Santos

Conselho Editorial

Carlos E. A. Coimbra Jr.

Gerson Oliveira Penna

Gilberto Hochman

Lígia Vieira da Silva

Maria Cecília de Souza Minayo

Maria Elizabeth Lopes Moreira

Pedro Lagerblad de Oliveira

Ricardo Lourenço de Oliveira

Coleção Antropologia e Saúde

Editores Responsáveis: Carlos E. A. Coimbra Jr.

Maria Cecília de Souza Minayo 


\title{
Difíceis Decisões: etnografia de um Centro de Tratamento Intensivo
}

\author{
Rachel Aisengart Menezes
}


Copyright@ 92006 da autora

Todos os direitos desta edição reservados à

Fundação Oswaldo Cruz / Editora FiocruZ

ISBN: 85-7541-100-4

Projeto Gráfico e Editoração Eletrônica:

Guilherme Ashton

Capa:

Danowski Design

Ilustração da Capa:

A partir da gravura de Hans Arp, Siamese Leaves, 1949

Revisão e Copidesque:

Marcionílio Cavalcanti de Paiva

Catalogação-na-fonte

Centro de Informação Científica e Tecnológica

Biblioteca Lincoln de Freitas Filho

M543d Menezes, Rachel Aisengart

Difíceis decisões: etnografia de um Centro de Tratamento Intensivo. /

Rachel Aisengart Menezes. - Rio de Janeiro : Editora Fiocruz, 2006. $107 \mathrm{p}$.

1.Unidades de Terapia Intensiva. 2.Tomada de decisões. 3.Prática profissional. 4.Antropologia cultural. I.Título.

CDD - 20.ed. - 362.174

2006

EDITORA FIOCRUZ

Av. Brasil, 4036 - $1^{\circ}$ andar - sala 112 - Manguinhos

21040-361 - Rio de Janeiro - RJ

Tels.: (21) 3882-9039 e 3882-9041

Telefax: (21) 3882-9006

http://www.fiocruz.br/editora

e-mail: editora@fiocruz.br

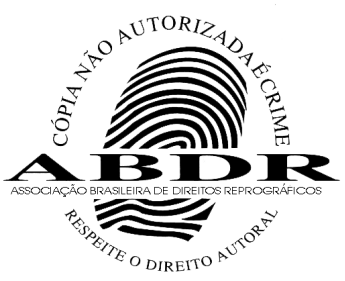


À memória de meu pai e de Tiago. 



\section{SUMÁRI0}

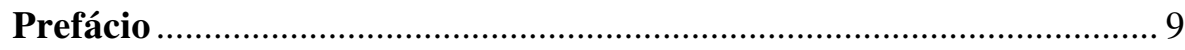

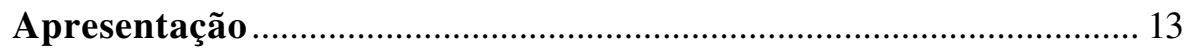

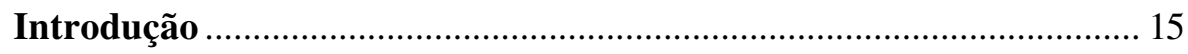

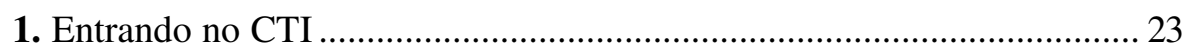

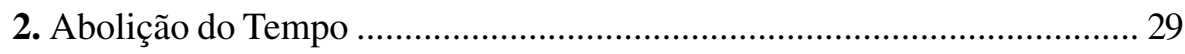

3. Intensivista como Identidade Profissional ................................................ 47

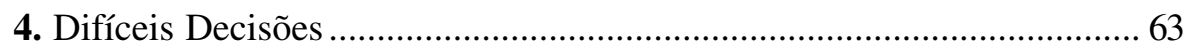

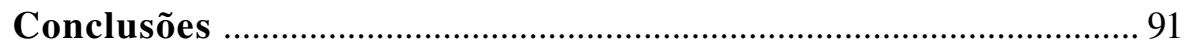

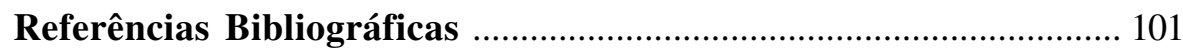

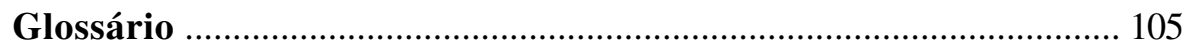





\section{Prefácio}

Atenção, leitor! Este é um trabalho sobre os limites da vida e sobre os limites da esperança humana. É grave, portanto. A medicina - com seus vastos instrumentos - é aqui examinada à luz crua, artificial, ininterrupta, dos Centros hospitalares de Tratamento Intensivo (CTIs), arena e limiar inquietante de sua capacidade de propiciar a saúde e a vida.

Conheci o trabalho ao participar da banca que o examinou, em 2000, como dissertação de mestrado do Instituto de Medicina Social da Universidade Estadual do Rio de Janeiro (Uerj). Chamou-me a atenção, desde logo, a qualidade da etnografia, da descrição antropológica, de uma dimensão tão secreta e misteriosa da vida institucional hospitalar moderna - tão grave e temida, aliás, quanto secreta e misteriosa. Diferentemente do que advertia Dante às portas do Inferno - "lasciate ogne speranza voi ch'intrate" -, há aqui a esperança tipicamente antropológica de um conhecimento densamente produzido, de uma objetivação elaborada, de um senso de ordem e sentido, precipitável mesmo nos piores círculos de nosso inferno imanente.

Chamou-me, nesse sentido, particularmente a atenção a sensibilidade aguçada da pesquisadora aos meandros desse fragmento tão peculiar da vida social e seu esforço em explicitar, com lúcida reflexividade, as condições em que foi possível fazer a sua observação, compreender sua lógica, apreender suas contradições e tensões. Sua identidade de médica, ainda que treinada em psicanálise e em antropologia, esteve sempre na linha de frente das negociações da pesquisa de campo, ao mesmo tempo como garantia e desafio de uma etnografia da vida institucional hospitalar.

Essa condição anfíbia, bem conduzida, permitiu à autora apresentar um caso empírico iluminador do grande confronto entre o processo de racionalização do mundo, que se vem constituindo há séculos no Ocidente pela institucionalização e profissionalização dos conhecimentos e cuidados médicos, e a continuada resistência da morte, da destruição e decadência corporal, das doenças graves, crônicas ou terminais. É num CTI que se encena uma das mais renhidas batalhas entre essa racionalização e essa resistência. As condições-limite desse processo 
são a base da etnografia aqui empreendida: uma bolha institucional, um experimento controlado, uma caixa técnica, caracterizada por uma máxima concentração das tecnologias médicas, das mais 'duras' às mais 'brandas', dos aparelhos mais modernos de monitoramento das funções vitais às técnicas mais atualizadas do atendimento de enfermagem, de fisioterapia ou de psicologia. Nessa caixa, cujo ritmo é mantido impecável por um corpo técnico altamente especializado e treinado, entram e saem continuamente pacientes e cadáveres. Ao máximo de esperança social materializada no complexo médico-hospitalar contrapõe-se o máximo de desafio da manutenção da vida. Ela, ali, entra literalmente por um fio e desse fio pende a espada de Dâmocles de todos os atores envolvidos. A tensão e o sofrimento dos profissionais - tal como os descreve e analisa Rachel Menezes não são menores do que os de seus pacientes (e dos familiares destes, inquietamente mantidos num regime controlado de acesso físico e informacional). 'Panela de pressão' é uma significativa imagem, ali usada, dos efeitos psicológicos da distância entre as expectativas de um corpo profissional treinado para medir o sucesso em termos estatísticos e a reiterada e crua experiência do insucesso.

A etnografia da racionalização é muito esclarecedora. Ela abrange a formação do profissional-chave do processo (o 'intensivista'), a arquitetura e disposição espacial do Centro, a parafernália técnica de alta qualidade disponível, e - acima de tudo - os ritmos, rotinas e modos comportamentais que caracterizam esse espaço como um modelo reduzido e ideal da experiência hospitalar. A temporalidade é, aí, particularmente vigiada. Os técnicos falam de 'dedicação 24 horas', de 'atividade máxima', de 'otimização do tempo'; falam de um processo de fino e contínuo monitoramento dos tempos diversos envolvidos e imbricados uns nos outros. Uma contínua, ininterrupta cronometragem, vigilância, controle.

Aos pacientes, no entanto, se lhes tira os relógios: à máxima minúcia e precisão do tempo médico deve corresponder uma máxima suspensão da experiência temporal dos doentes; tanto quanto da sua experiência espacial. O ideal do paciente 'anônimo e submisso' já aí se percebe in actu. As entradas e saídas na caixa devem ser o mais mecânicas possível: números e séries de preferência a nomes e feições.

A etnografia da racionalização se entrecruza com a etnografia do desamparo. Desamparo entrevisto dos pacientes; mas desamparo sobretudo dos profissionais, expostos à permanente impossibilidade de garantir a efetivação do modelo ideal de sua prática. "É muita morte, é morte demais", declara um deles à pesquisadora, resumindo o mal-estar ante a série de 'difíceis decisões' a serem tomadas nos processos de atendimento. Avaliações de 'viabilidade' diferencial dos doentes, 
de momentos diferenciais de 'viabilidade' e conveniência de intervenção trazem à tona os fantasmas recorrentes em nossa cultura sobre a possibilidade - desejo ou pavor - da eutanásia. Desamparo também no registro menor da dor - não apenas no da morte. Os pacientes, afinal, têm nomes e feições, tanto quanto cada um dos profissionais, em seus mais diversos níveis. Os mecanismos da caixa rangem com a intromissão das relações interpessoais, dos fluxos afetivos e comunicacionais. A tensão é permanente entre os horizontes e investimentos dos tripulantes permanentes e os dos passageiros fugazes, tantas vezes derradeiros.

Muitas outras dimensões experienciais e institucionais são desvendadas pela autora nesse nódulo crítico de nossa organização cultural. A mim, me tocou particularmente a informação sobre as dimensões de 'psicologização' aí envolvidas. Psicólogos fazem parte do corpo profissional. Seu papel, em um contexto tão exacerbado emocionalmente, é complexo e desafiador: uma espécie de mediação técnica entre as dimensões interiorizadas do ideal de racionalização e as condições efetivas da vida psíquica em qualquer circunstância - e tanto mais em face da dor, do desamparo, da morte. Significativamente, é uma psicóloga informante deste trabalho que mais claramente enuncia em dado momento um ideal - o da boa morte, o da morte com 'qualidade de vida' - que Rachel Menezes veio a estudar em sua tese de doutorado, já agora realizada, com idêntico sucesso, e publicada (Menezes, 2004).

Permitam-me uma intrusão pessoal. Tive neste ano - eu próprio -, pela primeira vez, a experiência de uma internação em CTI. Quando Rachel lá me visitou, disse-lhe o quanto me recordava deste seu trabalho. Talvez não lhe tenha dito que a clareza e dignidade que emanam de seu relato me ajudaram a elaborar as minhas próprias racionalizações e objetivações sobre aquela situação; essas que defendem a lucidez possível em momentos de angústia e desamparo. Mas, afinal, é esse mesmo o sentido de toda a humana elaboração simbólica, exposta ao labirinto desafiador da vida. A diferença, num trabalho como este, é a justeza da via, a coerência dos passos, a finura da trama do fio com que ligamos os pontos do roteiro e nos aproximamos e enfrentamos, a cada curva dos meandros, o irredutível Minotauro da dúvida, da perplexidade, da opacidade.

\section{Luiz Fernando Dias Duarte}

Doutor em Antropologia e professor adjunto do Programa de Pós-Graduação em Antropologia Social do Museu Nacional da Universidade Federal do Rio de Janeiro (UFRJ) 



\section{Apresentação}

Este livro está fundamentado em minha dissertação de mestrado em saúde coletiva, apresentada ao Instituto de Medicina Social da Universidade do Estado do Rio de Janeiro (IMS/Uerj), em março de 2000, denominada Difíceis Decisões: uma prática antropológica da prática médica em CTI (Menezes, 2000). Ela marcou o início de minha trajetória em pesquisa, voltada mais especificamente às áreas da saúde coletiva e antropologia da biomedicina, e destaca sua instituição paradigmática, o hospital e seus profissionais.

A etnografia de um Centro de Tratamento Intensivo (CTI) de um hospital público universitário do Rio de Janeiro é uma investigação sobre a complexidade que permeia o difícil processo de tomada de decisões sobre a vida e a morte. Este livro relata a observação realizada em um hospital público, escolhido por ser um espaço onde a assistência em saúde é capaz de expressar as desigualdades e tensões sociais presentes tanto entre as diversas categorias profissionais quanto entre equipe, pacientes e seus familiares - alvo do interesse da pesquisa. A opção por um hospital universitário deve-se à possibilidade de apreensão do processo de transmissão de conhecimento dos objetos e valores preeminentes na assistência em saúde, em especial na formação dos médicos.

O CTI é um microcosmo que reflete - de forma aguda, tendo em vista a gravidade e a liminaridade da situação vivida pelos doentes ali internados - representações sociais mais amplas, referentes à doença/saúde, vida/morte, juventude/ velhice, entre outras.

Desde meus primeiros contatos com o hospital público - ainda cursando a faculdade de medicina - o processo de tomada de decisões médicas relativas à doença e ao sofrimento dos pacientes constituíram objeto de meu interesse. No mestrado, tive acesso a uma produção teórica voltada ao estudo das formas de interação entre os diversos atores sociais no que concerne à saúde e aos valores envolvidos.

Tendo como fundamento essa bibliografia das ciências sociais, desenvolvi a pesquisa que deu origem a este livro. No primeiro capítulo, descrevo minha entrada no campo - o Centro de Tratamento Intensivo -, a metodologia utilizada, 
assim como as reações da equipe à minha observação. No segundo faço uma descrição geral desse setor hospitalar, apresentando a seguir os atores que se movimentam nesse espaço e suas tarefas profissionais. O terceiro capítulo é dedicado à análise do modo pelo qual é construída a identidade profissional dos integrantes do CTI, as relações entre as diversas categorias profissionais que compõem o próprio grupo dessa unidade e as relações com os outros serviços do hospital. O quarto capítulo contempla uma discussão sobre o processo de tomada de decisões por parte dos profissionais do centro observado, e o modo como tais decisões são formuladas, tendo como pano de fundo um 'sistema' classificatório dos doentes internados. A partir das diversas categorias produzidas pelo grupo profissional, decisões são tomadas quanto ao prolongamento da vida dos internados, nas quais a equação 'competência-cuidado' é atualizada sob distintas formas. Finalmente, nas conclusões, são apresentadas algumas questões que permanecem em aberto e possibilidades de investigação no campo. Uma vez que várias falas de profissionais contêm termos técnicos da biomedicina, foi elaborado um glossário para facilitar a leitura.

A pesquisa no Centro de Tratamento Intensivo somente foi possível graças à abertura de suas portas à observação. Agradeço, portanto, às chefias do hospital e do CTI e, especialmente, às equipes que ali trabalhavam, por sua paciência diante de minhas perguntas.

Em minha trajetória no Instituto de Medicina Social da Uerj tive o privilégio de contar com a orientação atenta e amiga de Sérgio Carrara, que soube sempre encontrar a melhor forma de me conduzir à clareza. Agradecimentos especiais também a Maria Luiza Heilborn, tanto por sua contribuição decisiva para a definição do objeto de pesquisa como por suas ricas sugestões. 


\section{Introdução}

A idéia da pesquisa teve origem na experiência vivida em trabalho voluntário no atendimento a pacientes soropositivos e seus acompanhantes, em sala de espera ambulatorial de um hospital público da cidade do Rio de Janeiro. Diante do agravamento do quadro de alguns doentes, perceberam-se mudanças na postura de membros da equipe profissional, que se afastavam desses pacientes e seus familiares. Esse tipo de reação motivou a investigação: dar enfoque ao exercício dos profissionais da saúde, quando colocados diante da iminência da morte de seus pacientes. A escolha lógica foi observar a prática da equipe de saúde em um setor específico do hospital moderno: o Centro ou Unidade de Tratamento Intensivo (CTI ou UTI), local especialmente dedicado a doentes com grande risco de morte.

$\mathrm{Na}$ atualidade, o hospital ocupa um lugar central e quase naturalizado na sociedade ocidental, no que concerne à assistência em saúde, à doença e à morte. Essa centralidade é fruto de longo processo histórico, no qual os conceitos de saúde e doença foram transformados, e os caminhos da 'saúde/doença' balizados pela racionalização cientificista aplicada à natureza, em geral, e à corporalidade em particular. No cerne desse processo produziu-se o que se chama de biomedicina, que tem por objetivo responder à demanda da sociedade no que se refere ao sofrimento humano expresso no corpo (Duarte \& Leal, 1998).

A partir da década de 1960, surgiram diversos focos de insatisfação quanto ao papel e funcionamento do hospital, fazendo emergir uma crescente crítica social endereçada à medicina como um todo. Tal contexto foi fundamental para o desenvolvimento, no âmbito das ciências humanas, de um amplo campo de reflexão sobre a instituição hospitalar. De modo geral, as abordagens enunciam críticas à prática médica e hospitalar e, em especial, ao crescente processo de desumanização dos doentes. Muitos autores tratam desse tema.

As análises desenvolvidas por Michel Foucault sobre o processo histórico que originou o aparecimento do hospital constituem referência de especial importância. Em História da Loucura na Idade Clássica (1995), esse autor privilegiou o estudo dos espaços institucionais para controle do louco e sua construção histórica, 
demonstrando que o hospital psiquiátrico, a partir do fim do século XVIII, tornouse um campo de práticas terapêuticas com a introdução, em seu interior, de mecanismos disciplinares. Mediante tais mecanismos, é ainda Foucault quem esclarece, que os loucos passaram a ser submetidos a uma intervenção simultaneamente objetiva e objetificante, autorizada e autoritária.

Já em seu outro livro, O Nascimento da Clínica (1994), o autor mostra que o hospital geral, como instrumento terapêutico, é uma invenção relativamente recente, do fim do século XVIII, concomitante à mutação no conhecimento que instituiu a racionalidade anátomo-clínica estruturante da medicina moderna. Antes do século XVIII, o hospital era essencialmente uma instituição de assistência aos pobres, administrada por religiosos, em nada se parecendo com medicina hospitalar. Assim, o hospital deveria funcionar tanto para recolhê-los quanto para proteger os outros do perigo de contaminação. Era, pois, um espaço dedicado à assistência, separação e exclusão - não do doente a ser curado, mas do pobre destinado a morrer: era um 'morredouro' (Foucault, 1979). Ao findar o século XVIII, os elementos constituintes das patologias são reorganizados e a medicina passa a produzir um discurso científico sobre o indivíduo, sua saúde e doença. O hospital medicalizado originou-se, portanto, do ajuste de dois processos: o deslocamento dos cuidados - dos religiosos para os médicos - e a 'disciplinarização' do espaço institucional, tornando-se um meio de intervenção sobre o doente, com arquitetura e funcionamento específicos. Em seu interior, emergiu então um importante personagem - o médico de hospital. A instituição passa então a ser não somente lugar de cura, mas também espaço de produção e transmissão de saber (Foucault, 1979).

Outros autores desenvolveram estudos sobre a instituição hospitalar, enfocando o exercício do poder médico sobre o indivíduo internado - seja por loucura, doença - ou até mesmo no momento da morte. Em Internados: ensayos sobre la situación social de los enfermos mentales (1972), ${ }^{1}$ Erving Goffman, da Escola de Chicago, critica o hospital psiquiátrico, principalmente, por ser um espaço onde se dá um processo de redução do estatuto social do adulto livre a paciente, medicamente controlado. Há perda de sua autonomia e identidade. O autor centra-se no papel e na carreira moral do doente internado em instituição psiquiátrica e descreve, com base em seu conceito de 'instituição total', a organização da vida desses pacientes no hospital psiquiátrico. Para Goffman, 'instituição total' refere-se a espaços sociais de residência e de trabalho onde um grande número de indivíduos é despido de sua singularidade, separado do mundo exterior por certo tempo, compartilhando uma situação de reclusão, submetido a regras institucionais (Goffman, 1972). 
A perda de autonomia do doente internado é também enfocada por Anselm Strauss (1963).

A vida das organizações é entendida como o resultado de uma vasta e variada gama de negociações, na qual a ênfase recai na relação entre regras institucionais e processos de negociação, desenvolvidos por equipes de saúde e outros atores sociais envolvidos. Uma outra linha de análise crítica abordou o hospital a partir da discussão em torno das profissões. Freidson (1988), investiga o campo das profissões e postula que, de todas as categorias profissionais envolvidas na complexa divisão do trabalho em saúde, a única verdadeiramente autônoma seria a profissão médica. Sua autonomia é sustentada pelo monopólio de um saber e pela competência técnica, centrais na organização da divisão do trabalho. A medicina deteria uma posição dominante na divisão de trabalho, o que se dá de modo diferente de qualquer outra categoria profissional, refletindo a existência de uma hierarquia de competência institucionalizada (Freidson, 1988). ${ }^{2}$

Quer se tratasse da relação do médico com seus clientes, ou de sua relação com outros profissionais da área, daí emergia seu 'poder' e a conseqüente desumanização, assujeitamento e objetificação do doente que tal exercício implicava. Esse poder, que articula-se a um saber transmitido e reafirmado por meio da aprendizagem médica, ${ }^{3}$ era problemática central nas diversas perspectivas teóricas acerca do hospital e de seu funcionamento que marcaram as décadas de 1960 e 1970.

A questão, contudo, não é tão simples. Para que o médico atingisse tal lugar de poder foram necessárias transformações sociais que culminam na delegação dos cuidados de doentes e moribundos ao saber médico institucionalizado. Os posicionamentos críticos iniciais ao poder médico tornaram-se mais complexos nas duas últimas décadas, abrangendo um espectro mais amplo de questões. Por um lado, segundo alguns autores, o poder é exercido porque a sociedade o delega aos médicos e, por outro, a própria prática médica teria sido reorganizada para assumir tal delegação social.

Entre os autores que abordaram esse tema, destacam-se Philippe Ariès - $O$ Homem Diante da Morte (1981) - e Claudine Herzlich, em História da Morte no Ocidente (1975). Ariès centrou-se nas mudanças sociais diante da morte, suas representações coletivas e, conseqüentemente, do medo da doença. Focalizou a passagem do monopólio da família e dos religiosos para o médico e suas instituições, no que diz respeito aos cuidados de doentes e moribundos. Segundo o autor, desde o século XV, o horror à morte, à doença e à velhice já constituía inquietação dos poetas. Ao longo do tempo, operou-se uma fusão das representações coletivas 
da angústia da morte e do medo da doença. Com a mudança da estrutura e do sentimento de família, houve um deslocamento do lugar da morte: as famílias, saturadas afetivamente, não suportaram mais os encargos relativos aos cuidados de seus moribundos e passaram a delegá-los às instituições médicas, então fortalecidas e reorganizadas.

Assim é que o século XX assistiu a uma administração da morte na qual a medicina, por seus progressos técnicos, passou a ser responsável tanto pela eficácia e esperança de postergar a morte, como pelo seu ocultamento social. Os temores atuais ainda repousam sobre o aniquilamento social que a doença introduz no curso da vida, obrigando que a idéia da morte passe a ser vista como um fracasso do sistema de atenção médica. A morte é ocultada socialmente por meio de sua delegação ao médico e ao hospital, tornando-se medicalizada (Ariès, 1975).

Em La Soledad de los Moribundos e em O Processo Civilizador $(1994 \mathrm{e}$ 1997), Norbert Elias tratou pioneiramente do ocultamento da morte, considerando tal processo como parte do impulso civilizador iniciado nas sociedades européias, há cerca de quinhentos anos.

Em Os Encargos da Morte (1993a), a socióloga francesa Claudine Herzlich realiza uma revisão bibliográfica sobre o morrer no hospital, apontando o caráter recente da morte como objeto de estudos das ciências sociais. ${ }^{4}$ De acordo com a autora, a evolução das técnicas da medicina e das novas possibilidades de reanimação torna necessária uma redefinição da morte, bem como dos princípios éticos que regem a ação dos médicos. Aborda uma série de questões relativas à corporação e prática médicas - da evolução do saber às novas técnicas - produtoras da diminuição da mortalidade e do prolongamento do tempo de vida. Herzlich explicita o processo de medicalização da morte, da sua inscrição em regras e rotinas institucionais, que privilegiam a competência e a eficiência médicas. Para que os profissionais possam trabalhar é necessária a institucionalização da morte, racionalizando-a e rotinizando-a.

Herzlich cita, além dos de Ariès, três estudos pioneiros sobre a delegação social dos doentes e moribundos à instituição médica: Passing On: the social organization of dying (1967), de David Sudnow, e Awareness of Dying (1965) e Time for Dying (1968), de Barney Glaser \& Anselm Strauss. O primeiro é uma etnografia da morte, desenvolvida em dois hospitais que atendiam doentes pertencentes a distintos estratos sociais. Sudnow investigou os cuidados prestados pelas equipes de saúde aos moribundos, o modo como as famílias eram informadas da morte e como a organização social do hospital era afetada pelo óbito. $\mathrm{O}$ autor categorizou a 'morte social', que precede a morte biológica, quando a 
equipe percebia e tratava o doente - ainda vivo - como se já fosse um cadáver (Sudnow, 1967).

Já Glaser \& Strauss investigaram as práticas cotidianas em hospitais e as relações entre profissionais e pacientes, identificando uma trajetória do paciente no morrer, e uma estratégia defensiva da equipe de saúde em relação à morte. Cabe ainda apontar os estudos de Elizabeth Kübler-Ross, autora de On Death and Dying (1969), que centra-se no mesmo ponto que Glaser \& Strauss, investigando, contudo, somente o estado emocional dos pacientes. Tendo por seu trabalho clínico com doentes terminais, ela analisa os diferentes estágios por que passam psicologicamente antes da aceitação da própria morte.

Mais do que a constatação de que os cuidados dos doentes e moribundos são socialmente delegados à instituição médica e ao seu saber, essa literatura revela uma interessante análise da própria concepção medicalizada da morte. No hospital moderno, a morte não é mais um evento simples e sim como um fenômeno complexo, passível de ser decomposto analiticamente em morte clínica, biológica e celular. Assim, a morte deixou de ter uma fronteira clara, passando a ser um processo gradual e até, por vezes, reversível.

A definição da morte revela-se circular, ligada à ação do médico que, tanto pode decidir interromper os cuidados, como fazer esforços de reanimação. É, portanto, no mesmo momento em que se afirma um poder fantástico do médico que, sintomaticamente, surge também sua fragilidade. A reflexão sobre as terapêuticas heróicas colocou em questão o alcance do poder do médico, o limite das possibilidades técnicas e o caráter exclusivo de sua decisão, mais até do que a própria natureza da morte.

Buscando contribuir para essa tradição crítica, mas incorporando a crítica à crítica, a investigação centra-se no hospital, compreendido como local de delegação de cuidados e campo de exercício da competência do saber médico. Tratase de refletir de que forma, com quais tensões e consequiências se dá o exercício da prática médica. $\mathrm{O}$ estudo enfoca a tomada de decisões médicas referentes à doença, ao sofrimento, à vida e à morte dos pacientes. O processo decisório é tomado como ponto de convergência central da articulação das tensões relativas à delegação de cuidados à instituição hospitalar e das tensões constitutivas do próprio campo da prática dos profissionais da saúde.

Não se trata, portanto, de optar entre uma concepção humanitária e outra desumanizadora da prática médica. É preciso, sim, compreendê-la como constituída por uma dupla dimensão, que pode ser nomeada de diversas formas: 'competência-cuidado', 'objetividade-subjetividade', 'racionalidade-experiência', 'saber-sentir', 
entre outras. Não são pólos facilmente articuláveis. Ao mesmo tempo, são intrínsecos e inerentes à prática médica, conduzindo necessariamente a uma tensão compreendida por diversos autores como estruturante dessa mesma prática. ${ }^{5}$

Em pesquisa realizada com estudantes, na qual os temas do cuidado e da competência representam uma tensão cultural desenvolvida durante o período de aprendizado, Byron Good \& Mary-Jo Del-Vecchio Good (1993) colocaram em foco a dupla dimensão da medicina. Segundo os estudantes pesquisados, os médicos devem ser competentes e possuir qualidades no cuidar. A competência é associada à linguagem das ciências básicas, ao conhecimento, à técnica, ao fazer e à ação. O cuidar é expresso na linguagem dos valores, das relações, da compaixão e empatia, ou seja, o 'não-técnico'. Os autores associam a justaposição da competência e do cuidar a outros pares opostos, presentes na racionalidade científica ocidental: 'tecnologia-humanismo' e 'ciência-cultura'.

A medicina como instituição cultural ocidental, aceita e define tal dicotomia como essencial ao papel do médico, que deve dar completa primazia à competência, base presumida para sua prática. Contudo, só saber e competência não dão conta da abrangência da prática médica, pois a experiência, o sentir e a subjetividade do médico são extremamente relevantes para o êxito no atendimento ao doente. Octavio Bonet (2004), em Saber e Sentir: uma etnografia da aprendizagem da biomedicina, constatou a freqüente manifestação desses dois conjuntos de representações - o 'saber' e o 'sentir' - nas práticas cotidianas do serviço hospitalar. A biomedicina, fundada sobre uma construção dualista - da qual deriva a chamada tensão estruturante -, para se constituir como um saber 'científico' dividiu seu campo de prática em três totalidades: o médico, o paciente e a relação entre eles. É nessa biomedicina 'dualizante' que o estudante forma seu habitus ${ }^{6}$ médico e a ele adere, o que, por vezes, conduz a um conflito - mais ou menos consciente que pode chegar a um dilema ético de difícil solução. Desse modo, os médicos encontram-se, em sua prática, prisioneiros de um duplo vínculo: se o dualismo fundamental é afastado, todo o princípio básico da aprendizagem também o é, automaticamente. Paradoxalmente, os médicos, ao aceitarem a dupla inserção, advinda da tradição de seu aprendizado, envolvem-se necessariamente em um conflito que, justamente por sua característica estruturante, não tem escapatória.

A pesquisa desenvolvida no CTI, que dá origem a este livro, voltou-se a compreender como se produz, na prática cotidiana dos profissionais da saúde de uma unidade hospitalar muito específica, a tentativa de resolução da equação entre as duas dimensões constitutivas dessa mesma prática, diante de situações que envolvem decisões de vida, morte e sofrimento. O CTI tem grande importância 
no hospital, sendo quase um hospital dentro do hospital, uma unidade que concentra recursos tecnológicos e equipe altamente especializada, a serviço de doentes em situação crítica ou limite. Trata-se de um espaço social onde a dupla dimensão estruturante da prática médica - o cuidado e a competência - está criticamente implicada no processo decisório.

O fato de o hospital investigado ser também uma instituição voltada ao ensino é relevante, pois por intermédio da transmissão pedagógica do saber científico é possível apreender o modo de construção dos 'objetos' com os quais os médicos lidam, além dos valores, atitudes e habilidades consideradas necessárias à sua formação profissional. Desse modo, os médicos ocupam lugar central nesta pesquisa, dada a posição estratégica do seu saber e da sua competência para cuidar, tratar e curar. ${ }^{7}$

\section{Notas}

1 No Brasil também há uma produção sobre o hospital psiquiátrico, como Costa (1976) e Carrara (1998a).

2 Como respostas às críticas à desumanização do hospital e ao ocultamento e usurpação do indivíduo com referência à sua morte, surge recentemente a proposta dos Cuidados Paliativos (Menezes, 2004).

3 Sobre o tema, ver Merton, Reader \& Kendall (1969) e Becker (1992).

4 A produção de Claudine Herzlich é extensa e se destaca no campo sociológico francês referente à medicina, doença, carreiras e práticas dos médicos franceses.

5 Essa dupla dimensão também pode ser articulada à 'inarredável tensão' entre romantismo e racionalismo, segundo Duarte \& Leal (1998).

6 Conforme Pierre Bourdieu: habitus caracteriza o conjunto de usos e formas de práticas de um dado grupo social. Tende, portanto, a conformar e a orientar a ação, mas na medida em que é o produto de relações sociais ele tende a assegurar a reprodução dessas mesmas relações objetivas que o engendraram (Bourdieu, 1994: 15).

7 Como várias falas de profissionais contêm termos técnicos, para facilitar a leitura foi elaborado um Glossário, localizado ao final do livro. 



\section{1 \\ Entrando no CTI}

Tento relatar algo e, mal me calo, noto que ainda não disse nada. Uma maravilhosa substância luminosa, refratária, permanece em mim e escarnece das palavras. Será o idioma, que lá não compreen-

di e que agora deverá se traduzir lentamente dentro de mim? Lá existiram acontecimentos, imagens e sons, cujos significados só agora começam a se constituir para mim; que não foram captados nem delimitados por palavras; que estão além das palavras, que são mais profundos e mais prenhes de significado do que aquelas.

Sonho com um homem que tenha desaprendido os idiomas do mundo, que não entenda mais o que se diz em nenhuma parte da terra.

O que é a língua? O que ela esconde? O que nos rouba? (Canetti, 1987)

Ao decidir desenvolver pesquisa de campo em CTI, conversei com alguns amigos médicos sobre o projeto, pedindo-lhes sugestões. Os comentários causaram surpresa: a preocupação deles era, sobretudo, com minha integridade física. Fui aconselhada por um destes médicos a vacinar-me contra hepatite tipo B, antes da primeira visita ao serviço. Outro disse: "não se aproxime muito dos leitos, pode espirrar sangue em você...". A imagem era o risco de contaminação e, por isso, seria aconselhável reforçar minhas defesas. Parecia que partia em viagem para uma selva muito perigosa.

A observação etnográfica no CTI iniciou-se em 2 de fevereiro de 1999, com autorização oficial das chefias do hospital e da unidade. Freqüentei o serviço durante três meses, em 26 visitas, totalizando cerca de cem horas, conhecendo as equipes de todos os sete dias da semana. Não realizou-se observação à noite nem de madrugada, mas em diferentes períodos do dia, de forma a captar o ritmo de trabalho. 
Segundo Bronislaw Malinowski (1980), a observação participante coleta dados por meio da imersão do pesquisador na vida cotidiana do grupo social que investiga. Foi o que se buscou durante a investigação, ao freqüentar todos os espaços do setor, sempre com roupa 'mundana', por não ter sido solicitado o uso de vestimenta especial.

Na primeira observação, quase todos os profissionais já tinham notícia da presença de uma pesquisadora. A chefia médica havia informado à equipe sobre o projeto. Houve uma receptividade inicial positiva. Aos poucos, os profissionais começaram a questionar o intuito da observação. À medida que ficava claro que a pesquisadora era uma mestranda, com propósito de estudo, os profissionais ficavam mais relaxados. Apenas aparentemente, pois alguns não pareciam se comportar com espontaneidade, o que um médico confirmou:

Eu acho que só daqui a um tempo você vai poder realmente saber como é, porque muita gente não vai agir naturalmente com você aqui. Depois de algum tempo as pessoas vão voltar a agir naturalmente, quando se esquecerem da sua presença... (médico plantonista)

De fato isso ocorreu. No período inicial da observação, um médico resolveu, apenas para ilustrar o procedimento, fazer a reunião com os familiares sem a presença da psicóloga, geralmente a coordenadora do evento. Com o transcurso da observação, os profissionais passaram a agir mais naturalmente. Entretanto, ao mesmo tempo em que havia uma preocupação da equipe em 'passar' a melhor imagem, as fantasias sobre a investigação surgiam. Ao ser apresentada a outro médico por um plantonista, este disse: "aqui tem de tudo, tem até mestranda de num sei de quê, que é o FBI..." Isso foi dito em tom de brincadeira e sorrisos, mas a idéia era clara: não se tratava de um estudo e sim de controle e espionagem.

O diário de campo também foi objeto da curiosidade dos profissionais. Alguns pediram para vê-lo, "mas só prá ver se você anotou direitinho..." e, dito por um médico-residente, "Ih, você sempre fazendo anotações, deve estar fazendo um estudo psiquiátrico de todos aqui, cada um mais louco...". A fantasia era que 'a loucura dos profissionais' poderia ser ali captada. Um médico plantonista disse, brincando: "vou até a Psiquiatria pegar haldol, volto logo". Fez perguntas sobre a especialização médica da pesquisadora e o objetivo do estudo. Ao ouvir as respostas, disse: "Ih, agora estou ferrado, ela vai achar que sou louco porque fui na Psiquiatria...". Tais comentários foram feitos sem o conhecimento da especialização em Psiquiatria da autora, pois a maior parte dos profissionais sabia apenas que cursava o mestrado em medicina social. Somente após certo tempo de observação, alguns membros da equipe souberam da formação como psiquiatra e psicanalista. 
O fato de a pesquisadora ser médica podia dar margem a duas situações distintas: tanto poderia aproximá-la dos colegas como, eventualmente, fazer com que alguns se sentissem julgados tecnicamente. Depois de várias idas ao campo, um médico plantonista perguntou: "Afinal de contas, o que você quer estudar aqui no CTI?" Após tomar conhecimento do título do projeto disse, rindo: "Ah, então você está aqui pra estudar a minha competência médica, a competência do Dr. Fulano!".

A presença de uma observadora parecia ameaçar especialmente alguns profissionais mais jovens, como, por exemplo, um residente que disse certa vez, dirigindo-se a um estagiário (ambos de medicina): "Cuidado com o que diz perto dela, ela anota tudo, depois vai sair escrito que o Fulano de Tal disse isto e aquilo". Reafirmou-se então o compromisso com a chefia do CTI acerca da não identificação do hospital e de seus integrantes.

Os contatos com as equipes se deram de maneiras distintas: os membros da equipe de enfermagem (enfermeiros e auxiliares de enfermagem) mostravamse mais contidos, em uma postura inicialmente submissa. Colocavam-se à disposição para o que fosse preciso, ofereciam ajuda e esclarecimentos mas, quando a pesquisadora aproximava-se da equipe médica, os enfermeiros se afastavam - um dos primeiros indícios das tensões entre as duas categorias profissionais.

No final do período de observação, alguns enfermeiros e auxiliares já se comportavam com maior espontaneidade, em relação à presença da pesquisadora no setor. Em uma ocasião, à despedida, alguns auxiliares de enfermagem disseram: "Vai com Deus", "Volte logo, você vem na segunda-feira?", "Tudo de bom pra você, bom descanso". Essas mesmas expressões eram usuais nas despedidas com seus colegas e com a equipe de fisioterapia, mas não no contato com os médicos.

Com a frequiência das observações houve maior aceitação e a pesquisadora passou a ser vista, pela equipe, como colega. Algumas vezes em que observei a execução de 'procedimentos' nos corpos dos doentes, o estagiário de medicina solicitou ajuda para abrir um frasco ou pacote. Apenas em uma ocasião uma auxiliar de enfermagem fez o mesmo tipo de solicitação: ela estava de luvas e pediu que arregaçasse as mangas do seu avental. Nenhum membro da equipe de fisioterapia fez demanda semelhante durante todo o período de observação.

Após certo tempo de frequiência à unidade, alguns médicos de outros setores do hospital passaram a cumprimentar a pesquisadora como se fizesse parte da equipe do CTI. Em certa ocasião um médico disse: "Você não estava no plantão de domingo? Te vi com a Fulana, plantonista, sei que você veio e está aqui de novo...”. E passou a contar sobre sua vida e plantões. Esse episódio é indicativo de uma inclusão da pesquisadora no CTI, talvez uma forma da equipe 'domesticar' a 
presença de um intruso, afastando a ameaça de uma 'espiã', o que chegou a ser explicitado por uma profissional:

Em certo momento me senti perseguida pela presença de uma observadora, e imaginei que todos devem se sentir assim. Mas, depois, pensei que você está aqui pra escrever um trabalho, para pensar o CTI, que então é mais uma pessoa para colaborar conosco. (psicóloga)

Em outra ocasião, ao chegar, o plantonista me cumprimentou dizendo: "Já estava com saudades, há quanto tempo você não aparece aqui”. Ao ser considerada como colega, o diálogo fluía mais facilmente: em certa ocasião, fui abordada por uma enfermeira interessada no tema da pesquisa, por pretender fazer mestrado sobre o cuidado humano.

Segundo Malinowski (1980), a pesquisa de campo deve ser desenvolvida em três níveis denominados figurativamente como 'esqueleto', 'carne/sangue' e 'espírito' de determinado grupo social. O primeiro seria constituído por fatos relativos à organização da 'tribo' ou à 'anatomia' de sua cultura. O seguinte, pelos imponderáveis da vida real, coletados por meio de observações minuciosas e detalhadas sobre o modo pelo qual os 'nativos' vivem ou atualizam as normas ou regras formais. Finalmente, o terceiro nível seria constituído pelo modo como o grupo pensa suas práticas: "Estas três linhas de abordagem conduzem ao objetivo final que o etnógrafo nunca deve perder de vista. Este objetivo é, resumidamente, apreender o ponto de vista do nativo, sua relação com a vida, compreender sua visão do seu mundo" (Malinowski, 1980: 60).

Do mesmo modo como os profissionais percebiam minha presença de distintas formas - ora como familiar, ora como exótica - eu também oscilava. Em muitos momentos, por minha formação médica, sentia-me em ambiente familiar enquanto em outras situações era uma estranha, muito distante daquele universo. Uma das mais tradicionais premissas das ciências sociais é a necessidade de uma distância mínima que garanta ao pesquisador condições de certa objetividade em seu trabalho. É inevitável e imprescindível, entretanto, um envolvimento com o objeto de estudo, o que necessariamente conduz à idéia de movimentos sucessivos de distanciamento e aproximação (Velho, 1981).

Vestir a capa de etnólogo é aprender a realizar uma tarefa, que pode ser contida em duas fórmulas: "transformar o exótico em familiar e/ou transformar o familiar em exótico" (DaMatta, 1978: 28). A familiaridade representa um certo tipo de apreensão da realidade, que conforma o conhecimento da vida social de uma época e de um grupo. Assim, ao estudar o que está próximo, o antropólogo 
expõe-se, com maior ou menor intensidade, a confrontos com outros especialistas ou mesmo com leigos, que podem discordar das interpretações do investigador (Velho, 1981).

Após algum tempo de freqüência no CTI, dei-me conta de estar presa de anthropological blues, expressão cunhada por Roberto DaMatta (1978), ao se referir ao envolvimento do pesquisador para além do contexto da observação. $\mathrm{O}$ setor passava a me preocupar de uma forma especial. Fora do CTI, pensava nos pacientes - se teriam melhorado ou não - ou se determinados materiais e medicamentos escassos no hospital já estariam disponíveis. Em certa ocasião, me emocionei com o anúncio dado por uma médica à mãe de uma paciente jovem, sobre a proximidade de sua morte. Como diz DaMatta, parafraseando Lévi-Strauss, o sentimento e a emoção seriam "os hóspedes não convidados da situação etnográfica" (DaMatta, 1978: 30).

O surgimento de emoções na pesquisa de campo, obriga a refletir sobre a posição de observadora e sobre as formas de envolvimento emocional dos profissionais da saúde que trabalham no CTI. Assim como o profissional de CTI necessita de certa distância de seus pacientes, o pesquisador também deve saber afastar-se do seu objeto de investigação. Há, pois, um paradoxo na situação etnográfica: "Para descobrir é preciso relacionar-se e, no momento mesmo da descoberta, o etnólogo é remetido para o seu mundo e, deste modo, isola-se novamente" (DaMatta, 1978: 32).

Além da observação direta, buscou-se apreender as interpretações dos profissionais sobre os eventos do setor - o 'espírito' do grupo -, conversando com eles e participando de suas conversas. Após cerca de dois meses de frequiência, entrevistas gravadas foram realizadas com dez profissionais: três médicos staff, ${ }^{1}$ um médico-residente, um estagiário de medicina, uma psicóloga, uma enfermeira, dois auxiliares de enfermagem, um residente de fisioterapia. A maior dificuldade em sua execução foi a disponibilidade, pois os profissionais diziam não ter tempo fora do CTI. Elas ocorreram sempre no horário de trabalho, o que fazia com que fossem interrompidas em diversas oportunidades. Apenas um profissional negouse a conceder entrevista. Todos disseram ter gostado muito da conversa, dando a impressão de que tinham muito a falar, talvez por haver pouco espaço para reflexões na prática do CTI.

A principal característica da entrevista é ser um 'fato de palavra', no qual o poder expressivo da linguagem verbal pode alcançar descrições, explicações, justificativas e avaliações sobre uma série de questões, que se impõem quando se deseja abordar certos temas (Hammersley \& Atkinson, 1986). A realização de uma 
entrevista pode ser comparada a uma arte, por ser um instrumento flexível, não obedecendo a regras técnicas muito estritas. A qualidade da interação entrevistador/ entrevistado é que vai decidir o desenrolar da entrevista, um encontro. Entreter-se com alguém é uma experiência singular que não pode ser conduzida, codificada, estandardizada ou profissionalizada. Trata-se de uma situação que comporta sempre uma possibilidade de pontos desconhecidos - portanto, de riscos - inerentes ao fato de ser um processo interlocutório e não simplesmente um levantamento de informações (Blanchet \& Gotman, 1992). Como o habitus, a entrevista é um tipo de 'improvisação regrada'. Improvisação porque cada entrevista é uma situação singular, suscetível de produzir efeitos de conhecimento particular. Regrada porque para produzir tais efeitos de conhecimento, a entrevista demanda um certo número de ajustamentos que constituem propriamente sua técnica.

A entrevista pode ser definida como um percurso ou uma via de acesso: não se reduz a uma manipulação técnica, nem a um encontro social rotineiro (Blanchet \& Gotman, 1992). Assim, elegeu-se a entrevista como instrumento privilegiado para a compreensão dos fatos observados concernentes às práticas sociais e à produção de discursos sobre estas.

Para captar o que Malinowski nomeou de "esqueleto, carne e sangue, e espírito", foi necessária uma imersão - provavelmente com consequiências tanto para o próprio serviço investigado como para o pesquisador. Na observação, foram apreendidas as práticas e a lógica de um grupo profissional. A partir da visão e da escuta dos atores observados, é construída uma versão - a do pesquisador -, dentre tantas outras possíveis.

\section{Notas}

1 O termo staff refere-se ao profissional que possui estabilidade, em geral concursado e ocupando posição hierárquica superior aos profissionais trabalhando em contrato temporário. 


\section{2 \\ Abolição do Tempo}

Acordei. De um lado, um caninho com um líquido amarelo que entrava em minha veia; do outro, um com sangue. $\mathrm{Na}$ boca, um acoplado, aqueles aparelhinhos de respiração artificial que já conhecia do Fantástico. Muito eficiente, fechava a boca com a língua, mesmo assim o ar entrava. Tinha uma sanfoninha pendurada que enchia e esvaziava.

Assoprava e ela nem se tocava, enchia e esvaziava...

Fiquei curtindo o bicho: como é gostoso respirar sem fazer força, enchia e esvaziava... Passei a reparar no ambiente. Era uma sala pequena, com luz fria. Não sabia se era dia ou noite, porque não havia janelas, só paredes brancas. À minha esquerda, um leito com um cara em cima. Também tinha uma sanfoninha. À direita, dois leitos. Tentei me erguer, mas não consegui.

(Paiva, 1983)

\section{Da Pólio à Sofisticação Tecnológica}

O Centro (ou Unidade) de Tratamento Intensivo surgiu nos Estados Unidos, entre 1946 e 1948, a partir da epidemia de poliomielite e do início do uso dos respiradores artificiais na busca da manutenção da vida desses doentes (Simão, 1976). Na Dinamarca, Suécia e França, os médicos utilizaram simultaneamente os respiradores artificiais e montaram unidades especiais para pacientes com pólio. Além dos infectados por esta epidemia, os primeiros pacientes que demandaram tratamento intensivo nos Estados Unidos foram os soldados feridos na Segunda Grande Guerra e na guerra da Coréia. Pesquisadores ingleses e americanos concluíram, ao fim da década de 60, que os gravemente enfermos tinham problemas 
fisiopatológicos comuns e que suas sobrevidas dependiam do controle de uma série de funções corporais (Civetta, Taylor \& Kirby, 1988). Várias tentativas foram feitas para a organização dos CTIs, mas somente com o desenvolvimento de certos equipamentos e terapêuticas tornou-se possível a concretização das unidades de tratamento intensivo. A partir de então, a UTI se desenvolveu e gerou outras unidades específicas: Unidade de Choque, Unidade Coronariana, Unidade Respiratória, Unidade de Diálise Renal, Unidade Intensiva Neo-Natal etc. Essa linha de segmentação e de ultra-especialização mantém-se no mundo, particularmente nos Estados Unidos, apesar das críticas relativas ao divisionismo dos diversos órgãos oficiais dedicados à administração hospitalar (Simão, 1976: 6).

No Brasil, esse tipo de serviço surge na década de 60, em hospitais de grande porte do Sul e Sudeste do país. Presentemente, o CTI encontra-se no centro de um debate da classe médica e do órgão de representação da classe - o Conselho Federal de Medicina (Jornal do Cremerj, setembro de 1998: 17). ${ }^{1}$ A proposta de regulamentação da atividade do médico intensivista como especialista é discutida, bem como a regulamentação das UTIs no país. A medicina intensiva ainda não é oficialmente considerada uma especialidade no Brasil, havendo uma demanda, por parte dos profissionais, por sua regulamentação.

Em resumo, o CTI foi criado e mantém-se com o objetivo de concentrar três componentes críticos: os doentes mais graves, o equipamento técnico mais caro e sofisticado e a equipe com conhecimento e experiência para cuidar desses pacientes e lidar com essa aparelhagem específica (Civetta, Taylor \& Kirby, 1988).

\section{"Queu Está aqu Dentro Não Vê o SoL"}

O Centro de Tratamento Intensivo escolhido para a observação pertence a um hospital público universitário, localizado na Zona Norte da cidade do Rio de Janeiro. O hospital possui cerca de quinhentos leitos para internação e não oferece atendimento de emergência, apenas ambulatorial. O CTI localiza-se no penúltimo andar do hospital, ao lado de uma Unidade Coronariana e próximo ao Centro Cirúrgico. Há uma porta que dá acesso a um corredor comum ao Centro de Tratamento Intensivo Geral e à Unidade Coronariana. O corredor funciona como 'sala de espera' para os familiares dos doentes internados em ambas as unidades. Nesse local há um aparelho de vídeo e uma televisão. Instalados há certo tempo, são uma espécie de símbolo das diretrizes modernas do setor. Eles são utilizados 
para projeção de um vídeo explicativo, elaborado pela psicóloga e pelas equipes de medicina e enfermagem, direcionado aos familiares dos pacientes internados. O vídeo contém explicações sobre o funcionamento do CTI, sua aparelhagem e sobre os cuidados a serem tomados pelos visitantes, como lavar as mãos antes e após o contato com os doentes. Há também instruções incentivando o familiar a tocar e estimular seu parente enfermo, para que ele receba carinho e ânimo no enfrentamento da doença e assim deseje viver. Além do vídeo, os familiares recebem um folheto denominado Manual do Centro de Tratamento Intensivo, com os telefones do serviço e explicações sobre os aparelhos utilizados e o vocabulário da equipe.

Portanto, o primeiro contato com o CTI está marcado pela apresentação das regras e normas de funcionamento a que o visitante deve atender. Um equipamento eletrônico faz às vezes de intermediário, o que indica o lugar e a importância da tecnologia no setor. $\mathrm{O}$ vídeo explicativo aponta a preocupação com as relações das famílias dos internados, tanto com seus doentes como com o CTI, as máquinas e a equipe. Trata-se de uma unidade que mobiliza recursos modernos para sua humanização, o que, segundo os informantes, a destaca de outros CTIs de hospitais públicos e privados.

Quando se passa pela porta de entrada do CTI há um pequeno corredor que dá acesso a duas outras portas: uma, à esquerda, para um quarto com um leito para isolamento de paciente e outra para uma sala de reuniões. Tanto o quarto quanto a sala têm grandes janelas de vidro para o interior do CTI, permitindo a visão do movimento de entradas e saídas do setor. A sala de reuniões foi o primeiro local para o qual me dirigi ao encontro da equipe médica. Quando algum de seus membros não está ocupado examinando doentes, provavelmente encontrase nesse ambiente, em torno da mesa de reunião. Os profissionais das outras equipes se referem ao local como 'sala dos médicos', uma indicação inicial da divisão socioprofissional dos espaços. Esse ambiente é o palco onde se desenrolam as tramas que conduzem às decisões médicas, sendo estas executadas no espaço contíguo, o 'salão' do CTI.

Prosseguindo-se pelo corredor inicial chega-se ao ‘salão', o maior ambiente do setor, constituído por um grande espaço semicircular, com seis leitos dispostos ao redor do posto de enfermagem. Pelo fato do posto de enfermagem estar situado em um nível superior do restante do 'salão' (dois degraus acima), quem ali está tem visão total do que ocorre em todos os leitos (inclusive o do isolamento, através da janela de vidro). Os leitos estão dispostos com as cabeceiras encostadas nas paredes e os pés voltados para o interior do semicírculo, separados por divisórias móveis. Na cabeceira de cada um deles há uma grande quantidade de 
aparelhos, ${ }^{2}$ e ao lado um carrinho com materiais, como gaze, álcool etc. Por trás do posto de enfermagem, há uma parede com pias e armários para medicações e materiais. Há também duas pias próximas aos leitos. Diversos cartazes instruem os profissionais e visitantes a lavarem as mãos antes e após o contato com os doentes. No decorrer do período de observação, alguns aparelhos foram acrescentados ao ambiente: um equipamento de som e várias televisões, destinados aos pacientes e aos médicos.

No 'salão', além dos pacientes, encontram-se as equipes de enfermagem, de fisioterapia, de faxina e médica. $\mathrm{O}$ formato desse espaço segue as normas recomendadas internacionalmente para a construção de unidades de terapia intensiva. Trata-se de uma planta semelhante à estrutura do Panóptico de Bentham (Foucault, 1979): uma organização com máxima visibilidade do ponto central, possibilitando maior controle e vigilância permanente, funções exercidas principalmente pela equipe de enfermagem.

À direita e à esquerda do posto de enfermagem, por trás da parede com armários, há um corredor com várias salas: uma para limpeza do material utilizado, copa, sala da chefia da enfermagem, quarto de repouso dos médicos e fisioterapeutas, quarto de repouso da enfermagem ${ }^{3}$ e um depósito de materiais e medicação.

O ambiente do Centro de Tratamento Intensivo causa, em quem ali entra pela primeira vez, uma série de impactos sensoriais: sonoros, olfativos, visuais. Muitos ruídos - que vão desde as vozes dos profissionais até os sons da aparelhagem, com seus vários alarmes, além das campainhas dos telefones do serviço, dos inúmeros celulares e pagers dos profissionais e do aparelho de som - preenchem o local. ${ }^{4}$ Há uma cacofonia de sirenes e alarmes. O segundo impacto é olfativo, pois há um odor característico no 'salão', uma mistura de cheiros de desinfetante, de medicações, de materiais para curativos e de secreções dos doentes. A combinação é enjoativa e variável, com alternância de um ou de outro tipo de cheiro. $\mathrm{O}$ ambiente é muito claro, iluminado artificialmente por luz fluorescente, com as janelas sempre fechadas, cobertas com um filtro, de forma que não é possível a visão da luz do dia. Há uma série de cartazes proibindo a abertura das janelas para evitar a entrada de insetos. Apesar da existência de oito relógios de parede no CTI, durante todo o período de observação só me dei conta do que está na sala de reuniões. ${ }^{5}$ Em todos os ambientes a temperatura é geralmente fria e mantida constante por condicionador de ar central. $\mathrm{O}$ isolamento do mundo exterior faz com que o CTI seja um local onde há quase uma total abolição do tempo.

Em geral, são considerados para internação em CTI os casos avaliados como 'viáveis', com possibilidade terapêutica. Os doentes internados vêm, em 
sua maior parte, das enfermarias do hospital e são portadores de doenças crônicas em situação de agravamento, como patologias respiratórias e auto-imunes. Exatamente por isso, a duração da internação nesse setor é considerada muito maior do que em CTIs de outros hospitais. É especialmente maior do que em CTIs de hospitais que têm atendimento de emergência. No dizer de um médico plantonista: "quando uma pessoa sofre um acidente, em geral ela está com os sistemas equilibrados. É mais fácil tratar do que um doente que já vem desequilibrado cronicamente da enfermaria". Alguns pacientes vêm somente para acompanhamento pós-cirúrgico, quando uma vigilância maior é necessária, sendo menor seu tempo de internação.

Os pacientes internados no CTI permanecem deitados, pessoas imóveis, aparentemente dormindo, com fios e tubos conectados a seus corpos. A maior parte respira por aparelhos. Assemelhavam-se, por vezes, a corpos inanimados. Os doentes são muito manipulados pelos profissionais: exames físicos, coleta de sangue, radiografias, além de exercícios musculares e respiratórios. Algumas vezes os profissionais tocam os corpos dos doentes sem dirigir a palavra a eles. Em geral, os pacientes têm seus corpos cobertos, exceto quando examinados ou no banho no leito, efetuado pela equipe de enfermagem. A exposição da nudez é cercada de cuidados. Para evitá-la são colocados biombos na frente dos leitos durante o banho, execução de curativos e outros procedimentos higiênicos.

O controle e a vigilância são essenciais para o bom funcionamento do CTI e, talvez por isso, as atividades ali desenvolvidas sejam tão absorventes. Por vezes, eu mesma ficava completamente envolvida com tudo o que ali se passava, não me dando conta de que já tinham se passado várias horas e de que havia ultrapassado o horário em que planejava sair. Há relatos de pessoas que estiveram internadas em CTIs, como o de Marta Allué: "Os pacientes internados em Unidades de Cuidados Intensivos, onde a atividade constante e unilinear são acentuadas, costumam perder a noção do tempo e do espaço. Passei por esta provação no princípio" (Allué, 1998: 44).

O ambiente é construído de forma a isolar não apenas os doentes do ambiente externo, como também os profissionais que ali atuam. Isso parece ser mais perceptível pelos profissionais recém-chegados. Um estagiário de medicina, com cerca de três meses de freqüência ao serviço, disse em entrevista:

Quem está aqui dentro não vê o sol, não sabe se é dia ou noite. Uma tristeza não ver o sol. Imagine você ficar numa sala com a luz ligada o dia inteiro. Você olha o relógio e só assim sabe se agora é dia ou noite. Agora mesmo saí lá fora e vi que choveu de manhã. Está um pouco molhado lá fora, deu uma garoa. Eu estava aqui e nem vi . . (estagiário de medicina) 
É interessante como essa fala indica tanto a percepção do isolamento dos doentes quanto a dos profissionais que ali trabalham.

\section{A Rotina: UM RITMO INTENSO}

É no ambiente anteriormente descrito que circulam cerca de cem profissionais por mês, trabalhando por plantões. Um profissional só sai quando seu colega chega para substituí-lo. A unidade funciona 24 horas, ininterruptamente, contando com o trabalho das seguintes categorias profissionais: médicos, estudantes de medicina, enfermeiros, auxiliares de enfermagem, fisioterapeutas, estudantes de fisioterapia, psicóloga, faxineiros, secretárias, nutricionista e assistente social. ${ }^{6}$ Uma equipe multiprofissional tão completa, incluindo psicóloga e fisioterapeuta (inclusive com plantão noturno) é uma indicação do caráter inovador e abrangente da proposta desse CTI, já que, segundo os informantes, vários CTIs de hospitais privados e públicos no Rio de Janeiro não contam com uma equipe tão ampla. Essa grande quantidade de pessoal qualificado direciona o trabalho para a assistência intensiva a, no máximo, sete doentes extremamente graves. Para cuidar desses pacientes as equipes são organizadas em turnos e possuem uma série de tarefas de rotina, além das que surgem de acordo com as alterações apresentadas pelos internados.

Há flutuações no ritmo de funcionamento e no número de profissionais de acordo com o período ou o dia da semana. Nos dias úteis, durante as 12 horas do dia, o CTI funciona a todo vapor, com cerca de trinta profissionais. À noite, bem como nos finais de semana e feriados, o número é reduzido para dez, tornando o ambiente muito mais calmo e tranqüilo. Muitas vezes algumas pessoas preferem trabalhar nesses dias, como disse em entrevista uma auxiliar de enfermagem:

É muita barulheira, a quantidade de alarmes e de pessoas que tem aqui. Durante a semana tem mais de trinta pessoas dentro dessa terapia intensiva. Aqui o que mais incomoda é o barulho. Eu, quando tenho folga pra tirar, tiro durante a semana, nunca tiro no final de semana. (auxiliar de enfermagem)

Nem todos os profissionais percebem ou se incomodam igualmente com a diferença do ritmo de funcionamento do CTI. O barulho e a quantidade de pessoas circulando no serviço são mais notados pela equipe de enfermagem, talvez porque o local onde acontece a maior movimentação, o 'salão', seja exatamente o seu espaço de atuação. 
A rotina diária se inicia às sete horas da manhã, com a chegada da nova equipe de enfermagem, que 'recebe' o plantão da equipe anterior, sob a forma de informes detalhados sobre o estado de saúde de cada paciente. As equipes de medicina e fisioterapia também fazem o mesmo tipo de 'passagem' do plantão, com informações aos colegas de sua área. A partir de então, já com um número consideravelmente maior de profissionais do que à noite, o setor começa suas atividades. Os médicos e estagiários fazem os exames físicos dos pacientes, verificam as funções dos órgãos e colhem materiais para exames (como sangue ou secreções). Os enfermeiros e auxiliares de enfermagem verificam os sinais vitais dos doentes, fazem seus curativos e higiene, organizam os pedidos de medicamentos e preparam as medicações. Os fisioterapeutas executam exercícios respiratórios e musculares. Todos os profissionais, após os exames, registram suas observações em pastas separadas por categoria profissional. Tal atividade movimenta intensamente todos os espaços e, muitas vezes, mal há lugar para circulação das pessoas, umas esbarrando nas outras. Há vários profissionais em torno dos leitos e, às vezes, um precisa esperar que o outro termine seu exame para iniciar sua atividade.

Durante os períodos de observação permaneci muitas vezes no 'salão' e, em geral, no horário de 'engarrafamento' - termo dos profissionais para o período da manhã - ficava ora no posto de enfermagem, ora na sala de reuniões. Nesse período o barulho aumenta no ambiente. Conversas em voz alta, os telefones (do CTI e dos celulares) que tocam constantemente e, à medida que os profissionais manipulam os pacientes e as máquinas a eles acopladas, os alarmes destas que disparam. ${ }^{7}$ Muitas vezes, estagiários ou profissionais recém-formados, ao examinarem um doente, provocam o disparo desses alarmes e não o conseguem desligar, por falta de conhecimento prévio. Dependem da ajuda de um colega mais experiente para a interrupção do ruído. Os sons preenchem totalmente o espaço do 'salão'. Nos fins de semana e feriados, com a redução do número de pessoas, o ruído é menos intenso. De qualquer forma, a manhã é o período do dia mais movimentado e ruidoso. Quem trabalha ali há mais tempo não parece se dar conta do ruído, à exceção da equipe de enfermagem. Os profissionais recém-chegados ao serviço estranham. Uma residente de fisioterapia comentou, certa vez, que "parece até uma feira ou que está havendo um coquetel" ou, como disse um estagiário de medicina, "esses barulhos, isso incomoda demais, toda hora toca um monitor".

Terminados os exames e as tarefas de rotina, os profissionais fazem seus registros. A equipe de enfermagem permanece em seu posto, enquanto os médicos e fisioterapeutas se dirigem à sala de reuniões para fazer anotações e confrontá-las 
com os dados registrados pelas equipes anteriores. Aos poucos, a sala de reuniões fica repleta. Muitas vezes há mais de dez pessoas ali, sentadas ou em pé, conversando ou estudando em silêncio. Nessa sala há uma grande mesa retangular com cadeiras dispostas ao seu redor e estantes destinadas a livros, fichários, arquivos, radiografias e às bolsas e pastas dos médicos, além de um aparelho de televisão e um retroprojetor. Um grande quadro afixado na parede é atualizado a cada turno, sendo sempre lido por quem chega ao plantão. Nesse quadro estão anotados os números dos leitos com os nomes dos pacientes internados, data da internação, idade, peso, número de matrícula no hospital, diagnóstico, programação terapêutica e o médico responsável por cada leito no turno. Nele há também um espaço onde são anotados os pedidos de internação no CTI. Durante a observação, tais pedidos chegaram a alcançar, simultaneamente, o número de dez e nunca foram inferiores a dois. $\mathrm{O}$ relógio do serviço está situado acima do quadro, e em outra parede há um negatoscópio e um sofá. Essa sala é um ambiente com pouco espaço para circulação, com muitos móveis e objetos, embora não necessariamente desorganizado.

Por volta da metade da manhã, esse ambiente fica muito movimentado, com estagiários avaliando Raios $\mathrm{X}$, anotando relatos, preenchendo pedidos de exames ou pesquisando sobre alguma patologia em livros. Muitas vezes os profissionais mais experientes ensinam e tiram dúvidas dos iniciantes.

Em torno das 11 horas, há uma reunião nessa sala, denominada 'visita', coordenada pela médica responsável pela rotina, com a presença de todos os médicos e estagiários de medicina, um enfermeiro, um fisioterapeuta e a psicóloga. ${ }^{8}$ A sala de reuniões e a mesa então ficam lotadas de pessoas, pastas e prontuários e freqüentemente não há lugar para sentar. O médico-residente ou o estagiário responsável por cada leito faz um relato detalhado sobre 'seu' paciente desde a história da internação, evolução, até o exame físico e as dosagens do dia. Essa rotina é seguida a cada reunião, de forma que a história é repetida e há um acréscimo de informação diário. Procede-se a uma avaliação e discussão sobre o estado do paciente e as decisões são tomadas: pedidos de exames, pareceres de outros serviços do hospital ou alterações de medicamentos. Essas decisões são registradas por um médico-residente, pelo enfermeiro e pelo fisioterapeuta. $\mathrm{O}$ monopólio da fala é da equipe médica. Os outros profissionais são solicitados a prestar esclarecimentos somente em algumas ocasiões. Muito raramente os enfermeiros, fisioterapeutas ou a psicóloga interferem nas discussões. A hierarquia das profissões transparece na reunião: o médico staff rege as decisões e os outros profissionais registram as tarefas a serem feitas. Esse é um momento de central importância no funcionamento do serviço: "Você sabe que esta mesa é um local 
muito importante aqui? Aqui se estuda, se discute, se briga, se brinca, se come, é um lugar especial, é o centro do CTI. Se você quer saber as coisas é importante estar por aqui (médico plantonista).

De fato, a 'visita' é uma reunião de importância central no CTI. Ao redor de uma mesa - também central - as informações são passadas, os casos são discutidos e tomadas as decisões concernentes à vida e morte dos doentes. A ocorrência desse tipo de reunião multiprofissional diariamente (em dias úteis) é, de acordo com os profissionais entrevistados, mais um indicador da qualidade desse CTI e da abrangência de sua proposta terapêutica. Segundo os informantes, a maior parte dos CTIs de outros hospitais reúne-se somente duas vezes por semana.

O clima da 'visita' varia muito, de acordo com as situações e com os médicos presentes: há dias em que surgem brincadeiras, trocadilhos e risadas. Em outros, há discussões acirradas, discordâncias ou grandes silêncios. O constante é, entretanto, um tipo de relato cujo sentido, para os não-iniciados, é bastante hermético:

Senhor João, do leito três, com 78 anos, no quarto dia de CTI, com pneumonia comunitária grave, está com ventilação mecânica. Tem Cor Pulmonale e Dpoc. Isquemia de parede antero-septal. Está tomando Tridil. No eletrocardiograma de hoje há uma melhora. Está sedado. Tem uma boa gasometria, está compensado. TAP em queda, a albumina está caindo. Está bem edemaciado. A gente pretende dar mais albumina $e$ Lasix, e vitamina $K$ e suspender a Heparina. (médico-residente)

A linguagem utilizada é muito específica, soa como um código. Por vezes as anotações no quadro também são em código, como: "paciente com HAS, DM, IAM, foi feita EDA e programada TC".

Quando termina a 'visita', por volta das 13 horas, todos vão tomar as providências acertadas e a escala para o almoço é organizada. Muitas vezes, os profissionais fazem as refeições no serviço, encomendando 'quentinhas' ou encarregando um colega de comprar sanduíches para o grupo. Há dias em que não há tempo para refeições - o que, sem dúvida, é sinal da abnegação da equipe e do compromisso com o trabalho ali desenvolvido.

O ambiente torna-se então mais calmo e silencioso, com um menor número de pessoas circulando. Após o almoço, certos procedimentos são feitos, como retirada de sangue e punções; a seguir, os leitos são preparados para a visita dos familiares dos pacientes, diariamente, das 15 às 16 horas. A visita dos familiares é limitada oficialmente a, no máximo, quatro pessoas, sendo uma por vez. No entanto, de acordo com a situação, há exceções decididas pelas chefias médica e de 
enfermagem. Há grande preocupação em poupar os familiares, de modo que não são feitas manipulações - muitas vezes envolvendo retirada de sangue - durante esse horário. Nesse período, as equipes de fisioterapia e de medicina costumam ficar no quarto de repouso ou na sala de reuniões. A equipe de enfermagem permanece em seu posto e a psicóloga acompanha os familiares.

Às 16 horas, com o término da visita, os familiares se reúnem com um médico e a psicóloga para esclarecimento da condição dos doentes. A psicóloga está presente no horário de visita duas vezes por semana dando apoio aos familiares e participando da reunião com os parentes. Nos dias em que ela não está, a reunião é coordenada pelo médico plantonista e as orientações ficam a cargo da enfermeira líder do plantão.

Após a saída dos familiares, os profissionais voltam a examinar os pacientes e a realizar procedimentos, até às 17 ou 18 horas, quando os estagiários e residentes terminam seu turno. Às 19 horas, há nova troca da equipe de enfermagem e passagem de plantão. O número de pessoas trabalhando então é reduzido e, a partir das 22 horas, há rodízio da enfermagem. Os médicos, estagiários de medicina e fisioterapeutas permanecem de plantão até o início da manhã, sendo solicitados pela enfermagem quando necessário. Antes da chegada da nova equipe e do início de um novo dia há novo ciclo de exame dos doentes.

\section{armas Tegnológicas}

Essa unidade hospitalar possui uma organização voltada para o atendimento da rotina e para o enfrentamento de situações especiais, que surgem quase cotidianamente. Um desses episódios, por mim presenciado, ocorreu quando houve uma queda na pressão do oxigênio canalizado para os respiradores. Nessa ocasião, todos os sete pacientes internados respiravam por aparelhos. Eu estava no 'salão', olhando pela janela de vidro o doente internado no isolamento, um menino de 12 anos que não estava bem, cuidado por vários profissionais. De repente começou a tocar uma sirene - que soou como o aviso de bombardeio em filme de guerra - no quarto de isolamento e, logo em seguida, alarmes dispararam nos outros leitos. Os médicos plantonista e residente se encaminharam para os leitos, dando ordens, organizando o trabalho. A enfermeira chefe telefonou para o setor de manutenção, reclamando, informando a situação e solicitando reparo urgente. Todos os pacientes passaram a ser ventilados manualmente por dois profissionais. 
As sirenes não paravam de tocar e o médico plantonista movimentava-se de um leito para outro, conferindo as condições de cada paciente e o trabalho da equipe. $\mathrm{O}$ menino internado no isolamento estava ficando arroxeado. De repente todos os alarmes silenciaram, só permanecendo os apitos costumeiros dos aparelhos. Tudo retornou à normalidade. Uma situação atordoante, impossível de ter seu tempo de duração determinado. Um momento especial, para o qual as equipes estão treinadas e acostumadas, o que ficou evidente, pelo episódio não ter sido objeto de comentários dos profissionais.

Esse exemplo evidencia a importância da aparelhagem, pois para que um CTI funcione bem são necessárias, além da especialização e multiprofissionalidade da equipe, energia elétrica e tecnologia, sem o que os pacientes não permaneceriam vivos. O hospital possui um gerador exclusivo para os setores altamente dependentes de energia elétrica: Centro Cirúrgico, Unidade Coronariana, CTI cardíaco, sala de Diálise, CTI Neo-Natal e o CTI Geral. Toda a aparelhagem desse setor conta com no-breaks para eventual queda ou falta de energia. Durante a observação, o CTI recebeu o aviso de que haveria falta de energia em um determinado dia, em razão da troca de um transformador. Os eletricistas avisaram que a interrupção duraria, provavelmente, 15 minutos. Diversos profissionais comentaram sua preocupação, que parece ser a de todos aqueles que trabalham em CTI:

Durante um plantão num outro hospital faltou luz durante quatro horas e ai foi um grande problema; os pacientes ficaram sem respiradores $e$ os médicos e enfermeiros tiveram que ficar ventilando os pacientes manualmente no ambu. Mas não deu pra segurar todos os pacientes e alguns foram embora... Esse é um grande problema, pois todos os aparelhos são dependentes da eletricidade. Não há pior terror para um médico de CTI do que faltar luz. (médica-residente)

A aparelhagem desempenha importante papel no controle e vigilância dos pacientes internados, de modo que, sem esses recursos, o trabalho do profissional seria quase impossível.

\section{"Você Estuda Melhor o Paciente Aquu"}

O ensino e o aprendizado são atividades presentes na prática do CTI pesquisado, diferenciando-o de outros hospitais. Aprender medicina não é simplesmente a incorporação de novas informações ou apreensão de novas perspectivas. 
Segundo Byron Good, é habitar um novo mundo de forma vivenciada. O universo da medicina é preenchido por objetos que não fazem parte do cotidiano e seu aprendizado significa a entrada em um sistema específico de realidade (Good, 1997).

Como o CTI observado está inserido em um hospital universitário, várias tarefas são executadas pelos estagiários, supervisionados pelos profissionais staff. Para estes, esta é mais uma atividade:

Estando no hospital universitário, é inerente a todas as categorias a questão do ensino. A relação ensino-aprendizado; quer dizer, tanto você passa a tua experiência como você vai para um curso de reciclagem, você tem que ficar nesse círculo ensino-aprendizagem, por estar numa instituição universitária. (enfermeira)

Aqui dentro, como é um hospital universitário, você acaba tendo outras funções. Você acaba muitas vezes fazendo o papel de professor, porque tem que orientar interno, estagiário e residente. E você não ganha nada por isso, não. Você dá cursos e dá aula. É uma atividade inerente também aqui. Quer dizer, além da atividade com o doente, você ainda tem uma atividade paralela, a atividade didática. (médica)

Freqüentam a unidade estudantes de medicina e fisioterapia, além de profissionais recém-formados como os residentes de medicina, fisioterapia e enfermagem. Há também estagiários já formados em psicologia (à ocasião, apenas uma), cursando especialização no serviço de Psicologia Médica. A única categoria profissional que não conta com estagiários é a de auxiliar de enfermagem.

Os profissionais do CTI valorizam a atividade docente: eles orientam os 'alunos' de forma atenta e aparentando satisfação. Certo dia o médico plantonista respondeu a várias perguntas de estagiários, explicando pacientemente como preencher prescrições de medicamentos e pedidos de exames. Em alguns momentos ele brincava com os 'meninos', como chamava os estagiários, e comentamos que ele agia como uma 'babá'. O médico riu e disse que os 'meninos' davam trabalho, mas que isso fazia parte do trabalho, pois gostava muito de ensinar, pretendendo inclusive fazer um mestrado. Muitas vezes o médico staff propôs que os estagiários estudassem algum assunto, combinando discussões teóricas para os horários mais tranqüilos do plantão.

Os estudantes de medicina iniciam o estágio no setor após prestarem concurso, com prova teórica. O estágio é de um ano e os melhores estagiários podem prorrogar a estada por mais outro ano, com autorização da chefia do CTI. Como disse um estagiário, ao comentar o início de sua prática no CTI: 
Tem um concurso. A gente fez a prova, foi em dezembro se não me engano. Foram 16 vagas para um plantão de 24 horas por semana, e tinha uns cem candidatos. É, uns cem candidatos, mesmo não sendo remunerado. (estagiário de medicina)

A unidade, por ser considerada de excelência, é concorrida e bem cotada pelos estudantes, proporcionando uma boa oportunidade de aprendizado. A fala do mesmo estagiário é ilustrativa: "Você estuda melhor o paciente aqui e tem uma abordagem melhor do paciente. Enfim, você tem uma medicina de mais alto padrão que eu posso exercer. Isso está somando na minha formação" (estagiário de medicina).

Apesar de muitos estudantes não pretenderem se especializar em medicina intensiva, consideram necessário, para uma boa formação médica, o aprendizado sobre casos graves e o treinamento prático em um setor com recursos tecnológicos. É na prática que o estudante é efetivamente 'forjado', adquirindo segurança para se iniciar na profissão que escolheu. Segundo Sérgio Rego, há uma especial predileção dos alunos pelos serviços de emergência, maternidades e unidades de terapia intensiva como campos de prática (Rego, 1995).

A hierarquia de valor das especialidades apresentada pelos estagiários reproduz a hierarquia de prestígio dos setores hospitalares. Há um aspecto técnico relevante na valorização desse estágio: a oportunidade de aprendizado e treinamento em procedimentos considerados 'invasivos' e arriscados, como entubação, dissecção venosa e punção. Outro fator a contribuir para o interesse no CTI é que a faculdade não proporciona um ensino referente a certos aspectos práticos, como o preenchimento de prontuários e requisição de exames: "Isso a faculdade não dá pra gente, você vem com a carga teórica, não tem a carga prática. Preencher, fazer uma prescrição na faculdade eles não explicam" (estagiário de medicina).

Durante a 'visita' o processo de aprendizagem é sempre presente, uma vez que a história e o estado dos doentes são normalmente relatados por um estagiário de medicina ou por um médico-residente. Os médicos staff ouvem os relatos, fazendo correções em sua forma, questionando sobre as possíveis causas dos dados patológicos ou as relações entre sintomas e dados laboratoriais. Muitas vezes perguntam aos 'alunos' o que eles sugerem para a programação terapêutica. Freqüentemente há 'aulas' dos médicos mais experientes aos estudantes com sugestões de leituras teóricas sobre determinados assuntos. Uma 'aula' desse tipo pode ser exemplificada em uma das 'visitas' observadas, na qual a médica da rotina resumiu a situação de uma paciente: 
Ela teve uma boa evolução, com possibilidade de alta do CTI. Mas ela fez broncoespasmo e atelectasia à direita, e retornou à prótese respiratória. Por que voltou à prótese? Por que fez taquipnéia? O que aconteceu com a doente agora? O problema inicial a gente sabe e resolveu, mas e agora? (médica responsável pela rotina)

A seguir, dirigindo-se para o estagiário responsável pelo leito:

Não adianta você falar dos parâmetros de hoje, tem que contar toda a história, toda a evolução para que a gente possa avaliar e saber do quadro. Foi algo respiratório, não parece ter sido infecção, e aí? Ela não tinha broncoespasmo, passou a ter por quê? A maior chance é de estar embolizando. E como confirmar essa hipótese? (médica responsável pela rotina)

O estagiário se manifesta: "Não sei... acho que...", ao que a médica retruca:

Achismo não dá em medicina, temos que trabalhar com verificações. Mas tem que se correr atrás dos exames, ir lá e conversar com o pessoal. A cintigrafia pulmonar eles fazem aqui nos hospital, mas primeiro fazem de perfusão. (médica responsável pela rotina)

A médica passou então a discorrer sobre os tipos de embolia, o que é cintigrafia e o que esse exame pode indicar. Descreveu todas as possibilidades diagnósticas, os métodos possíveis para diferenciações diagnósticas, a seqüência mais lógica dos exames e as possibilidades terapêuticas. Concluiu sua explanação com a orientação prática a ser seguida a partir daquele momento. Todos os profissionais presentes assistiram à aula com atenção e interesse, muitas vezes fazendo perguntas e apresentando sugestões.

Esse exemplo ilustra o processo de aprendizagem de um estudante de medicina. Ele aprende a ver e a decodificar o corpo humano à luz de múltiplos saberes. O corpo é construído sob nova perspectiva, passando a constituir um conjunto organizado de percepções e respostas que emergem desse corpo como lugar de conhecimento médico (Good, 1997). O estudante de medicina deve conceber as pessoas doentes como pacientes e aprender a se comunicar - escrita e oralmente - tanto com os diversos profissionais da saúde quanto com os pacientes e seus familiares. Nesse sentido, Good considera as histórias médicas como meios de organização e de interpretação da experiência, ao formular a realidade e com ela interagir. A apresentação de casos não é meramente uma forma de descrição da realidade, mas um modo de construí-la (Good, 1997). 
Ao longo do tempo, os alunos aprendem a 'visualizar' e a apresentar os 'casos' na seqüência e forma propostas pelos 'orientadores'. Um estagiário salientou: "Outra coisa que notei: eu mesmo, no começo não sabia nem o que era importante no paciente. Agora, na 'visita', os próprios médicos perguntam: 'E isso?' 'E aquilo?' E você vai começando a ver o que é realmente importante (estagiário de medicina).

Os recursos visuais são muito utilizados na aprendizagem médica, na qual os estudantes aprendem uma forma alternativa de 'visão'. Paulo Gabriel Hilu Pinto (1997) compreende que a utilização de imagens como 'coisas' deriva da própria dinâmica do saber médico, que deposita em uma empiria radical sua garantia de cientificidade. Tal uso dos recursos visuais apresenta um grande impacto no processo de socialização dos estudantes de medicina. Em conseqüência, há o estabelecimento de um sistema de pensamento que representa o saber médico como decorrente da observação treinada da realidade, dificultando qualquer tentativa de controle consciente de seus pressupostos, que permanecem implícitos para os agentes do campo médico. Para Ludwig Fleck, o observar, no contexto do conhecimento, se dá de duas formas: inicialmente há o confuso ver e, após uma práxis, adquire-se o 'ver formativo'. Desse modo somente os iniciados em um campo delimitado têm capacidade para o observar científico, construído às custas da perda da visão do heterogêneo e da capacidade de visão do que contradiga esse 'ver formativo' (Fleck, 1986).

Os alunos aprendem a representar a doença e o funcionamento fisiológico mediante números e valores de laboratório, e conseqüentemente passam a proceder de acordo com tal representação. Esse processo é expresso claramente por um estagiário de medicina:

Estou aprendendo a levar uma medicina de uma forma mais organizada. Porque aqui no CTI o que acho importante é que tudo o que você faz você tem que escrever. Se eu levar isso pra minha vida médica vai ser muito legal. Porque tem muito médico aí que examina o paciente e não escreve nada, não fica relatado. Então estou aprendendo a ficar organizado, a organizar minhas idéias de uma forma adequada, clara, de uma forma que outras pessoas possam entender, que não seja só importante pra mim. (estagiário de medicina)

Good nomeia "práticas formativas" todos esses processos vividos pelos estudantes de medicina, que, para ele, não são simplesmente representações, mas formas poderosas de ação. Elas conduzem a intervenções e procedimentos: a educação médica autoriza determinadas práticas clínicas. O aprendiz pode - e 
deve - praticar, construindo o tornar-se profissional, aprendendo a raciocinar e a desenvolver seu trabalho em unidade multiprofissional. O mesmo estagiário de medicina salienta:

Fazer exames e se relacionar, ter contato com outras disciplinas. A gente estuda só medicina. Estou acostumado a conviver só com medicina. Aqui tenho que conviver com enfermagem, fisioterapia, com auxiliar de enfermagem, com médico de outras áreas, então em relação a isso também está ajudando, porque você tem que ter essa relação interpessoal, interdisciplinar. Porque acho que é importante na formação da gente. Porque não adianta também você ser só um bom profissional, tecnicamente falando, se não tem uma boa relação, isso vai acabar prejudicando seus pacientes. (estagiário de medicina)

Esse processo de aprendizagem também pode ser compreendido com as idéias e conceitos formulados por Fleck (1986). A ciência é concebida como um processo essencialmente coletivo, produto de um 'coletivo de pensamento' (unidade social da comunidade de cientistas de um determinado campo). O saber nunca é possível em si mesmo, mas somente sob a condição de existência de determinadas presunções sobre o objeto, subjacentes a qualquer vínculo de construção teórica. Portanto, não existe um observar livre de pressuposições, necessariamente estão implicados hábitos e decisões (Fleck, 1986). Pode-se observar a convergência do conceito de 'práticas formativas' de Good com o ver formativo de Fleck.

No processo de aquisição de um papel profissional, os alunos aprendem não somente conhecimentos teóricos e práticos, mas um estilo de vida, incorporando novos valores e posturas. Esse aspecto evidenciou-se nas repreensões feitas por médicos staff a estagiários, relativamente à postura corporal durante a 'visita' (por vezes sentando-se de costas para outros profissionais ou colocando os pés em cadeiras, ou ainda quando recostados nas cadeiras, não sentados corretamente) e na forma do 'aprendiz' se dirigir a outros profissionais.

É interessante apontar que muitos profissionais staff que trabalham há mais tempo nesse CTI iniciaram sua prática ali mesmo, como estagiários, passando a residentes e, após concurso, sendo efetivados:

Comecei a fazer estágio em CTI, queria aprender a coisa de doente grave, e gostei mais em termos de estrutura. Você atende melhor o doente. Eu acho que você vai vendo melhor as coisas. E gostei da dinâmica, do trabalho e fui ficando. (médica staff) 
Há uma valorização por parte dos profissionais do treinamento prático em sua formação. O estudante, ao iniciar sua aprendizagem prática em um campo da medicina mais valorizado, muitas vezes identifica-se com a especialidade. Dessa forma o antigo 'aprendiz' pode se tornar 'mestre', produzindo um reforço do próprio papel profissional na transmissão de valores e atitudes médicas.

\section{Notas}

1 O Conselho Federal de Medicina estruturou uma Câmara Técnica para discussão e regulamentação da especialidade denominada medicina intensiva. Essa Câmara conta com profissionais pertencentes às Sociedades de Terapia Intensiva de vários estados do Brasil.

2 O CTI possui uma série de equipamentos, utilizados conforme a necessidade dos doentes. São oito respiradores, sendo sete microprocessadores e um ventilador volumétrico; sete monitores cardíacos e dois monitores de hemodinâmica. Há também trinta bombas infusoras para medicamentos, quatro oxímetros de pulso (para medição da saturação da hemoglobina), três oxicapinógrafos (oxímetros de pulso com medição do gás carbônico expirado), dois desfibriladores, um eletrocardiógrafo portátil, quatro ventiladores de transporte (Bird) e duas centrais de monitorização cardíaca, estas instaladas no interior do posto de enfermagem e conectadas aos monitores cardíacos de beira de leito.

3 Os quartos de repouso são separados segundo as categorias profissionais e dispõem de banheiro, armários e camas beliche.

4 A música escolhida é instrumental, variando de erudita a popular, como bossa nova.

5 Ao devolver uma versão preliminar do texto, a médica que exercia a chefia do serviço corrigiu-me nesse ponto. Fiquei surpresa por não ter percebido os outros sete relógios, talvez pela quantidade de estímulos presentes no 'salão' (onde estão localizados seis relógios). Pude então constatar que a maior parte está posicionada a uma altura superior ao campo de visão de uma pessoa de pé, mas no campo de visão de um paciente deitado. Tal localização foi escolhida pelos integrantes do CTI na tentativa de permitir uma referência temporal aos doentes internados.

6 Há uma médica chefe da unidade, uma médica responsável pela rotina, cerca de dez médicos plantonistas staff. Há também médicos trabalhando em regime de contrato temporário; cerca de seis médicos residentes R1 e um R3. A letra R indica que se trata de profissional residente recém-formado, e o número indica o ano de residência. São cerca de 15 estagiários de medicina. Há uma enfermeira chefe da unidade e oito 
enfermeiros líderes de equipe, todos staff. Há também cerca de 35 auxiliares de enfermagem, a maior parte staff e alguns com contrato temporário. O serviço conta com duas secretárias. A nutricionista e a assistente social prestam assistência ao CTI, mas não são exclusivas do setor, trabalhando também em outros serviços do hospital. As distintas categorias profissionais não utilizam uniformes diferentes e, exatamente por isso, no início das observações, não era possível distinguir quem era médico, fisioterapeuta, enfermeiro ou auxiliar de enfermagem.

7 Por vezes constatei que, apesar da presença de diversos profissionais no ambiente, nenhum se dirigia ao leito onde um alarme disparava, o que pode ser explicado pelo acúmulo de ruídos, conduzindo a uma indiferença.

8 O termo 'visita' refere-se à visita do médico ao leito do doente para exame clínico. $\mathrm{Na}$ reunião de equipe (também denominada 'visita') são relatados o exame e a visita ao leito. 


\section{3 \\ Intensivista como Identidade Profissional}

\section{Relações Entre as Equipes}

O trabalho em CTI pressupõe a existência de uma equipe multiprofissional, pois sem os cuidados especializados das diversas categorias profissionais não seria possível o seu desenvolvimento. Cada profissional tem uma tarefa específica, fundamental para o funcionamento do setor. Durante o período inicial de observação, os intensivistas ${ }^{1}$ mencionaram uma série de vantagens em ali trabalhar, dentre as quais o bom relacionamento existente entre as categorias profissionais. No entanto, como em qualquer ambiente profissional, conflitos também ocorrem.

A enfermagem é terrivel, há muitos problemas. É muito difícil trabalhar com esta gente. Há um outro problema também: os estagiários estão começando, ainda estão inseguros, mas daqui a uns três meses vão estar se sentindo mais seguros e aí vão começar a mandar e tratar a enfermagem de uma maneira botando banca. E os enfermeiros estão ali há quatro, cinco anos, vão acabar se irritando com esses meninos. Isto tensiona a relação entre as equipes. (médico plantonista)

Os confrontos de poder ocorrem no setor, tanto entre as diferentes categorias profissionais como dentro de cada uma delas. O clima varia da hostilidade surda à belicosidade, chegando a discussões em voz muito alta. Vários códigos de hierarquia perpassam as relações entre as diversas categorias profissionais: em cada profissão há diferenças entre os staff, com mais tempo de prática e estabilidade funcional, e os menos experientes, sob contrato temporário. Entre as categorias profissionais também há posições diferentes, com os médicos ocupando uma posição superior. Apesar da hierarquia explícita, por vezes ocorre uma inversão: um estagiário de medicina 'botar banca' sobre enfermeiros staff, assumindo o papel de um médico staff, ignorando o código relativo ao tempo de serviço, um dos critérios de grande importância na hierarquização dos profissionais. A tensão 
entre médicos e enfermeiros é freqüente em ambiente hospitalar. Em uma das observações duas médicas staff examinavam um paciente, quando perceberam seus pés amarrados às grades do leito. As duas ficaram indignadas. Chamaram a enfermeira chefe e uma delas disse: "O que é isso? Virou rotina da enfermagem agora amarrar o paciente no leito?". A enfermeira argumentou com a recomendação do cirurgião para que o doente não movimentasse a articulação coxo-femural e que este havia tentado sentar-se na cama. A médica retrucou que a equipe de enfermagem deveria ter solicitado ao médico plantonista a prescrição de sedação medicamentosa. $\mathrm{O}$ ambiente ficou tenso e a enfermeira não mais dirigiu a palavra às médicas durante o plantão. Em outras situações, a hostilidade pode ser expressa por gozações e risos, como, por exemplo, quando um residente fez caretas para os colegas residentes pelas costas de um médico staff.

Por vezes há competição entre as categorias profissionais, com cada uma buscando afirmar sua competência sobre a outra. Certa vez uma estagiária de fisioterapia conversava, rindo muito, com uma colega:

Sabe o Fulano?!, Estagiário de medicina!!?, Ele achava que sabia de tudo, e não conseguiu pegar [uma veia ou artéria]. Ele metia banca e eu é que acabei fazendo, consegui de primeira. Tá vendo, eles, os estudantes de medicina, acham que são os tais e eu desbanquei ele. (estagiária de fisioterapia)

Quando indagados sobre as tensões e confrontos de poder nas relações entre as equipes, os informantes afirmaram que os confrontos, talvez como uma forma de minimizá-los, podem ser causados pela falta de comunicação entre os diversos profissionais. Todos os intensivistas entrevistados localizaram a dificuldade de relacionamento especialmente na equipe médica, tanto em seu interior como com as demais categorias, talvez um indicativo da relação de subordinação das diversas categorias à categoria médica. De acordo com depoimento de um médico plantonista:

Tem tensão até porque as pessoas esquecem que quem está com o doente, no sentido da responsabilidade, é o médico. Tudo o que acontecer é responsabilidade do médico, sem dúvida. Então você está tenso porque a responsabilidade é tua. (médico plantonista)

A prática do CTI pressupõe a existência de uma equipe multiprofissional. No entanto, há um responsável no que se refere à vida do doente: o médico. É, portanto, sua posição que está mais diretamente em jogo. Segundo Freidson (1988), 
o que diferencia a profissão médica das paramédicas é o grau de autonomia, prestígio, autoridade e responsabilidade que a profissão médica detém. Há, assim, uma divisão do trabalho organizada com uma hierarquia de autoridade, estabelecida e legitimada, não permanentemente explicitada, uma vez que é necessário um trabalho coordenado entre as equipes, que pode ser sabotado se a hierarquia ficar por demais patente.

De acordo com uma enfermeira, o CTI "é uma panela de pressão, tem épocas que está a ponto de explodir". A mesma expressão foi citada por profissionais de outras categorias, embora todos assegurassem que isso não ocorria mais.

Durante a observação, o clima variava muito conforme a equipe do dia. As equipes funcionam por sistemas de turnos diferentes: a enfermagem trabalha em plantões de 12 por 60 horas e as equipes médicas e de fisioterapia em plantões de 24 horas semanais. São, portanto, seis equipes de enfermagem e sete equipes médicas e de fisioterapia que se encontram uma vez a cada três semanas. A maior parte dos profissionais admitiu ter mais simpatia por algum colega, em particular. Quando os plantões coincidem, o clima é mais ameno, as brincadeiras são afetuosas e o ambiente é de cordialidade. Assim como há grupos com maior compatibilidade, há também os de claro confronto. Após algum tempo de observação, ficou evidente que o médico de tal dia não gostava da enfermeira de tal equipe e, quando eles trabalhavam no mesmo plantão, as fofocas, 'alfinetadas' e caretas eram previsíveis.

Há uma nítida tendência de cada categoria ter um melhor relacionamento com seus pares. As trocas entre os diversos grupos são menos freqüentes. A esse respeito há uma situação singular: um profissional que é o único de sua categoria na maior parte do tempo: a psicóloga. ${ }^{2}$ De acordo com vários informantes, seu trabalho é o mais complexo. Para um auxiliar de enfermagem, "a psicóloga faz o atendimento geral" e no dizer de um médico plantonista, "a psicóloga segura a cabeça de todos nós e dos familiares dos internados". Talvez seja o profissional que lide com a área mais abrangente do CTI: ocupa-se tanto dos doentes internados e de seus familiares, como das equipes e do relacionamento entre todos. Os médicos, fisioterapeutas e enfermeiros desempenham tarefas práticas, contando muitas vezes com a mediação de instrumentos, ao contrário da psicóloga, que lida diretamente com as emoções de todos os envolvidos no CTI. Ela trabalha com os sentimentos dos indivíduos, sejam estes os doentes ou os profissionais. Tal característica a diferencia dos outros grupos profissionais, pois para que ela possa trabalhar com as emoções da equipe torna-se necessária certa distância de seus colegas. De certo modo, a psicóloga funciona como uma observadora: seu trabalho demanda 
um movimento sucessivo de aproximação e distanciamento do objeto de intervenção. Dessa forma, a psicóloga ocupa um lugar delicado no CTI: ao mesmo tempo que pertence à equipe intensivista, também é observadora e intervém sobre a equipe.

Mesmo com todas essas diferenças e tensões entre os diversos grupos que constituem o CTI, há uma identidade profissional singular, claramente delineada, que perpassa todos os agentes de saúde envolvidos com o CTI.

\section{No Topo do Hospital}

Quando indagados sobre as qualidades do exercício profissional em CTI, os informantes apontaram: a medicina do mais alto padrão associada à tecnologia de ponta; a maior organização da rotina do que em outros setores hospitalares e o trabalho multidisciplinar, acarretando maior segurança nas tarefas desenvolvidas. O trabalho da equipe intensivista é valorizado pelos seus integrantes por ter tais características.

A maior parte dos profissionais expressou satisfação em trabalhar em CTI, particularmente nesse hospital, por ser um serviço considerado de qualidade. Ao começo da observação, esse CTI havia ganho um prêmio por ser, na avaliação de uma comissão técnica externa à instituição, o serviço de melhor qualidade do hospital. Muitos profissionais que disseram trabalhar em outros CTIs (inclusive privados), se orgulhavam de trabalhar nessa unidade, apesar de a remuneração ser menos vantajosa. $\mathrm{O}$ orgulho advinha tanto do fato de se tratar de um serviço considerado excelente em relação à instituição, como em comparação a outros hospitais. Esse aspecto fica claro nas falas dos profissionais, que definem o setor como: "o topo do hospital" (médica-residente); "o supra-sumo" (enfermeira); "o coração do hospital" (fisioterapeuta-residente); "está à frente das outras unidades" (enfermeira); "um ponto vital dentro de um hospital" (médica staff).

Todas essas imagens apontam para a idéia de o CTI ser essencial ao hospital e, mais além, para o fato de ser uma unidade que ocupa posição hierárquica superior aos outros serviços da instituição. A fala é ilustrativa dessa imagem construída pelo profissional do CTI:

O nosso CTI aqui é bom, sabe, é como um jumbo, e a enfermaria é um teco-teco. Aqui nós temos enfermeiras de primeira, aparelhagem mais moderna, estudantes que prestaram concurso para estagiar aqui. É 
tudo de qualidade aqui. (médico plantonista dirigindo-se a um familiar de doente internado)

A posição hierarquicamente superior que o serviço ocupa se justifica tanto pelos equipamentos (aparelhagem mais moderna), quanto pelo nível de profissionalização de suas equipes. Segundo os profissionais da área, tal capacitação é crucial em um momento em que a vida é ameaçada de modo radical, o que ocorre tanto em pacientes de CTI como nos de Pronto-Socorro. Entretanto, em serviços de Emergência, há escassez de aparelhagem e de materiais, como disse uma médica: "pronto-socorro é muita confusão, falta muita coisa de material" (médica).

Se, por um lado, a especialização nesse campo é valorizada, por outro, apresenta uma série de limitações. Trata-se de uma atividade desempenhada necessariamente por uma equipe em ambiente institucional, o que automaticamente exclui o exercício autônomo em consultório privado. É também exercida em regime de plantões, o que, para a maior parte dos intensivistas, é muito cansativo e desgastante. Como disse, em entrevista, um médico plantonista:

É uma especialidade em que se fica muito dependente de hospital. Não se pode ter uma atividade autônoma, um consultório, o que depois de certo tempo é exaustivo. Um pneumo ou um gastro podem ganhar dinheiro fazendo broncoscopia e endoscopia, podem atender em consultório. (médico)

O cansaço causado pelo regime de plantões é percebido como um dos principais fatores de desgaste no trabalho em CTI. De fato, o ritmo de trabalho é intenso e muitas vezes os profissionais almoçaram em torno das 16 horas, quando sua jornada tinha se iniciado às 7 ou 8 horas da manhã. Ao comentar esse fato com um médico-residente, ele disse: “... parece que aqui no CTI não há tempo para refeições, estas parecem coisas frugais diante de tanta coisa que se tem pra fazer".

Além dessas características, contribui também o fato de o profissional lidar com situações de extrema gravidade e instabilidade, que o pressiona a tomar decisões com rapidez. Um médico que trabalha nesse CTI há mais de 15 anos declarou:

Tem o desgaste físico e emocional. Físico pelo cansaço da atividade continuada, 12, às vezes 24 horas. E o emocional, principalmente por isso, você está aqui tranqüilo, e de repente você tem que ter uma atividade máxima, raciocínio a toda. Isso cansa muito, desgasta muito. (médico plantonista) 
A decisão instantânea pode ser causadora de tensão, mas também é o que motiva o especialista. Como disse um outro médico: "O mais interessante é essa briga junto com o doente grave pela vida. Vamos chamar assim: da vida com a morte" (médico plantonista). O desgaste vivido pelo intensivista na batalha contra a morte pode ser recompensado quando uma vida é salva. O exercício profissional do intensivista é muitas vezes descrito pela equipe como uma atividade heróica. Quando perguntados sobre o que é gratificante no trabalho em CTI, as respostas se repetem:

Ah, é tão gratificante você saber que se matou de trabalhar, que você envolveu um monte de gente, discutiu várias coisas, até se estressou, mas que o produto foi aquele, a alta do paciente, isso te dá estímulo. Vale a pena continuar batalhando. (enfermeira)

É muito gratificante porque você pega com uma certa freqüência pessoas que, se não tivessem um tipo de atendimento que a gente oferece, elas não sobreviveriam. Em outro ambiente não teriam chance de sobreviver. (médico plantonista)

Esses aspectos da atividade do profissional intensivista são apontados na pesquisa desenvolvida por Ana Pitta (1991) sobre o processo de adoecimento e a natureza do sofrimento de profissionais de hospitais. Na literatura científica, cresce o número de comunicações referentes a agravos psíquicos, medicalização, suicídios de médicos, enfermeiros e porteiros de hospitais. A autora postula a tese de que a insalubridade ou o caráter penoso do ofício, em razão da permanente exposição a um ou mais fatores que produzam doenças ou sofrimento no trabalho hospitalar, decorre da própria natureza desse trabalho. Para Pitta, as determinantes principais do sofrimento do profissional estariam contidas no próprio objeto de trabalho - a dor, o sofrimento e a morte do outro -, além das formas de organização desse trabalho essencial e diuturno. O mesmo objeto de trabalho é referido nesse estudo como capaz de produzir satisfação e prazer quando as condições permitem aos trabalhadores que suas tarefas sejam socialmente valorizadas (Pitta, 1991).

O trabalho do profissional de saúde envolve, ainda segundo Pitta, não somente o lidar com questões técnicas e científicas, como também com outros aspectos de natureza filosófica, moral, política, econômica e social. Quando perguntados sobre as qualidades que um profissional de CTI deve ter, vários intensivistas entrevistados responderam que, além do conhecimento técnico e atualização constante, requisitos como 'humanidade, solidariedade e capacidade de relacionamento inter-pessoal' são extremamente importantes. No entanto, tais aspectos vinculados à prática humanitária tendem a se situar em plano hierárquico 
inferior à competência técnica: "Os profissionais de CTI se preocupam muito em ter uma boa formação técnica. Mas eu acho que muitas vezes isso toma a frente do lado humano, e esse lado humano fica esquecido" (psicóloga).

O intensivista percebe com clareza a complexidade do seu campo de atuação, o que considera um componente de seu desgaste físico e emocional. Para vários profissionais, o tempo de trabalho em CTI deveria ser limitado, a exemplo de outros países - onde há legislação estabelecendo o tempo de exercício profissional entre dez e vinte anos contínuos. Para outros, a proposta é mais radical, como para uma médica: "O médico devia ter uma prática igual a um sacerdócio. Seria assim: você não ter família, você ficar lá, fazendo só aquilo" (médica).

Uma idéia se apresenta conjugada ao 'sacerdócio': a imagem de total abnegação, do intensivista como 'salvador'. Dessa forma, o intensivista constrói tanto uma auto-imagem de heroísmo como de excentricidade. No dizer - demonstrando orgulho - de um médico: "É bom você ficar logo sabendo que todo mundo que trabalha em CTI geralmente é meio doido" (médico plantonista); o que é corroborado por outra fala: "Eu acho que a maioria dos médicos que trabalha em CTI ... falta um parafusinho" (médica-residente).

A partir da escolha da carreira em CTI, o profissional constrói uma identidade específica, onde a legitimação da especialidade ocupa posição privilegiada.

\section{TorNaND0-SE INTENSIVISTA}

Uma reunião do Fórum da Câmara Técnica do Conselho Regional de Medicina do Estado do Rio de Janeiro, destinada a discutir a proposta de regulamentação da especialidade em terapia intensiva e dos CTIs no Brasil, realizou-se pouco antes do início da observação. Buscando uma aproximação ao campo da pesquisa, fui assisti-la. O médico intensivista obtém a titulação em curso de especialização ou em prova teórica de sociedade oficial de Terapia Intensiva. Além disso, deve também ter um tempo de experiência prática em CTI, adquirido em estágios ou em residência. Segundo representantes da Sociedade de Terapia Intensiva do Rio de Janeiro, a nova especialidade deveria englobar as seguintes especialidades: clínica médica, cardiologia, pneumologia, cirurgia, anestesiologia, podendo alcançar até a engenharia biomédica. No Fórum citou-se uma estatística, indicando uma mortalidade menor no CTI e em hospitais, para os pacientes tratados por médicos intensivistas. As características esperadas de um intensivista seriam: 
Os conhecimentos clínicos de um médico clínico, a destreza manual de um cirurgião, a capacidade de tomar decisões com a rapidez de um emergencista, atualização técnica avançada, liderança de equipe multidisciplinar, noções de fármacos como um farmacêutico, humanismo e educação continuada. (médica representante da Sociedade de Terapia Intensiva do Rio de Janeiro)

Com tal abrangência e tamanha qualificação, o superlativo 'super' pode ser utilizado para designar esse profissional, que muitas vezes se reconhece e é reconhecido como um 'superespecialista', acima de seus pares profissionais.

No primeiro dia de observação ocorreu uma situação que corroborou essa identidade profissional superlativa veiculada no Fórum. Estava sendo dada alta do CTI a uma paciente ali internada por encaminhamento da equipe médica de uma enfermaria. A equipe do CTI constatou tratar-se de um caso psiquiátrico, erroneamente diagnosticado como patologia neurológica. Vários comentários foram feitos pelos profissionais, sempre acompanhados de risos referentes à 'ignorância' da equipe da enfermaria. Repetidamente os intensivistas referiam-se aos profissionais de outras especialidades como 'ignorantes'. A fala de um médico plantonista, durante um dos períodos de observação, é ilustrativa: "Os outros médicos não sabem muita coisa, por exemplo, não sabem a diferença de sedação e analgesia".

A auto-imagem do profissional intensivista é de superioridade em relação a seus pares, ao pressupor ter uma bagagem de conhecimentos maior e melhor. Uma médica staff entrevistada expressou com muita clareza esse aspecto, posicionandose criticamente em relação à reivindicação de superioridade do intensivista: "um acha sempre que faz melhor, que o seu serviço é melhor. O intensivista, acho que sempre teve muito isso de considerar que os outros não sabem nada, que estão fazendo errado".

De acordo com Freidson (1988), é possível conceituar profissão como uma ocupação cujas obrigações desenvolvem e utilizam, de forma sistemática, o conhecimento geral acumulado, visando a solução de problemas postulados por um cliente, tanto individual como coletivo. Portanto, no hospital a autoridade profissional centra-se naquele que detém o conhecimento especializado para o problema específico do doente. O nível de profissionalização é regido tanto pelo grau de êxito na reivindicação por competência técnica exclusiva, como pelo ideal de trabalho e às normas de apoio à conduta profissional. Com o progressivo aparecimento de serviços especializados, estabelecem-se novas relações entre os setores hospitalares, criando novas interdependências técnicas e funcionais, cuja lógica é determinada pela hierarquia de valores que coloca os serviços de ponta e as atividades que lhes são 
associadas como elementos primordiais das políticas médicas no hospital (Carapinheiro, 1998). Com distintas formações, os profissionais de CTI se unem em torno de um senso de identidade, reivindicando competência específica e compartilhando valores comuns em um campo com clara delimitação e controle sobre a seleção dos treinados. O trabalho em CTI gera um sentimento de pertencimento que perpassa todas as categorias profissionais que nele atuam, validando a denominação genérica do profissional de CTI como intensivista. Esse aspecto é claramente ilustrado na fala de um médico plantonista:

O médico, a enfermagem, as auxiliares daqui, nossa! Porque eles acham que sabem mais do que todo mundo. Eles só não sabem mais do que o doutor de CTI, mas do que qualquer outro doutor eles sabem mais. Então, o doutor chega aqui, o residente, ó, pequenininho. O pessoal da enfermagem esnoba ele. Esnoba tudo até porque ele não tem experiência, e o pessoal da enfermagem tem, são ótimos aqui. Nossa, ele fica no chãozinho.

O lugar privilegiado do intensivista diante de seus pares na instituição é embasado em sua competência, ancorada em larga medida no conhecimento e na prática com a aparelhagem e tecnologia. A fala de um médico é ilustrativa: "O médico leigo entra aqui e diz: nossa, quanta máquina. E não é difícil de mexer, é facílimo". Nessas declarações, a expertise do intensivista é afirmada com a desvalorização do profissional médico - 'leigo' - de outra especialidade. É no contato com os outros setores hospitalares que o intensivista demarca mais claramente seu campo de saber e poder. Sua identidade profissional específica é assim construída por contraste aos demais setores da instituição, ao ponto das diferenças entre as diversas categorias profissionais, como entre médicos e enfermeiros, serem diluídas ante a construção dessa identidade comum - intensivista.

\section{Os 'Bambambĩs'}

Os contatos entre o CTI e outros setores do hospital não são homogêneos e o intensivista estabelece distinções entre eles. Alguns serviços são previamente desqualificados, como revela o diálogo ocorrido em uma 'visita', quando um estagiário perguntou ao médico staff: “o serviço X não poderia....?”. O profissional mais experiente interrompeu: "o serviço X não serve para nada". Enquanto alguns setores 'não servem para nada', outros são valorizados, especialmente quando o 
CTI solicita exames ou pareceres de outra unidade e é rapidamente atendido. Isto pode ser exemplificado por um episódio ocorrido em uma 'visita', quando avistou-se (através da janela de vidro da sala) a entrada de dois médicos com um grande aparelho. Os seguintes comentários foram então feitos: "É a equipe que veio fazer o ecocardiograma da paciente" (médica-residente). "É um equipamento moderno, altamente sofisticado" (médico plantonista). "Pois é, alto luxo, de vez em quando eles vêm até aqui colaborar conosco" (médico plantonista).

A equipe externa foi valorizada ao reconhecer a prioridade do CTI e colocar sua aparelhagem sofisticada à disposição de um setor considerado por seus membros como fundamental. De certa forma, o especialista que atende prontamente à solicitação do CTI reconhece sua preeminência em um sistema no qual a agilidade da resposta é referência fundamental na complexa relação entre saber e poder que ordena a profissão médica. O impacto da racionalização técnica nas práticas médicas pode ser avaliado pelo grau de especialização atingido em suas atividades, determinando a posição de cada serviço no contexto da hierarquia dos serviços institucionais.

Algumas especialidades são mais solicitadas, como a Nefrologia, por contar e dominar aparelhagem específica para diálise que o CTI não possui. Geralmente o contato é feito com muita rapidez e eficiência, o que é valorizado, como indicou em entrevista um médico plantonista:

Os serviços que a gente tem a maior facilidade de trânsito seriam a Nefrologia e a Cirurgia de Tórax. São os dois que a gente tem mais troca, porque eles estão muito presentes aqui. Quando a gente solicita, eles são extremamente atuantes e participam realmente.

Contudo, as relações não permanecem sempre da mesma forma, pois se o outro serviço não se conduz como esperado pelo intensivista, pode vir a ser rapidamente desqualificado. Uma médica staff, durante uma discussão na 'visita', referiu-se negativamente à mesma especialidade, tão elogiada por outro médico:

Pois é, e a Nefro veio questionando porque ele [o paciente] não voltou a urinar! Eles questionando a gente porque o cara ainda não fez xixi! Eles é que tinham que dar a resposta pra gente, qual é! É, neste hospital tem essas coisas, eles é que têm que saber o porquê. O cara não faz xixi, e cobram da gente.

Com base nessas considerações pode-se depreender que os confrontos com os outros serviços do hospital são freqüentes e inevitáveis. Parece que um setor está sempre à espreita, aguardando algum deslize do outro, de forma a afirmar sua 
superioridade. A competição é continuamente presente. A competência do profissional da saúde e o cuidado do doente são utilizados para demarcar um campo de poder institucional próprio. No dizer de uma enfermeira, em entrevista:

E aí, de repente, quando sai um paciente daqui com uma úlcera de pressão, parece que é um pouco como se eles, do outro setor dissessem assim: ah, deixa eu destruir essa coisa que é esse CTI-saber. Esse saber todo deles não impediu uma úlcera de pressão. Aí tem colega que fala: mas puxa, que paciente que vocês mandaram, olha o paciente aqui com essa úlcera de pressão.

A transferência de um paciente do CTI para a enfermaria provoca no intensivista uma preocupação em relação à qualidade de assistência que o doente passará a receber. Como disse em entrevista uma enfermeira: "vai lá para fora e é como se o mundo lá de fora não vai cuidar da mesma forma. O doente não vai ter os mesmos profissionais daqui. É como se fosse haver uma perda".

O intensivista percebe-se como um profissional que, em geral, sabe muito mais que seus colegas, sobretudo nos cuidados relativos a estados físicos de grande gravidade. Para cuidar desses quadros clínicos extremos, o intensivista utiliza uma série de equipamentos, com uma tecnologia que o diferencia de seus colegas. Além de contar com maior número de máquinas, a aparelhagem do CTI é mais moderna do que a de outras unidades hospitalares. Durante a observação, um médico plantonista disse, ao se dirigir a um familiar de internado: "O nosso aparelho é melhor do que o lá de baixo. Ele [o doente] estava antes num fusquinha e agora está numa Mercedes". A fala de uma residente, em entrevista, também é ilustrativa:

Porque na enfermaria é aquela coisa, não tem recurso. Aí o doente acaba morrendo na sua mão. Às vezes você poderia salvar um doente que realmente mereceria. ${ }^{3}$ É muito bom você ter todas essas máquinas, mas você tem que saber mexer muito bem.

A bagagem de conhecimentos técnicos especializados, associada à moderna e sofisticada aparelhagem produzem uma imagem do CTI que o coloca em posição superior aos demais serviços hospitalares. Em conseqüência de tal imagem, profissionais de outros setores já se apresentam submissos ao saber e ao poder do intensivista, quando deles necessitam. Em várias ocasiões, médicos de enfermarias solicitaram vaga para algum paciente, dando a impressão de estar 'pedindo um favor' ao colega intensivista. Essa visão confirma-se na fala de um plantonista: "Mas, olha, eu já vi cenas aqui de eu ficar com pena do colega que veio pedir vaga". 
A posição de superioridade que os intensivistas reivindicam para si transparece em um discurso reativo à imagem que, a seu ver, os outros profissionais da saúde da instituição formariam sobre eles. Quando indagado sobre as relações entre a equipe do CTI e os outros setores do hospital, um auxiliar de enfermagem declarou:

Porque o nosso setor é um setor fechado, nós não temos atendente nenhum lá fora. Apesar de todas as vezes em que saio, eu converso, falo o máximo, até pra derrubar esse mito mesmo. A gente tem o nome de elite lá fora por trabalhar em CTI. Digo sempre o seguinte: que a gente não é elite, que a gente rala muito, que a gente fica preso aqui o dia todo, que a gente só tira uma hora de almoço e volta pra cá, não podemos sair daqui. Mas o nosso relacionamento não é bom só por isso não, é a distância que separa um setor fechado, que o pessoal acha que não pode entrar, nem vem aqui, nem eles podem vir ver a gente, nem a gente pode descer também.

Falando sobre sua relação com as colegas de outros setores, disse uma enfermeira:

Mas pelo discurso delas é isso, a gente aqui é um outro hospital. Pelo que vi ontem, eu confirmei o que parece que todas as categorias confirmam: ah, é porque é o CTI. É como se nós fossemos os bambambãs, como se a gente tivesse tudo. Como a gente tem mais tecnologia, a gente dispõe de uma facilidade maior em termos de conhecimento.

O intensivista considera injusta a classificação de 'elite' e se queixa da visão de seus colegas. No entanto, expressa claramente o orgulho de exercer uma função essencial, que o impede de ausentar-se de suas tarefas, a exemplo de seus colegas de outros setores. Ao mesmo tempo que se sente colocado à distância por seus pares, o intensivista desqualifica o trabalho dos profissionais das enfermarias, que podem circular mais livremente pelo hospital, indicando uma visão de que o trabalho em enfermaria possui menor valor do que o de CTI. Uma hierarquia é construída institucionalmente na distribuição de serviços: o profissional que lida com os casos de maior gravidade tem prioridade no acesso aos recursos materiais e tecnológicos. Como disse, em entrevista, um médico plantonista:

A dependência não flui bem, mas pra nós [do CTI] é fácil. Se um doente da enfermaria for pedir uma endoscopia de urgência, a resposta é: ah, pode ser amanhã. O CTI quando pede, com esse problema da vida e da morte, se falar não, a gente vai lá e atropela. O doutor não sei quê [do $\mathrm{CTI}$ é o poderoso. Pare tudo que o meu doente vai chegar. E pára. E se 
você peitar o processo, eles vão perder. Tem um problema, demora, mas se você for lá e disser: olha, é agora, quero é agora. Então escreve aqui que não vai fazer agora. É CTI, tem prioridade. O nome já diz, Centro de Tratamento Intensivo, tem que ser agora.

Essa fala indica que ao lidar com indivíduos com grande risco de morte, qualquer situação que implique em retardos às solicitações do intensivista são passíveis de dar origem a um processo ético. O intensivista pode exigir que seu colega registre a recusa ao atendimento da solicitação. A superioridade hierárquica do intensivista é construída não somente por sua bagagem de conhecimentos teóricos e técnicos, mas também por sua capacidade de lidar com a morte. Como enfatizou o médico em sua fala, o intensivista pode pressionar o colega, face ao risco de vida de um paciente. Tal hierarquia dá margem a confrontos entre intensivistas e outros médicos do hospital. Certa vez a equipe médica estava reunida na 'visita' e um grupo de médicas chegou para realizar uma broncoscopia, solicitada para um dos pacientes do CTI. Depois de examinarem o paciente, as médicas chamaram o médico-residente responsável e comunicaram que não mais iriam fazer o exame. A freqüência cardíaca da paciente tinha diminuído, o que, segundo elas, colocaria a vida dela em risco. Após tentativas infrutíferas do residente em persuadir a equipe da broncoscopia a realizar o exame, ele solicitou ajuda à médica staff. Os dois médicos (a staff e o residente) saíram da sala de reuniões para discutir com a médica staff da equipe de broncoscopia. "Agora vai ser briga de cachorro grande", observou outra médica-residente, referindo-se ao confronto entre duas médicas staff, em posições hierárquicas semelhantes em termos institucionais. Após algum tempo, a intensivista staff retorna à sala de reuniões, dirigindo-se ao residente $\mathrm{R} 3$ que não conseguiu se contrapor à equipe da broncoscopia: "Pô, cara, você tem que se impor, senão não dá pra trabalhar assim. Elas estão fazendo o exame. Também não sabiam que a paciente está tomando uma medicação que causa bradicardia" (médica staff).

Essa situação aponta uma das principais fontes de onde emana o poder e o prestígio do intensivista: seu conhecimento. A intensivista staff mostrou a importância do esclarecimento da medicação utilizada. A médica da broncoscopia, desconhecendo o uso de medicamento que alterava o ritmo cardíaco, desaconselhava a realização do exame. A staff intensivista demonstrou na prática, para os iniciantes, como o saber competente constrói uma identidade diferenciada da de sua colega. A identidade do intensivista funda-se tanto em sua competência, que, segundo a staff, o residente não soube utilizar, quanto no poder de sua imposição. Quando a médica e o residente saíram para discutir a broncoscopia, outro 
médico-residente comentou: "não entendo qual é o medo da médica da bronco, pois se a paciente parar, já está aqui dentro mesmo".

Essa fala é reveladora de outro aspecto da origem do poder do intensivista. Conseguir 'reverter uma parada', expressão utilizada com freqüência pelos intensivistas, que significa 'devolver' a vida. Ao conhecimento e à técnica é conjugado um poder, que seu colega de outra especialidade não tem - e por isso o residente fala sobre o medo que, aparentemente, a equipe do CTI não sente. Cabe aqui a hipótese de que o medo do intensivista só pode ser expresso por meio do medo dos outros profissionais, externos ao CTI. Assim, o poder do intensivista emana de seu domínio sobre a morte. Os outros especialistas (como as profissionais do exemplo) temem é esse poder sobre a vida, de regulá-la, de discipliná-la. Uma das circunstâncias que tornam mais nítidas as características desse poder é o erro médico:

O médico é antipático, é o Deus, ele dá a vida e ele vê os erros. Não vou chamar de erros... incidentes. É aqui que a gente vê: se o cirurgião foi operar e lesou alguma coisa, ele vem pra cá. Então ele vem humildemente falar pra nós. E você vê e você sabe da história. Então se acontecer um acidente na enfermaria, o doente vem parar aqui. Então nós sabemos de tudo. Nós pegamos a pessoa, o médico na parte mais chata dele. Isso é com a gente. E o médico de CTI é o seguinte: é antipático, é um nojo, antipaticíssimo. Eu posso ver esses dois lados. Porque aqui sou intensivista, no outro hospital sou médico de outra especialidade. (médico plantonista entrevistado)

Esse trecho de depoimento revela um ponto muito sensível da prática médica: o erro do profissional, a falha que aponta o limite de sua sensação de tudo poder e tudo saber. Ao solicitar a intervenção competente do intensivista, o profissional confirma tanto a posição de saber quanto de poder desse 'superespecialista'. O intensivista acumula uma série de informações, desde o relato do 'incidente' apresentado pelo profissional até o conhecimento teórico e os recursos técnicos necessários no lidar com as suas conseqüências. Esse tipo de evento consolida um sistema hierarquizado de posições no campo das especialidades, com o intensivista ocupando um lugar de poder privilegiado. Seu poder refere-se à possível regulação e controle da morte e está indissociavelmente vinculado ao saber técnico e à experiência prática no manejo dos recursos tecnológicos. 


\section{Notas}

1 O profissional de CTI é referido genericamente como intensivista, pois há uma identidade comum a todas as categorias profissionais.

2 Às vezes, ela conta também com um estagiário de psicologia.

3 Esta fala revela um aspecto central referente ao cuidado médico: sobre qual 'doente que realmente mereceria ser salvo', o que será discutido adiante.

4 A imagem do cirurgião no meio médico é a de um especialista, considerado por seus pares acima de outras especialidades clínicas, com alto grau de onipotência. 



\section{4 \\ Difíceis Decisões}

Valeu a pena? É tão difícil responder... Cada circunstância, cada situação, cada momento, colocam respostas diferentes, às vezes difusas, confusas, duvidosas. Não é necessário responder de imediato, mas sim refletir. Pensei nisso tantas vezes... Tantas mortes motivaram novamente a questão que agora posso e devo escrever sobre ela para tentar elucidar se aprendi algo com toda esta experiência.

(Allué, 1998) ${ }^{1}$

De acordo com reportagem do Jornal do Brasil (4 de abril de 1999, p.21), levantamento efetuado pelas secretarias estadual e municipal de saúde revelou que a cidade do Rio de Janeiro conta com 238 leitos de CTI, considerando-se a rede pública de hospitais de emergência federais, estaduais e municipais. A relação é de um leito para 23.244 mil habitantes, em uma população estimada em cerca de cinco milhões e quinhentos mil habitantes. Pablo Vazquez, coordenador da Câmara Técnica de Terapia Intensiva do Cremerj, declarou, na reportagem: "a falta de leitos de terapia intensiva é uma forma de controle social pela falta de assistência médica. É como uma câmara de gás. Estão morrendo pessoas que não deveriam morrer".

O CTI pesquisado, inserido em um hospital de grande porte com cerca de 500 leitos, é uma unidade capaz de prestar assistência simultânea a no máximo sete doentes. No caso de agravamento do estado de um paciente, com indicação de internação urgente no CTI, pode não haver disponibilidade de vaga. O intensivista tem consciência dessa relação desigual entre demanda e oferta, em que a falta de vaga para internação poderá excluir alguém da possibilidade de cura ou de vida. Diariamente há solicitações de vagas por parte das diversas enfermarias do hospital, que são transcritas no quadro da sala de reunião. Durante todo o período de observação, em nenhuma ocasião havia menos de dois pedidos - em geral de urgência e extrema gravidade -, chegando até a oito ou dez solicitações diárias. 
A equipe intensivista preocupa-se com essa questão, como disse um médico plantonista: "Provavelmente quando vagar um leito a maior parte desses pacientes que aguardam vaga já terão morrido, sem a assistência que o CTI poderia prestar".

Em entrevista ao Jornal do Cremerj, Sérgio Rego, da Sociedade Brasileira de Bioética - Regional Rio de Janeiro -, discorre sobre a responsabilidade do médico na tomada de decisões concernentes à vida do doente internado em UTI. Rego considera que:

São muitos os fatores que podem interferir na decisão do médico em reanimar ou não o paciente. Podem ser fatores culturais e até mesmo de pressão do hospital em desocupar o leito para colocar outro paciente... A bioética possibilita uma discussão sobre esse assunto, na medida em que considera que não existe mais um único princípio aceito por todos e permite que outros princípios morais aflorem com base em uma realidade mais ampla. (Rego in Jornal do Cremerj, abril 1999. p.13)

Decisões são tomadas diariamente pelo intensivista: internação, escolha de medicamentos, uso da aparelhagem, culminando com a reanimação ou não de um paciente. O médico angustia-se com tais responsabilidades e tem clareza de que decide baseado em fatores de distintas ordens: técnicos, sociais e morais. Em entrevista, no dizer de um médico plantonista:

Sabe, sobre o problema da eutanásia, acho muito difícil decidir quando parar de trabalhar. Acho uma coisa complicada, ainda mais em CTI: quando parar de tratar o doente? Dificílimo. Nós só podemos parar de tratar um doente quando tiver base científica de morte cerebral. Eu li uma reportagem e achei fantástico e coloquei isso na minha cabeça. Você não deve parar porque você começa a ficar como Deus, começa a ficar se achando Deus. E começa a entrar coisas em você, coisas que traz inconscientemente. Você começa a parar de tratar porque aquele doente é judeu ou porque aquele é negro, ou ainda porque é pobre. É complicado se não tiver uma base científica.

O médico demonstra a necessidade de se basear em critérios tanto técnicos, advindos do campo do saber médico, como éticos ou bioéticos. Durante o período de pesquisa, alguns critérios - explícitos e implícitos - foram sendo evidenciados, de forma a constituir um 'sistema' semi-organizado de classificação dos pacientes, a partir do qual o intensivista assume determinadas posturas e decide condutas. Essa classificação não é um sistema no sentido clássico de uma totalidade. É antes um sistema móvel, em que as categorias não são auto-excludentes nem estáticas, de modo que os doentes podem ser qualificados de distintas formas simultaneamente 
e podem ser reclassificados ao longo do tempo de internação. Cabe mencionar que a sistematização - mais ou menos organizada - dos 'tipos' de doentes não é restrita a esse CTI e também ocorre em unidades semelhantes e em outros serviços hospitalares.

Becker (1992: 313), em pesquisa etnográfica sobre a aprendizagem médica, apresenta um sistema classificatório dos pacientes, elaborado por estudantes. As classificações derivam da cultura médica, na qual se incluem os doentes "pitiáticos", os "obesos", os "perigosos" (em relação ao contágio); da cultura leiga, incluindo as valorações vinculadas às condutas sexuais e à faixa etária dos pacientes; e as da cultura estudantil, na qual os casos são qualificados como 'interessantes' ou não ao aprendizado. Josep Comelles (1994: 195), em seu estudo sobre uma Unidade de Cuidados Intensivos de Grandes Queimados, também observou a categorização do internado segundo sua resistência física: os que não morrem e seguem "agüentando" (ou resistindo), em contraposição aos "que se deixam levar"; e segundo seu comportamento com relação ao uso do respirador: o "que rebela" e o que se "adapta".

\section{Entre o Social, o Institucional e o Biológico}

Desde a primeira observação, o médico plantonista apresentava dados dos doentes internados, como idade, patologia e o estado geral em que cada um se encontrava. Algumas categorias apareciam nas referências feitas aos pacientes como, por exemplo, 'morredores', contrapostos aos 'que apresentaram boa resposta terapêutica'. Ao longo do tempo de observação, a repetição e a uniformidade das referências aos pacientes evidenciou o 'sistema' classificatório - não explícito - construído pela equipe.

$\mathrm{O}$ 'sistema' classificatório é fundado basicamente em três eixos. O primeiro núcleo de categorias comuns funda-se genericamente em uma ordem técnica, avaliável pelo saber médico. Passo a denominá-lo de eixo de 'viabilidade', ao qual pertencem categorias como 'viável', 'inviável', 'responsivo', 'highlander' e 'morredor'. O eixo de viabilidade é referido ao saber médico, sendo as referências biológicas extremamente relevantes. ${ }^{2} \mathrm{O}$ segundo eixo é regido por atributos sociais, indicando a posição do indivíduo em contexto social mais amplo e sua inserção na instituição. Passo a nomeá-lo de eixo 'social' e abarca categorias como 'anônimo', 'vip' e 'estigmatizado'. O terceiro eixo também se funda em características sociais, referido à dimensão das normas e regras relativas ao comporta- 
mento de um doente internado no CTI. As categorias 'cooperativo' e 'rebelde' são constituintes deste eixo - o 'institucional'. ${ }^{3}$

Em cada eixo há categorias valoradas positiva ou negativamente pelos profissionais. Certas classificações refletem a imagem positiva que os intensivistas têm de si e de seu trabalho, enquanto as valoradas negativamente denunciam os limites de sua prática. Ao enquadrar um paciente em uma determinada categoria, o profissional inicia inconscientemente um processo decisório. Tais classificações ordenam simbólica e praticamente a tomada cotidiana de decisões que constituem o modo mais visível da prática profissional médica. Isto é, de que forma se expressa a conjugação entre um certo tipo de saber, conhecimento sobre o corpo, sobre o adoecimento e a possível cura - e o poder, as formas de prestígio e autoridade que tal conhecimento ensejam.

Passo a descrever o modo de operação dessas categorias, o que conduz, na prática dos profissionais de CTI, à expressão de seu saber e poder. As situações de dificuldades e conflitos para a equipe são apresentadas, nas quais são revelados aspectos relativos à dupla dimensão constituinte da prática médica. O delicado equilíbrio entre competência técnica e cuidado está presente no processo decisório, no qual o 'sistema' classificatório é uma referência relevante.

\section{Paciente 'Ideal': 0 brilho do intensinista}

A primeira condição a ser atendida para que um paciente seja aceito pelo CTI é sua 'viabilidade': qual caso detém maiores possibilidades de benefício com a internação no setor. A demanda de vagas por parte das enfermarias do hospital é constante. Quando surge uma, um médico-residente R3 ou plantonista é encarregado de avaliar o estado dos doentes para selecionar quem será transferido para o CTI. De acordo com um médico plantonista, existe um índice médico denominado Apache (Acute Physiology And Chronic Health Evaluation), para avaliação do prognóstico do paciente - referência mais comumente utilizada no acompanhamento do doente internado, relacionado à 'resposta terapêutica'. No CTI pesquisado, segundo o mesmo médico, é utilizado como parâmetro de avaliação do funcionamento da unidade. No entanto, nenhum critério 'objetivo' de viabilidade é ali formalmente adotado e a discussão sobre os casos é recorrente. A fala da médica responsável pela rotina é esclarecedora: 
Não tem critério absoluto, como estou te falando. Não tem papel, e isso você não vai ter em lugar nenhum. Mais de oitenta anos não interna, não está lá, isso não existe. Critério de doença? Também não existe. E até é uma coisa difícil... Entendeu, então é uma questão de bom senso, e isso é complicado.

O critério de possibilidade de resposta terapêutica fica a cargo do 'bom senso' do profissional, o que, embora certos quesitos integrem o que é definido como tal, provoca uma grande margem de subjetividade. De certa forma, há regras consensuais não necessariamente conscientes para os distintos profissionais. Muitas vezes discordâncias surgem e, geralmente, o intensivista mais experiente tem avaliação distinta de seu colega com menos tempo de prática. Um bom exemplo é oferecido pela seguinte situação: para apenas um leito vago havia dois pedidos de internação para homens na mesma faixa etária, em torno dos quarenta anos. Uma discussão se estabeleceu entre dois médicos: o profissional mais jovem insistia na exclusão de um dos pacientes, com Aids, enquanto sua colega, com mais tempo de prática clínica, percebia chances iguais de recuperação em ambos os casos. A situação exigia uma difícil definição, como disse a médica durante a discussão: "É uma escolha de Sofia". ${ }^{4}$

A expectativa de vida parecia ser um dos parâmetros em jogo, avaliada também sob o prisma do estigma da doença, o que, aliás, se fez presente por todo o tempo de internação desse doente. Um médico plantonista se referia jocosamente a ele como "nosso garçonzinho promíscuo". 5 O parâmetro referente à expectativa de vida ficou evidente também durante o tempo de internação. Ao surgir um pedido de vaga para um menino de 12 anos, um médico intensivista expressou seu desejo da seguinte forma: "Se o paciente do isolamento resolver ir logo, aí abre mais vaga. Esse aí não vai durar muito mesmo, já está cinza azulado, podia ir logo e resolvia o problema de vaga".

Tal situação ilustra a importância de certas referências, como idade e o tipo de patologia entre os critérios não-explícitos adotados pela equipe intensivista. Uma hierarquia etária se apresenta claramente: quanto mais jovem o doente, maior o interesse e investimento dos profissionais do CTI. Como disse uma residente sobre os critérios de internação: "tem que pesar a idade". No dizer de um médico plantonista, quando indagado sobre o ‘tipo' de paciente prefere lidar:

Se tivesse de escolher um grupo, tenho preferência por trabalhar com pacientes mais jovens. Não que eu ache que os pacientes mais idosos sejam mais dificeis, mas é uma questão talvez até porque o mais jovem é um paciente que te gratifica mais. É um paciente que, se você consegue 
que ele tenha alta, você se sente mais realizado. Você acha que foi mais útil pra ele.

O trabalho do intensivista é mais valorizado quando se trata de indivíduo mais jovem, como explica em entrevista o mesmo médico, referindo-se à sua preferência por doentes mais jovens: "Se essa senhora de oitenta anos sair daqui, a perspectiva de vida dela é o que? Mais dois anos? Mais cinco anos? Dificilmente ela vai sobreviver mais que isso".

Aparentemente, a avaliação do profissional é quantitativa, referida ao tempo possível de produtividade social do indivíduo. O intensivista considera seu trabalho mais ou menos útil de acordo com o tempo provável de sobrevida. O idoso é desqualificado por alguns intensivistas, que se referem a ele como 'vovô' ou 'vovôssauro'.

Em uma observação, havia um leito vago e várias solicitações de internação no CTI. Um plantonista dirigia-se às enfermarias para avaliar os casos 'viáveis', quando uma médica recomendou: "Por favor não invente de trazer uns vovôs prá cá, já chega de vovô". A hierarquia etária é presente cotidianamente no setor, como no dizer de uma médica: "Às vezes até não gosto de trabalhar com o idoso. Porque a impressão é que é um trabalho perdido. É um gasto muito grande e além de tudo é um sacrifício muito grande pro doente".

Na sociedade ocidental contemporânea, com a valorização do corpo, em especial do corpo são, vigoroso, ágil e sexualizado, a velhice incomoda - e é conseqüentemente desqualificada -, por sua inexorabilidade e proximidade da morte. A equipe médica reproduz assim os significados mais amplos conferidos à velhice e ao envelhecimento. Para o intensivista trata-se de um equilíbrio entre custo e benefício, no qual o sofrimento do próprio doente e de sua família, bem como o provável tempo de vida útil são levados em consideração. Quando se trata de uma 'escolha' de investimento entre dois casos, em geral a equipe demonstra maior mobilização perante um paciente mais jovem, como disse, angustiado, um residente diante de um pedido de vaga para um jovem de 16 anos: "Bem que podia acontecer uma desgraça com o senhor do leito 4. Ele podia ter uma acidose daquelas que a gente não consegue controlar e... Seria uma desgraça para ele e um bem para esse garoto que precisa da vaga".

A fala é ilustrativa da preferência do profissional, pois o doente do leito 4 tinha cinqüenta anos. Em outra ocasião, durante a 'visita', a médica responsável pela rotina disse, referindo-se a um menino de 12 anos internado: "É um garotão, vamos dar uma forcinha e acabar com esse stafilo". Tais incentivos e estímulos 
eram raros nas 'visitas' e, quando presentes, em geral referiam-se a pacientes bem jovens.

A mobilização emocional da equipe é consideravelmente maior quanto mais jovem for o doente. Comelles (1994) também se refere a esse aspecto, em relação aos argumentos que evidenciam os limites da couraça profissional: "querem trazer para este serviço as crianças queimadas e não creio que possa resistir. Posso trabalhar com adultos, mas com crianças... me causam muita pena, pensaria que são meus filhos" (Comelles, 1994: 192).

Apesar da clara predileção evidenciada na observação, nas entrevistas não houve nenhuma resposta em que a idade fosse apontada como fator relevante na indicação de internação. As recomendações foram semelhantes: doente grave necessitando de atenção e cuidados intensivos, monitoração cardíaca e respiratória, além de pós-operatório. A única contra-indicação referia-se ao doente grave terminal, por não ter chance de recuperação. No dizer de uma enfermeira:

Ele precisa estar com risco de vida, mas com prognóstico. Quer dizer que valha a pena o investimento, não é bem valer a pena. Você não deve internar um paciente com um quadro terminal de uma doença. Quer dizer, você vai dispor de um custo hospitalar, de tecnologia, de profissionais, e você não vai devolver esse paciente pra sociedade. Então é um investimento pra nada na verdade.

Entretanto, o profissional tem clareza de que lida, em sua prática, com uma margem de incerteza em que os riscos são possíveis a partir de cada decisão tomada.

Há alguns anos atrás aqui no hospital eu mesma vi uma doente na Pneumologia. Era uma doente com DPOC grave, obesa, que já tinha entrado em prótese lá. Ela estava no respirador e não me lembro se tinha vaga ou não no CTI. Considerei a doente fora de prognóstico, fora de plano terapêutico. Escrevi isso lá embaixo e não trouxe a doente para o CTI. Eu acho até que tinha vaga, não me recordo. Posteriormente alguém depois de mim foi e trouxe a doente para o CTI. Essa doente ficou bem, saiu do CTI, teve alta hospitalar e foi pra casa. Não sei quanto tempo ela ficou viva. (médica responsável pela rotina, em entrevista)

O processo de tomada de decisões da equipe é iniciado com a seleção do paciente 'viável' e, com base nisso várias situações podem surgir, cada uma demandando novo posicionamento dos profissionais. Em seu trabalho, a equipe objetiva salvar uma vida, combatendo a doença que a ameaça, de modo que o esperado e desejado é que o enfermo apresente uma boa resposta terapêutica, melhore 
e tenha alta do CTI. O doente 'viável', ao apresentar uma resposta positiva no curso de internação, passa a ser nomeado de 'responsivo'. ${ }^{6}$ É aquele que mais gratifica a equipe, por reiterar seu saber técnico e competência. Ao longo do período de pesquisa vários indivíduos tiveram suas vidas salvas nesse CTI e alguns retornaram à unidade para visitar a equipe e agradecer seu desempenho. A alegria e o afeto eram os sentimentos predominantes em tais encontros. Durante uma 'visita', todos os presentes comentaram sobre um doente que esteve internado. Ao ter alta hospitalar, dirigiu-se ao CTI para se despedir e agradecer o trabalho e a dedicação. "E eu disse pra ele que ele deu muito trabalho mesmo", comentou uma médica. Todos os presentes riam e brincavam, comentando com orgulho e satisfação: "Ninguém dava mais nada por ele e ele acabou saindo".

O paciente 'responsivo' reitera o valor do trabalho do intensivista, reafirmando seu saber e poder diante da morte, como disse, em entrevista, uma enfermeira: "Uma das coisas que mais me gratifica, em termos de terapia intensiva, é quando o paciente sai daqui e depois ele volta pra dar um tchau porque ele está indo pra casa. Ele vem aqui pra agradecer. Vale a pena continuar batalhando".

Muitas vezes a família do doente que obteve alta desempenha importante papel no reconhecimento do trabalho da equipe intensivista. Durante a observação, o setor recebeu um vaso com flores da família de uma moça que esteve internada, com uma carta agradecendo o tratamento e a dedicação dispensada pela equipe do CTI. A carta finalizava: "desejando que as flores sirvam para embelezar, enfeitar e alegrar um ambiente onde pessoas tão atenciosas trabalham sem descanso".

As demonstrações de reconhecimento, por parte dos pacientes e familiares, propiciam uma valorização do intensivista. Como disse um residente, referindo-se a um paciente que esteve muito grave e melhorou, chegando à alta hospitalar: "Ele ressuscitou, nasceu de novo". O profissional de CTI reúne recursos técnicos que, de certo modo, fazem com que ele se equipare a uma entidade superior toda poderosa, passível até de 'devolver' a vida a quem quase não a tinha mais. O saber e o poder do intensivista são reafirmados pelos doentes 'viáveis' e 'responsivos'.

Contudo, essas não são as únicas possibilidades de classificação dos internados. A posição social do indivíduo também é relevante. Há, decerto, um discurso igualitário no CTI, como prova uma auxiliar de enfermagem entrevistada: "Aqui não importa se vem um professor não sei de onde, o pai, a mãe da deputada. Não importa quem é o paciente. Importa que é um paciente. O tratamento é igual, não tem diferença se é o lixeiro que vem aqui. Não tem diferença". 
Na prática, a equipe se mobiliza diversamente de acordo com a situação social dos internados. O 'ideal', segundo os informantes, é o paciente 'anônimo', aquele que não possui inserção social de destaque nem 'conhecimentos' na instituição que o coloquem em posição especial. A equipe afirma ter maior facilidade em lidar com essa pessoa e sua família, como disse a psicóloga do setor:

As famílias mais difíceis são as famílias que têm um poder aquisitivo melhor. Porque elas vêm com muita arrogância, com muita desconfiança, com um comportamento como se elas não precisassem disso aqui. Elas vêm impondo, querem determinar as coisas.

O doente 'anônimo', assim como sua família, em geral não questiona as decisões da equipe, nem possui laços sociais - institucionais ou não - com poder de interferência junto aos profissionais. Desse modo, é um paciente que não confronta o saber da equipe, não interfere em suas decisões, resigna-se em aceitá-las.

Há uma outra forma de classificação do internado, originária da lógica institucional, referente à sua conduta durante a internação. Trata-se do paciente 'cooperativo', definido da seguinte forma por um médico-residente: "Um cara legal, calmo, tranqüilo, não reclama de nada, bonzinho, coopera”. O 'cooperativo' é o doente que se conduz de acordo com o idealizado pela equipe intensivista, submetendo-se sem queixas às manipulações e procedimentos invasivos no corpo. A equipe considera que o paciente 'cooperativo' facilita o trabalho:

O mais fácil de trabalhar é aquele que não é ansioso. Tem paciente que é calmo, então você consegue levar bem o desmame, explicar a ele o quanto é importante aquele momento. Esses doentes orientados e tranqüilos são mais fáceis de lidar, porque no desmame é importante que o paciente seja cooperativo. (fisioterapeuta-residente)

A respeito desse tipo de paciente há mais um aspecto importante para os profissionais: o estado de consciência em que a pessoa se encontra. Segundo um estagiário de medicina, "mais fácil é o paciente que está todo sedado. Porque ele não está falando nada". De acordo com os intensivistas, o 'ideal' é o enfermo que não tem condições de expressão, e, caso a tenha, que 'saiba' se comportar de modo a não interferir no trabalho terapêutico. Dentre os profissionais com quem mantive contato, houve uma única exceção a esse respeito, a psicóloga, a única intensivista que disse preferir lidar com indivíduos acordados e lúcidos:

Os pacientes mais fáceis são os que falam. Primeiro, os que falam. Segundo, os que podem se comunicar com mais facilidade, mesmo traqueostomizados, mas tendo a boca livre, fazendo uma mímica labial 
ou aqueles que conseguem escrever. Eu acho que os pacientes mais fáceis são os que estão acordados. Talvez seja o contrário do que a equipe responda pra você. Pra eles eu imagino que seja o paciente sedado.

A comunicação é valorizada apenas por um tipo de profissional, e por isso mesmo fica limitada a ele. O trabalho da psicóloga no CTI, que conversa sempre com os internados, mesmo quando sedados ou inconscientes, é baseado na escuta e expressão dos sentimentos. Como já dito, trata-se do único membro da equipe do CTI que não utiliza qualquer mediação tecnológica para desenvolver seu trabalho. Para outros intensivistas, a aparelhagem ocupa um lugar de especial importância, algumas vezes servindo como 'facilitadoras' das tarefas a serem desempenhadas, como disse, em entrevista, uma auxiliar de enfermagem:

Eu prefiro o doente entubado, mesmo acordado, com sondas, com fios, com isso e aquilo. Eu particularmente prefiro com tudo. Você fica preso à aparelhagem, sabe. Com monitor hemodinâmico, no respirador, então eu passo sonda, controlo no monitor.

A organização do trabalho objetiva a maior eficiência técnica possível, o que algumas vezes conduz a uma contraposição entre competência técnica e cuidado. O intensivista prioriza os parâmetros de funcionamento dos órgãos dos pacientes e os resultados dos exames. Em sua formação profissional incorporou a preeminência dos valores relativos ao conhecimento, à técnica, e à ação competente sobre os valores das relações, da compaixão e da empatia. À eficiência cabe um lugar privilegiado, em contraposição ao cuidado 'não-técnico', à escuta possível em uma relação humana. De acordo com uma enfermeira,

É muito difícil o paciente acordado porque a gente está acostumado a lidar com estados de gravidade, onde você tem que fazer bem em tempo hábil. Aquela coisa toda cronometrada, uma equipe atrás da outra, junto com a outra. Quando o paciente está acordado ele pode dizer não, agora não quero. E é mais difícil assim porque, mesmo que ele tenha um quadro clínico de gravidade, ele, como ser humano, tem que ser respeitado antes de tudo. Ele pode dizer o que quer, o que não quer. Então é um espaço que você abre na terapia intensiva pra ele. Esse aí é diferente. Esse aí eu não vou simplesmente usar o meu poder. Quando a coisa é muito técnica é muito mais fácil. É o teu saber técnico.

A rotina do CTI é pautada prioritariamente pelo saber técnico, e o doente 'ideal' é o que se submete ao poder do profissional nas diversas etapas do tratamento. Segundo uma enfermeira, 
O paciente mais difícil de lidar é aquele paciente na terapia intensiva que está lúcido, orientado no tempo e no espaço. E com capacidade pra falar. É mais fácil aquele que você não precisa interagir. É mais fácil porque aí você age simplesmente com o teu conhecimento teórico. Você atua em termos técnicos, de desenvolvimento de técnica.

A rotina das equipes se organiza para maximizar a utilização dos recursos técnicos, silenciando a expressão emocional dos profissionais, doentes e familiares. Lidar com emoções e sentimentos dos pacientes e familiares pode demandar um tempo e uma mobilização afetiva dos profissionais, mencionados por eles como 'interferências' ao bom andamento de seu trabalho.

O doente 'ideal', além de 'viável', 'responsivo', 'anônimo' e 'cooperativo', é o indivíduo que por suas características sociais e atributos pessoais, é suficientemente próximo da equipe de modo a causar certa empatia, possibilitadora de motivar seus cuidados, e suficientemente distante para não produzir na equipe uma identificação maior. É essa posição que faz com que a relação equipe-paciente se situe em limites emocionais 'adequados'. Como disse, em entrevista, um médico plantonista: "O paciente mais difícil é aquele com quem você se identifica", indicando a necessidade de um certo afastamento emocional para lidar com o enfermo. No mesmo depoimento desse médico: "A gente tem que se defender. A gente cria defesas pra se distanciar". Para que o intensivista possa exercer sua competência técnica da melhor forma, deve construir barreiras impeditivas do contato com seus sentimentos e emoções, para não interferir nas suas decisões e não afetar sua prática.

Em síntese, o doente considerado 'ideal' pela equipe é aquele que 'responde' à terapêutica conforme o esperado, é dócil e submisso às normas e regras implícitas de comportamento, e cujos atributos sociobiológicos, como a idade, não têm o poder de produzir uma identificação radical, a ponto de 'interferir' nas decisões tomadas pelos profissionais. O brilho do intensivista pode então ser revelado por intermédio dele, demonstrando a eficácia do seu saber.

\section{Paciente 'Difícil': os limites do Poder do Intensivista}

A equipe do CTI prefere lidar com o internado que se aproxime do 'ideal', mas nem todos reagem ou se comportam de acordo com esse modelo. Quando isso ocorre, são classificados como casos 'difíceis'. 
O 'ideal' é o paciente 'cooperativo', que se conduz de acordo com as normas implícitas de conduta. $\mathrm{O}$ 'rebelde' é o seu oposto: não aceita os tubos e fios em seu corpo, a ponto de por vezes tentar retirá-los, não se sujeita às manipulações ou ao uso da aparelhagem. Em uma observação, presenciei o despertar de um senhor de cerca de setenta anos. Ao perceber o paciente movimentando braços e mãos, um enfermeiro solicitou ao residente de enfermagem amarrá-las, pois "ele pode acabar tirando o soro e os aparelhos". O profissional considerou a movimentação corporal do paciente um risco à correta posição dos fios e tubos conectados a seu corpo. $\mathrm{O}$ enfermeiro amarrou seus braços à grade do leito, classificando-o como 'rebelde'. Pouco depois uma enfermeira conversou com o doente, explicou-lhe as consequiências da desconexão da aparelhagem com a movimentação e soltou seus braços. Esse exemplo demonstra que a classificação do internado como 'rebelde' depende da disponibilidade - objetiva ou subjetiva - do profissional. Em outra ocasião, o mesmo senhor teve suas mãos novamente amarradas por outro intensivista, e reclamou com a fisioterapeuta que o atendia.

Pois o senhor fez arte, ficou mexendo a mão, aí o aparelho saiu. $O$ senhor não deixa a gente cuidar do senhor. Se não fizer mais arte, depois a gente tira a faixa da mão. Nós estamos aqui para cuidar do senhor, e vamos fazer exercício. (fisioterapeuta)

A movimentação expontânea é percebida pelo profissional como uma recusa do doente a se 'deixar cuidar', contrapondo-se ao tratamento. A linguagem utilizada pelo intensivista lembra a de uma professora de jardim de infância, infantilizando o paciente e indicando a postura pedagógica em relação às normas institucionais.

A perda do status de adulto desse paciente é clara no diálogo, em que há uma inversão da hierarquia social usualmente vigente, já que a fisioterapeuta tinha idade para ser sua neta. Ao ser internado no CTI, o indivíduo sofre uma série de perdas relativas à sua vida como um todo. A trajetória do doente internado nessa unidade é comparável a de outros internados em instituições totais. Esse mecanismo, entre outros, faz parte do que Goffman (1972: 133) nomeou de "carreira moral" do doente internado. $\mathrm{O}$ autor refere-se à carreira moral do paciente mental, mas é possível a comparação com a carreira moral de um internado em qualquer instituição total, pois o CTI pode ser considerado uma instituição total.

Ao ser confrontada por um doente 'rebelde', a equipe promove alguma forma de controle: sedação medicamentosa ou contenção física. Esta última pode ser realizada amarrando os braços e/ou pernas nas grades do leito ou utilizando uma luva sem dedos, com a mão totalmente enfaixada. O corpo da pessoa enferma torna-se 
um campo de batalha na disputa de poder, em que a equipe, visando o tratamento, a manutenção da vida e a preservação de sua identidade profissional, deve se impor. A 'cooperação' significa sujeição: diante da 'rebeldia' algumas vezes ameaças são feitas, a exemplo de uma médica durante a 'visita', referindo-se a um paciente que arrancou o tubo do respirador: "É bom ele saber que se ele não colaborar terá que ser entubado novamente. Eu vou lá bater um papo com ele, vou avisar ele de que é bom ficar calminho, senão vou entubar ele de novo. Senão ele morre sem o tubo" (médica staff).

A 'rebeldia' refere-se algumas vezes à aparelhagem, e expressões como 'brigar com a máquina' ou 'não aceitar o respirador' são freqüentemente utilizadas pela equipe. Paradoxalmente, o doente que não aceita a retirada do tubo do respirador pode se tornar um problema, o que fica claro na fala de uma residente de fisioterapia, ao 'passar' os casos para sua colega: "O paciente do leito 1 não quer nada... A gente quer começar a tirá-lo do respirador, ele está dependente e preguiçoso". A retirada do uso do respirador é nomeada de 'desmame'. É interessante a escolha dessa denominação, que aponta um processo regressivo do paciente.

O tempo é um importante fator na 'rebeldia', talvez até um critério presente na classificação. Ao se 'rebelar', o enfermo demanda um tempo maior por parte dos profissionais - um tempo para o seu convencimento ou para a contenção de sua 'rebeldia'.

A cada etapa do tratamento, há um comportamento esperado pela equipe, que reage de maneiras distintas às alterações das condutas dos internados. Um paciente 'rebelde' pode se tornar 'cooperativo', como um senhor de cerca de 75 anos, sedado, ao ser assim classificado. Pouco depois entrou em uma fase de depressão. Os profissionais, que antes dirigiam-se a ele em voz alta, algumas vezes em tom de reprimenda, passaram a falar baixo e carinhosamente.

A 'rebeldia' é uma dificuldade pertencente ao 'eixo institucional' de organização das categorias classificatórias. No 'eixo social', o ideal para a equipe é o doente 'anônimo'. Em contraposição ao 'anônimo' há duas possibilidades classificatórias: o 'vip' e o 'estigmatizado', ambas produtoras de mobilização para os profissionais. O paciente 'vip' situa-se no plano das relações institucionais e pessoais, ou seja, do 'conhecimento', como por exemplo, o caso ocorrido durante a observação do filho de uma antiga funcionária do hospital. A indicação de internação no CTI é preencher as vagas com pedidos de dentro do hospital e, só depois, buscar atender aos pedidos externos. No entanto, 'jeitinhos' podem ser dados, especialmente ao se tratar de pessoa que tenha relação com certas instâncias de poder institucional. ${ }^{7}$ A equipe mobiliza-se com a internação desse tipo de 
doente, como disse um médico plantonista: "Ah, paciente vip dá um trabalho, tem tanta gente se metendo". Algumas vezes há cobranças e interferências por parte dos 'conhecidos' do paciente em relação aos cuidados a ele prestados. Geralmente são abertas exceções às regras e normas, como, por exemplo, a dilatação do horário de visitas. A família do enfermo 'vip', por ter um acesso facilitado ao setor, muitas vezes demanda maior atenção dos profissionais, o que gera uma tensão adicional em seu trabalho. Como disse uma médica a respeito da 'interferência' dos familiares de um doente 'vip': "É dose, como as famílias interferem no tratamento dos pacientes". Com base nessa situação, a equipe procura colocar o internado em condições de alta o mais rápido possível, como disse uma médica a respeito de um doente 'vip', parente de um alto funcionário do hospital: "O negócio é tratar bem para ele sair logo, e voltar para terrinha dele. Vamos tratar bem dele..." (médica staff).

Parece que o 'tratar bem' expresso pela intensivista significa uma dedicação maior do que a usual, tendo em vista a pressão externa exercida sobre os profissionais. A única valoração positiva do doente 'vip' é que, ao melhorar, pode produzir um reconhecimento da qualidade do trabalho da equipe intensivista, por parte de instâncias superiores. Por ocupar um lugar 'especial', o internado 'vip' pode produzir irritação na equipe e contradiz o discurso formalmente igualitário vigente no CTI.

Essa não é a única possibilidade de contraposição ao ideal do anonimato, pois enquanto o 'vip' tem uma identidade social, digamos, excessivamente positiva, o 'estigmatizado' é desvalorizado por seus hábitos. O estigma pode se dar pelas práticas alimentares, opções e práticas sexuais ou pelo uso de drogas legais ou não. Um estagiário de medicina, quando entrevistado, disse, a respeito da 'culpa' no adoecimento em virtude de 'maus-hábitos':

Tem doença que o paciente é culpado....Um paciente que é alcoólatra de muito tempo, ou o tabagista de muito tempo, ou o tipo de dieta. Aquele que faleceu há pouco tempo, era hipertenso, bebia demais, comia dieta hiperlipídica, enfim, ele tinha todos os fatores de risco.... Enfim, não justifica também eu não querer tratar dele, mas...ele poderia evitar alguma coisa disso.... Sabe, é diferente aparecer um câncer de pulmão em quem nunca fumou.

Certa ocasião, disse um médico a respeito de um paciente alcoólatra: "Parece que o álcool está grassando por aqui no CTI.... Esse paciente, do isolamento, a gente podia botar álcool direto no soro correndo para sedar ele (médico plantonista, rindo, dirigindo-se aos residentes). 
Em outra situação, após a confirmação de morte cerebral de um paciente de cerca de quarenta anos, uma médica-residente comentou: "Ele comia muita gordura, bebia, é nisso que dá... Muita alegria com pouco cuidado...”.

O indivíduo é considerado - por alguns profissionais - culpado por seu adoecimento, o que pode interferir na relação do intensivista com o enfermo e seus familiares. Do mesmo modo que, ao se identificar com o doente o profissional aproxima-se além da distância considerada ideal, ao desqualificá-lo, o afastamento torna-se igualmente problemático. Tal situação pode, em alguns casos, conduzir a um investimento menor por parte de diversos membros da equipe. Um episódio é ilustrativo. Um doente internado com Aids teve uma piora considerável, e um plantonista concluiu: "Provavelmente, o nosso garçonzinho promíscuo não passa de hoje". No dia seguinte, a respeito do mesmo paciente, uma médica, após examiná-lo, comentou: "Não vamos desistir desse doente, vamos tentar de tudo. Ele é jovem, tem um bom coração, está reagindo e pode ser salvo" (médica staff).

A expectativa do tempo de vida do paciente talvez tenha sido avaliada distintamente pelos dois profissionais, ao levar em conta o estigma sexual de sua doença. O primeiro profissional, que claramente desqualifica o doente, não consegue vislumbrar a possibilidade de melhora apresentada por sua colega. Retomando o que disse o plantonista citado no início deste capítulo, os preconceitos podem intervir nas decisões tomadas pelo profissional. Tanto o doente como a equipe estão inseridos na mesma sociedade, em que a doença funciona como significante social. A doença não é apenas uma interpretação coletiva partilhada pelos membros de um grupo social, mas também uma interpretação que expressa a relação do grupo com o social (Herzlich, 1986). A medicina pode, por meio do diagnóstico, da classificação e do tratamento das doenças, inscrever nos corpos os valores provenientes do social. Ela se torna, então, criadora ou legitimadora de determinadas valorações sociais. Dizendo com Herzlich (1986: 199): “O rotular de um estado como 'doença' não é um processo socialmente neutro, e a responsabilização médica se caracteriza pela estreita embricação da legitimidade e do estigma".

A maioria dos profissionais tem consciência de que, ao tomar uma decisão, muitas vezes baseiam-se não somente em seu conhecimento técnico, como em valores culturais, sociais e morais. Um episódio relatado em entrevista por um médico plantonista é ilustrativo. Respondendo sobre a autonomia do profissional no processo de tomada de decisões:

Nós tivemos um doente aqui que a gente decidiu parar tudo. Ficamos três dias parados, e ela não tinha morte cerebral. Nós tomamos esta decisão. Ela era AE, uma garota excepcional, grandona, teve uma 
febre e piorou muito. Isto tem uns dois anos, eu não esqueço. Paramos tudo numa segunda-feira, e na quarta-feira um médico decidiu voltar com tudo. Decidiu sozinho. Ele achou um absurdo terem parado e voltou com tudo. E não é que a menina voltou, acordou e saiu do CTI. Ela saiu falando, chamando o pai.

O excepcional é um indivíduo socialmente desvalorizado. É provável ter sido esse um dos fatores que concorreram para a decisão de a equipe interromper o tratamento. Em geral, esse tipo de decisão, por envolver grande responsabilidade do profissional, é tomada pela equipe em conjunto. Contudo, a vida dessa jovem - portadora de uma deficiência, e por isso estigmatizada - foi salva por uma iniciativa individual, o que indica a amplitude do poder do médico intensivista. Esse profissional não aceitou a classificação do caso, feita pela maior parte da equipe, como 'inviável'. Ao considerar a enferma 'viável', apesar de seu estigma, ele decidiu pelo investimento em sua vida. As categorias pertencentes ao eixo de 'inviabilidade' concentram os casos que representam o maior desafio para o intensivista.

A morte é uma presença contínua no CTI e os números são reveladores. Durante o período de observação foram internadas 54 pessoas enfermas, das quais 31 tiveram alta e foram transferidas para as enfermarias e 23 'chegaram a óbito'. Essa é uma indicação de que, por maior que seja a dedicação do intensivista, ele nem sempre consegue atingir sua meta. $O$ doente inicialmente qualificado como 'viável', ao não apresentar resposta terapêutica favorável, pode tornar-se 'inviável'. Os recursos técnicos, o saber e a competência do especialista são limitados diante desse casos.

Um internado no isolamento ilustra bem esse processo. Homem forte, com cinqüenta anos, internado com diagnóstico de tétano. A equipe investiu maciçamente no combate à doença: exames foram feitos a menores intervalos que rotineiramente, alguns materiais, como sangue e secreções, foram enviados para exame em instituições mais especializadas, consultou-se bibliografia com maior freqüência, em resumo, o controle e a vigilância habituais foram redobrados. Esse paciente era originário do interior do estado, tendo sido atendido em uma unidade hospitalar de sua cidade com poucos recursos. Seu caso era diariamente discutido nos mínimos detalhes. Entretanto, após algum tempo ele passou a não 'responder' ao esperado, o que provocou uma investigação maior de seu histórico desde a internação no outro hospital até o que havia se passado durante a transferência para o Rio de Janeiro, assim como todos os exames efetuados no CTI. Alguns dados foram então revelados: o doente sofrera duas paradas cardiorrespiratórias 
na ambulância. Em uma delas teria 'parado' durante um tempo suficiente para causar uma lesão cerebral. Um clima de desânimo se instalou na equipe com o laudo eletroencefalográfico de 'vida vegetativa'. Como expressou uma médica: “"será então que estamos fazendo tudo inutilmente?". O desinteresse tomou conta da equipe, o caso deixou de ser objeto de debates e tomou-se uma decisão: buscar equilibrar o estado do paciente, qualificado como 'inviável' e 'sem prognóstico', transferindo-o para uma enfermaria. $\mathrm{O}$ doente poderia ter ainda um tempo de vida - vegetativa - sem possibilidade de melhora. Como afirma Herzlich (1993a), logo que se admite que não há clinicamente 'mais nada a fazer', o médico cessa de alguma forma de ter responsabilidade sobre o paciente, que se torna apenas o ocupante de um leito.

Esse caso pertence à categoria 'inviável' do eixo de viabilidade. Nesse eixo também se incluem duas outras categorias: o 'highlander' e o 'morredor'. O paciente 'highlander', denominação muito freqüente em hospitais, referindo-se a um filme cujo herói é um guerreiro imortal, é aquele que, a despeito de todo o investimento terapêutico, não apresenta melhora nem piora durante um tempo prolongado. Em geral, o 'highlander' resiste, apesar da decisão médica de interromper o tratamento e a realização de exames. De acordo com os profissionais entrevistados, não há explicação científica para esse tipo de caso. O 'highlander' permanece internado por um tempo maior do que o usual, até que seu quadro se altere, passando a responder positiva - quando é reclassificado como 'viável' - ou negativamente, tornando-se um 'morredor'.

O 'morredor' é o paciente com vários sinais indicadores de morte próxima, sendo a constatação de morte cerebral um dado de extrema relevância. A confirmação de morte cerebral somente é possível mediante exame eletroencefalográfico, o que nem sempre pode ser feito, pois o hospital não possui aparelhagem portátil. Geralmente, o estado do doente é tão grave que a mobilização até outro andar do hospital para realização do exame constitui risco de morte. Nesses casos, a equipe efetua apenas uma avaliação clínica. ${ }^{8}$

Com base na classificação de um paciente como 'morredor', uma série de providências são tomadas: contato com o Banco de Órgãos para avaliação dos órgãos em condições para doação; a comunicação aos familiares do estado do doente e o pedido de autorização de doação; a seleção do próximo doente a ocupar o leito que ficará vago em breve. A equipe deve tomar uma decisão de central importância: que medicações e aparelhos devem ser mantidos até o óbito. Em algumas situações, como a que presenciei, pode-se optar por não mais utilizar medicamentos dispendiosos. O médico plantonista comunicou ao enfermeiro que 
a albumina pedida para a moça do leito 2 deveria ser guardada, "pois não é para usar um material tão caro para alguém que já vai morrer".

Os 'morredores' mobilizam muito a equipe e as reações variam de acordo com cada caso. Em geral, quanto mais jovem o 'morredor', maior a expressão de certos sentimentos da equipe, em especial o desânimo. Em uma das últimas observações, discutia-se o caso de uma moça de trinta anos, uma doente já conhecida dos intensivistas por já ter sido ali internada e ter apresentando boa resposta terapêutica. A sua reinternação provocou uma grande mobilização da equipe. Ela recebeu transplante renal, com resposta inicial positiva, mas naquele momento estava com uma infecção grave e alteração neurológica. Após a constatação da diminuição de sua atividade cerebral (segundo meus informantes, esse é um indicador de evolução para morte cerebral) a equipe ficou desolada. Os comentários eram de que seria um caso de "bom prognóstico, mas complicou", "que pena, estava indo tão bem", "fizemos tudo e não deu". Os rostos dos profissionais expressavam claramente o desânimo no contato com o irreversível, e a equipe permaneceu um certo tempo em silêncio. Subitamente surgiu uma conversa sobre trilhas musicais de novelas de TV e a maior parte dos intensivistas presentes começou a cantarolar e a contar piadas. Parecia não haver espaço nem palavras para expressar a tristeza dominante. $\mathrm{O}$ confronto com o limite do poder da equipe tornou-se insuportável.

Esse episódio faz pensar que a rápida passagem de um clima de desânimo para a animação é uma das formas preferenciais de gestão das emoções por parte da equipe. Uma outra forma de gestão das emoções refere-se à fragmentação do quadro apresentado pelo doente. Em uma ocasião, um fisioterapeuta disse, dirigindo-se a uma paciente, um caso raro, internada há mais de seis meses no CTI: "não entendo porque a senhora está chorando, seus parâmetros estão todos mantidos". Ao valorizar 'os parâmetros', o intensivista afasta-se dos sentimentos que surgem no contato com a pessoa internada.

O 'morredor' é a prova do limiar da ação heróica do intensivista e, muitas vezes, o profissional afasta-se do paciente agônico. A morte é, tanto para o médico como para o hospital, antes de tudo um fracasso (Herzlich, 1993a). Por isso, torna-se conveniente que a morte perca sua importância central e cesse de mobilizar recursos e energias, sobretudo nas atitudes cotidianas da equipe diante do agonizante. Assim se pode compreender a atitude da equipe diante do 'morredor'. Muitas vezes os profissionais falam e agem próximos ao leito do paciente como se ele não estivesse mais vivo. Em uma observação, duas auxiliares de enfermagem faziam a higiene de uma internada - com morte cerebral constatada por meio de 
eletroencefalograma - como se o seu corpo fosse um objeto inanimado. As profissionais conversavam em voz alta sobre assuntos triviais, como se a enferma não pudesse mais ouvir o que se passava à sua volta. Em seguida, duas médicas da Unidade de Transplante examinaram os olhos da paciente e conversaram com a médica do CTI sobre a retirada das córneas. Todas as conversas foram feitas junto ao leito e as referências eram feitas como se a moça não tivesse mais vida. Algumas vezes a equipe refere-se ao paciente ainda com vida, prestes a morrer, utilizando o tempo verbal passado. Os profissionais parecem atuar como se a morte já tivesse ocorrido. Tal situação é denominada por Sudnow (1967: 61) como "morte social", que precede a morte biológica.

A equipe busca, dessa forma, afastar-se do 'morredor' e das emoções despertadas em seu contato com ele. Muitas vezes os sentimentos emergem e são expressos sob a forma de 'humor negro', o que pode ser ilustrado pelo episódio observado. A equipe aguardava a morte de uma paciente - jovem, em torno de 16 anos - com diagnóstico de morte cerebral comprovado por exame eletroencefalográfico, tomando certas providências, como colocação de compressas para a melhor conservação dos olhos para uma eventual doação de córneas. Uma médica staff convocou estagiários e residentes de medicina para explicar o procedimento. A profissional perguntou ao grupo se já havia presenciado a retirada dos olhos de alguém recém-falecido. Com a resposta negativa, a médica passou a descrever detalhadamente sua primeira vivência:

Foi num plantão há muitos anos, de madrugada, umas três horas, um paciente chegou a óbito, chamamos a equipe do Banco de Órgãos e fiquei vendo para aprender. Estava tudo escuro nos corredores do hospital [o relato era acompanhado de sons como os utilizados em filmes de suspense e/ou de terror]. Na realidade não é necessário que se retire todo o olho, pode-se tirar apenas a córnea, mas é melhor tirar o olho para a conservação da córnea. Sabem como é o instrumento para tirar olhinhos? É um tipo de colherzinha. Em um minuto tiraram os olhinhos, faz um barulho quando sai, que nem quando se abre uma champanhe, ploft! [risos da médica diante dos protestos e pedidos dos jovens no sentido de que ela interrompesse o relato]. Ah, e vocês acham que acabou? Não, depois eles colocam a prótese e o defunto fica bonitinho, ninguém percebe no velório.

À reação dos profissionais mais jovens, a médica respondeu que "vocês têm que agüentar, se acostumar", deixando claro que provavelmente teria sido submetida a esse mesmo rito de passagem em sua trajetória profissional no 
confronto com a morte - rito este que estaria replicando com seus jovens aprendizes (Menezes, 2001).

O contato entre os profissionais e os familiares dos 'morredores' muitas vezes acarreta emoções, das quais a equipe busca um afastamento. Quando indagada sobre o que considera mais difícil em seu trabalho, uma auxiliar de enfermagem respondeu:

Pra mim o pior momento nessa terapia intensiva sempre foi e continua sendo o horário de visita. Eu sou obrigada a presenciar, mas se pudesse eu saía do salão nesse momento. Me deprime o sofrimento da família. Ainda mais porque eles são leigos, não sabem o que está se passando. E pior ainda quando a gente sabe que o doente vai morrer e a família tem aquela fé. A gente nunca quer que a pessoa querida vá embora. E a gente tem que dar aquela força pra pessoa, mesmo sabendo que é irreversivel.

Por intermédio da família do paciente 'morredor', muitas vezes a equipe entra em contato com o sentimento de perda, bem como com o limite de seu saber e de seu poder. Para um médico plantonista, "a coisa mais difícil é dizer pra família que o paciente morreu, provavelmente porque toda aquela onipotência acabou ali”. Não se trata mais de um corpo objeto de condutas e práticas técnicas, mas sim de alguém com uma família, com uma história - não apenas um histórico médico -, com um drama pessoal e social. Como disse, em entrevista, um médico plantonista: "Quando um doente entra no CTI, o médico, a enfermagem, toda a equipe se acha dona do doente. Aquela pessoa que até dez minutos atrás tinha uma família e filhos, acabou".

O poder e o saber do intensivista são confrontados por meio do contato com os familiares. O profissional, que até então lidava apenas com órgãos e funções, é forçado a entrar em contato com uma pessoa. A equipe geralmente funciona com certa indiferença afetiva ou afastamento emocional, o que pode ser compreendido como estratégia de distanciamento profissional. Em algumas situações, entretanto, no contato com os familiares, a equipe é confrontada e deve alterar sua estratégia. Isso pode ser exemplificado pela situação ocorrida durante uma observação, quando constatou-se a morte cerebral de uma doente de oitenta anos. Durante a reunião coordenada pela psicóloga, os médicos residentes comunicaram o estado da paciente aos seus familiares: uma filha, uma nora e dois netos. Ao compreenderem a proximidade da morte, as duas senhoras se abraçaram, chorando muito. Uma delas tremia e não conseguia se levantar da cadeira, enquanto a psicóloga amparava a outra. Uma médica-residente aferiu a pressão das duas e 
providenciou medicação, um indicativo de como o profissional lida com o sofrimento moral e emocional: ação técnica e intervenção medicamentosa. Parece que, para o intensivista, lidar com emoções é perda de tempo, especialmente ao se tratar de uma conduta 'inconveniente' do familiar. Talvez uma das formas que o intensivista encontre para conter sua angústia diante do episódio seja ancorar-se em sua identidade profissional e assim agir 'objetivamente'.

Após a saída dos familiares, alguns profissionais riram, fazendo os seguintes comentários: "Nunca vi ninguém ficar assim por uma sogra..." (médico plantonista); "Mas que ridículo, que situação mais constrangedora! Aquela senhora ficou chorando só porque recebeu a notícia da piora da paciente! Que coisa! Por acaso aqui no CTI é lugar pra essa choradeira!” (médica-residente).

O comentário da médica-residente demonstra que, para uma parte da equipe, não há espaço no CTI para manifestações de sentimentos. Durante uma observação, um médico-residente interrompeu a 'visita' com o anúncio da morte de um rapaz de 16 anos que já estivera internado no CTI em conseqüência de um erro médico em uma cirurgia. "Ele parou lá na enfermaria. E agora está lá a mãe do garoto, ela está lá histérica”. Esse episódio revela que até em uma situação de grande sofrimento - uma mãe perder um filho jovem - a referência do profissional se dá por um 'diagnóstico'. Em outra ocasião, uma mãe, ao receber a notícia de morte cerebral de sua jovem filha, percebendo o movimento de uma médica em direção ao armário de medicamentos, disse: "pode deixar, eu já tomei bastante Lexotan hoje... o que tenho a fazer agora é me despedir. Sabe, é triste uma mãe se despedir de uma filha". A mãe dessa paciente 'morredora' expressou com muita clareza dois aspectos. O primeiro refere-se à atitude, quase automática, do profissional no sentido de uma intervenção medicamentosa. $\mathrm{O}$ segundo está remetido à inversão da seqüência natural dos acontecimentos: o fato de um jovem morrer antes de seus ancestrais é, na sociedade ocidental contemporânea, particularmente triste, tendo em vista a valorização dessa faixa etária.

A rotina das equipes é organizada de forma a silenciar a expressão emocional dos profissionais, dos doentes e de seus familiares. Desse modo a morte, tão presente, é silenciada, banalizada, regulada e rotinizada. As palavras morte e morrer são evitadas e os eufemismos são largamente utilizados pela equipe intensivista: 'está descendo a ladeira', 'está indo embora', 'está no finzinho', 'não há mais o que fazer', 'está afundando', 'está entregue a Deus', 'não vai durar muito', 'parou, tentaram reverter e não deu', 'não vai passar de hoje', além de 'faleceu'.

Segundo Herzlich (1993a), a angústia é comumente presente no hospital, por maior que seja a indiferença ou a brutalidade das práticas da rotina hospitalar. 
A delegação de ter de tratar doentes que possam vir a falecer não fornece ao profissional os meios para elaborar uma conduta que os torne imunes a essa angústia. Um ônus se apresenta para o intensivista, como disse um médico plantonista: "O que cansa neste trabalho é o contato com a morte. É muita morte, é morte demais, isso vai cansando".

O cansaço e a mobilização do profissional fazem com que ele se distancie do moribundo e de sua família, o que não significa necessariamente indiferença. De acordo com Herzlich (1993a), a escolha de uma carreira médica não testemunha insensibilidade aos problemas do falecimento, mas revela, ao contrário, uma angústia inconsciente particularmente viva ante o mesmo. O trabalho médico e o funcionamento do hospital servem para reforçar o ocultamento social da morte e configurá-la de uma forma específica. Para Elias (1989) esse ocultamento da morte faz parte do impulso civilizador que se iniciou nas sociedades européias há cerca de quinhentos anos. Para o autor, as rotinas institucionalizadas dos hospitais configuram socialmente a situação do final da vida, criando formas de grande pobreza emocional, contribuindo para que o moribundo seja relegado à solidão (Elias, 1989). De fato, morre-se hoje nas instituições especializadas e o CTI é o setor hospitalar que apresenta grande concentração de 'morredores', como disse, no início de minha observação, um médico plantonista: "Semana passada foi uma carnificina: em sete dias morreram cinco doentes. Isso não é comum, não fica achando que é sempre assim".

Mas continuou 'assim' por algum tempo, como disse, mais tarde, uma enfermeira: "O paciente louco faleceu. A moça com lupus também. O paciente que era professor também. Depois internou outro doente no mesmo leito que ele e foi também".

E mais adiante, um médico plantonista disse: "Eu acho que pelo menos quatro desses doentes devem ir em breve: a senhora do isolamento, e os pacientes dos leitos um, três e cinco não devem demorar".

A morte é uma presença quase rotineira, o que leva o CTI a ser considerado, como disse a psicóloga, "um lugar assustador porque tem o estigma da morte. Todo mundo tem uma idéia do que seja o CTI e essa idéia está relacionada a alguma coisa assustadora, que é o limite - é o limite entre a vida e a morte".

A equipe responde de uma forma particular às tensões e conflitos originários do contato com a morte e seu estigma, construindo coletivamente defesas para mascará-los. Segundo Rasia (1996), essas defesas expressam a cultura organizacional que, para bem funcionar, precisa agir como se os indivíduos que atuam na organização hospitalar não fossem humanos. Portanto, certa distância é 
necessária, já que, se o intensivista se aproximar em demasia do enfermo, pode envolver-se com seu sofrimento, presença cotidiana no hospital. O comentário de um médico plantonista é ilustrativo: "Eu acho que hospital e sofrimento são coisas que correm juntas. É difícil dissociar e em terapia intensiva mais ainda".

A aproximação do profissional com o doente e seu sofrimento é percebida como uma ameaça à sua atuação técnica, como disse uma enfermeira referindo-se à possibilidade de 'envolvimento' com o paciente: "Quando eu vejo que a barreira está diminuindo, eu levanto ela de novo - eu fujo".

A identificação do profissional com a situação do doente ou do familiar pode levar à emergência de sentimentos e interferir em suas decisões e atitudes, o que pode ser exemplificado por um episódio ocorrido durante a pesquisa. Um médico 'recebia' o plantão de seu colega e, ao ouvir o relato do caso de um paciente de 11 anos, com o mesmo nome de seu filho, reagiu: "Deus me livre, que caso grave, e tem o mesmo nome do meu filho". Essa identificação influenciou claramente na decisão de alterar a medicação: "Diminui o Fentanil para 50 por horas, para o menino não chorar. Assim o pai não fica estressado, nem a gente, Deus me livre" (médico plantonista).

A sensibilização do profissional diante da situação dos pacientes geralmente não é bem vista pela equipe. $\mathrm{O}$ envolvimento é percebido como uma dissolução dos limites necessários à atitude profissional ideal. Nesse sentido, os mecanismos de gestão das emoções são cruciais para garantir a eficiência do trabalho. Nas ocasiões em que a barreira é rompida a equipe aponta, reclamando e acusando o colega, como disse um médico plantonista, em entrevista: "E todo mundo reclamava: o que é isso, você tá envolvido com um doente, você tá envolvido".

Apesar da vigilância e do controle exercidos pela equipe, em algumas ocasiões ocorrem envolvimentos, como disse uma enfermeira, em entrevista:

As minhas barreiras não foram suficientes e eu acabei levando o Carlos [nome fictício] pra minha casa. Aí eu chegava em casa e o meu marido perguntava: como é que foi o Carlos hoje? Eu trouxe a minha filha pra conhecer o Carlos. Sabe, Carlos, essa aqui é a minha filha. E lembro da cara dele direitinho, do sorriso que ele dava, um sorriso sem dente. Ele conheceu minha filha e eu conheci a esposa dele, as filhas, os filhos, os problemas, tudinho. Eu me envolvi de tal jeito. E ele ficou no CTI durante tanto tempo que ninguém agüentava mais o Carlos, ninguém queria prestar assistência ao Carlos. E me envolvi tanto com ele que, mesmo eu sendo enfermeira plantonista, eu ia prestar assistência direta a ele. 
A fala da enfermeira demonstra o deslocamento de sua função: usualmente uma enfermeira plantonista não presta assistência direta ao doente. Essa mudança de conduta causada pelo envolvimento é percebido pela equipe como um desvio do ideal, justificando assim o controle e a vigilância exercidos entre os profissionais.

O intensivista muitas vezes atua como se não fosse passível de adoecer ou morrer. Ao identificar-se com o doente, é forçado a lembrar-se de sua condição humana e finita, o que também ocorre quando algum membro da equipe adoece. Durante o período de observação, um auxiliar de enfermagem, muito querido por todos, foi internado na Unidade Coronariana. Ao retornar ao trabalho, todos comentavam, em tom de brincadeira, sua internação. $\mathrm{O}$ tom da conversa alterou-se quando ele iniciou seu relato:

Eu sempre achei que a pior coisa para um doente é tomar banho no leito. Não precisei passar por isso. Eu estava com uma fome danada, pedi um suco, e até essas quentinhas que eles dão para os doentes e que a gente torce o nariz eu comi tudo, com a maior satisfação. Arroz, feijão, legume, tudo estava ótimo. Sabe o quê... é diferente quando a gente fica do outro lado. Eu vi bem o que é ficar do outro lado. (auxiliar de enfermagem)

Essa fala apresenta a idéia da existência de dois territórios distintos, nitidamente separados por uma barreira. Entretanto, ao adoecer, penetrando no 'outro lado', o indivíduo não perde sua identidade profissional, como disse o mesmo auxiliar de enfermagem: "Sei que quase morri, depois que tudo passou me deu uma paúra. Mas, ao mesmo tempo eu estava cercado dos profissionais que conheço e confio. Eram meus colegas, tive o maior carinho e o maior apoio. Isso foi bom.

O temor da morte foi, de certo modo, minorado pelo conhecimento técnico e pela confiança na competência dos colegas. A partir de um contato tão íntimo com a morte em seu cotidiano, o profissional sabe que necessariamente se defrontará com a sua finitude. Com base nessa consciência, desenvolve também uma classificação sobre o morrer. Um médico plantonista, em entrevista, afirmou que "alguns pacientes morrem mal". Ao ser perguntado sobre o significado dessa frase, explicou:

Quando você tem uma disfunção de muitos sistemas, tem falências pulmonar, renal e cardíaca. Aí você tem uma alteração até do aspecto do corpo. Há uma quantidade de coisas ligadas ao corpo, fica realmente com um aspecto terrivel. É diferente de uma pessoa que morre agudamente de um enfarto, por exemplo. Eu acho que se eu tivesse de escolher, gostaria de morrer de enfarto. Um negócio rápido, uma arritmia. Não ficar aí no respirador, com os pulmões quase explodindo durante meses, semanas. É feio. 
Para uma enfermeira, "a morte digna é sem dor e sem consciência". Já para a psicóloga, "morrer bem é poder morrer em casa, com o apoio de sua família. Ter um pouco mais de dignidade, de qualidade de vida. Morrer mal é morrer dentro de um hospital".

Há um consenso nessas falas: o melhor, para o profissional, é morrer em sua própria casa, rapidamente, sem dor nem consciência. Em nossa sociedade, entretanto, é o que menos acontece, pois é no hospital que, de modo geral, se morre hoje em dia. A sociedade delegou aos hospitais e suas equipes de saúde os encargos da morte, à medida que foram sendo historicamente transformados e ocultados (Ariès, 1975). O profissional ocupa um lugar central nesse processo de rotinização e banalização da morte, mas, muitas vezes, se ressente desse posicionamento, sem possibilidades de alternativas. Contudo, é exatamente no enfrentamento da morte que o profissional demonstra a eficácia de seu saber e reafirma seu poder. Na última 'visita' que observei, ocorreu um episódio exemplar desse aspecto da prática médica. Discutia-se o caso de uma paciente de mais de oitenta anos, com morte cerebral comprovada. A médica plantonista orientava a equipe a não mais realizar manobras heróicas e questionou um colega residente:

Eu soube que, quando desci para resolver um assunto em outro setor do hospital, você não deixou que ela morresse. Por que você fez isso? A tendência, com a dosagem alterada, seria do eletrocardiograma ir retificando até chegar a uma linha reta, seria aos poucos. Eu não vejo sentido no que você fez.

Ao que o residente respondeu: "Chegou a dosagem do cálcio sangüíneo, estava baixo, e aí eu administrei cálcio e normalizou". A médica mais experiente perguntou: "Pra quê? Já sabemos que é questão de horas". A psicóloga perguntou então ao médico mais jovem: "O que você sentiu quando viu a dosagem baixa?" Ao que ele respondeu: "Eu não senti nada, fiz o que achei que deveria fazer. A dosagem estava alterada e eu a equilibrei. Eu sei que se a doente fizer uma parada, não vou tentar reanimá-la, mas equilibrar era tão fácil”.

O diálogo sintetiza uma das tensões presentes no CTI, onde não há espaço para debate sobre a ética de morrer com dignidade, mas sim para a valorização do saber e da técnica até no momento em que a morte é iminente e inevitável. A medicina, em nossa sociedade, com todo avanço tecnológico, chegou ao ponto de pretender - e às vezes conseguir - domesticar o fim da vida. 


\section{Notas}

1 Tradução de minha autoria. Marta Allué é antropóloga social, com mestrado em Antropologia da Medicina. Sofreu um acidente que causou queimaduras profundas em $80 \%$ de seu corpo, tendo sido interna em um CTI durante cinco meses. Sobreviveu, com seqüelas gravíssimas, e escreveu Perder la Piel, narrando sua vivência durante a internação e recuperação, quando já tinham se passado quatro anos após o acidente.

2 Parte-se do princípio que categorias culturalmente produzidas têm como referencial processos biológicos universais como, por exemplo, a idade, que não é um dado da natureza, mas uma construção social. Os períodos da vida - como processos biológicos - são elaborados culturalmente de formas distintas.

3 As denominações das diversas categorias são as utilizadas pela equipe intensivista, e as referentes aos eixos são de minha autoria.

4 A expressão 'escolha de Sofia' refere-se a um filme, no qual a personagem principal (Sofia), num campo de concentração, deveria escolher qual de seus dois filhos iria viver. Na situação observada, a escolha da médica mais experiente prevaleceu e o doente com Aids foi aceito no CTI.

5 A linguagem é jocosa, como em outras situações. Especialmente a partir da psicanálise, o humor é compreendido como revelador de verdades - às vezes difíceis - que só podem vir à tona por meio de chistes ou metáforas. E é também pela jocosidade que críticas se apresentam, como na fala de um médico, diante do exame de um doente: "são as mulambinas". Quando perguntado sobre o significado do termo, respondeu que são "as enzimas dos mulambos". 'Mulambo' é muito usado por profissionais da saúde, referindo-se a pacientes de nível socioeconômico baixo e em estado de extrema depauperação física. $\mathrm{O}$ termo pode ser compreendido não somente como uma crítica às condições de saúde do país, mas também pelas condições de trabalho do profissional da saúde. Sobre o tema, ver Petersen (1998) e Carrara (1998b).

6 As categorias referidas por Comelles, os que 'agüentam' e os que 'se deixam levar', são análogas ao 'responsivo' e 'morredor'. Segundo o autor, a noção de resistência do paciente é construída dia a dia. A resistência é associada à tarefa do intensivista, que lida com o corpo utilizando tecnologia de suporte vital e monitorização. Essa resistência, para Comelles, não é um fato biológico, vinculado ao corpo do doente, mas uma prática construída culturalmente por todos os envolvidos: equipe de saúde e paciente (Comelles, 1994).

7 Pode-se dizer, em concordância com Lívia Neves de Holanda Barbosa (1988), que o 'jeitinho' promove, dependendo de sua forma de utilização, homogeneizações positivas e negativas, sem nunca impor escolhas excludentes e definitivas. Tanto pode ser símbolo de uma desordem institucional como pode ser emblema de cordialidade e conciliação de interesses. DaMatta (1987 e 1990) considera que o dilema básico da sociedade brasileira seria a tensão entre os valores individualistas e hierárquicos. No primeiro pólo encontram-se os valores universalizantes e impessoais que 
buscam instaurar a igualdade: não há intermediação entre o indivíduo e a totalidade. Já a pessoa, personagem das sociedades tradicionais e hierárquicas, é o oposto do indivíduo. Seu contato com a totalidade é mediado por várias instâncias, como o clã, a linhagem e a família. A tensão entre os dois valores é expressa pelos intensivistas quando ocorre a internação de um paciente 'vip'. Por um lado, a equipe busca a cordialidade. Por outro, irrita-se com a intromissão em seu trabalho de instâncias hierarquicamente superiores.

8 O Conselho Federal de Medicina possui critérios de definição de morte cerebral elaborados por 12 cientistas, aprovados em 1997. De acordo com reportagem do Jornal do Brasil (23/02/99, $1^{\circ}$. Caderno) a classe médica considera que bastariam exames clínicos para a declaração de morte encefálica. Mesmo assim, os profissionais realizam exames complementares a fim de proteger os médicos de possíveis processos. Entretanto, alguns neurologistas questionam a fundamentação científica dos critérios de morte encefálica. O neurologista Cícero Galli Coimbra (Jornal do Brasil, 22/02/99, $1^{\circ}$. Caderno, p.5) afirmou que não há consenso a esse respeito, pois em vários países são utilizados tratamentos com excelente resposta, como a hipotermia, para pessoas declaradas mortas pelo conceito de morte encefálica. Segundo a reportagem, o especialista afirmou: "O conceito de que morte encefálica é morte não é mais verdadeiro. E em cima de uma mentira, montou-se toda uma infraestrutura de transplantes, inclusive com verbas públicas. O sistema de captação de órgãos, previsto na Lei de Transplantes, reservando leitos em UTIs, torna-se imoral por não esgotar todos os recursos terapêuticos, como a hipotermia, para salvar os pacientes antes de se transformarem em doadores". O debate segue em curso e os critérios oficiais ainda não foram alterados. 



\section{Conclusões}

Agora, neste momento de reflexão, é possível verificar que o estudo debruçou-se sobre as difíceis decisões em torno da vida e da morte. Portanto, o lugar ocupado pelo profissional de Centro de Terapia Intensiva é de extrema delicadeza. O ambiente do CTI é construído de modo a produzir uma reclusão, retirando de seus atores sociais a visibilidade do mundo. Trata-se de um lugar difícil e solitário, que isola quem está ali dentro - não se sabe se é dia ou noite, não se sabe se faz sol ou chove, não se sabe se está calor 'lá fora'. 'Lá fora' é uma expressão muito utilizada por quem está dentro do CTI: os profissionais não sabem se o doente será 'tão bem tratado lá fora'. Quem está 'ali dentro' não tem meios de controlar as condições do 'lá fora'; 'dentro' tudo é vigiado, regulado e dosado. Pode-se considerar o CTI uma "instituição total", nos termos de Goffman (1972: 13). Apesar de esse autor ter cunhado tal expressão com base na observação da vida dos internados em hospital psiquiátrico, a definição é adequada a esse setor do hospital: os indivíduos que ali estão - internados ou trabalhando nos plantões - são despidos de suas singularidades, estão submetidos a regras institucionais, compartilham uma situação de isolamento, separados do mundo exterior por determinado tempo.

A preservação da vida dos pacientes é tarefa essencial dos intensivistas, que, para tal, avaliam minuciosa e detalhadamente os 'parâmetros' das funções vitais dos doentes internados. A posição e a rotina de trabalho do profissional são liminares, como disse um médico: pode estar tudo tranqüilo, aparentemente 'sob controle', quando de repente algo acontece. O intensivista, então, deve agir de imediato para salvar uma vida. Logo, para afastar-se do setor, os colegas deverão ser avisados. A vida do profissional, quando 'dentro' do CTI, passa a se desenrolar em torno de inumeráveis detalhes, das prescrições, dos números e regulações. Quando 'dentro', fica-se totalmente imerso em outro mundo - o mundo do limiar entre a vida e a morte.

Pode-se afirmar, em concordância com Luiz Fernando Dias Duarte, que, "como todas as instituições públicas em nossa cultura, as que se ocupam da medicina e saúde sofrem os efeitos da 'racionalização' instrumental baseada na segmentação dos saberes e domínios de prática". Isso tem implicado 
a criação de serviços cada vez mais especializados, em que prevalece a atenção a dimensões isoladas dos 'doentes' ou das 'doenças'. Os CTIs parecem representar a forma mais aguda da tendência, no radical isolamento a que submetem seus usuários, em circunstâncias e condições freqüentemente vividas ou representadas como 'desumanas' ou 'despersonalizantes'. (Duarte, 2003: 177)

Outro aspecto de crucial importância diz respeito à tecnologia empregada na terapia intensiva. As máquinas utilizadas pela equipe, além de demarcar e controlar os 'parâmetros' de funcionamento dos órgãos dos pacientes ali internados, são importante referência para os profissionais de CTI. Pode-se afirmar que, em certo sentido, a tecnologia regula tanto a vida e a morte dos doentes como a própria vida dos profissionais em seu ambiente de trabalho. Desde o primeiro contato com a unidade, o visitante é recebido por um vídeo explicativo sobre as normas e regras do setor e sobre a aparelhagem. Assim, até o final da internação do paciente, a tecnologia e os diversos aparelhos ocupam um lugar central no CTI. Em algumas ocasiões o olhar inicial do visitante é dirigido às máquinas, atraído por seus 'bips' contínuos e ritmados e, só após algum tempo, se depara com os doentes a elas conectados.

A competência do intensivista vincula-se intimamente à tecnologia presente no CTI, de modo análogo à dependência dos diversos aparelhos, desenvolvida por alguns pacientes. Em seu aprendizado, o especialista do CTI imprime distintas densidades aos pólos da equação 'cuidado-competência', geralmente privilegiando a 'competência', constituída pela experiência no manejo da tecnologia. Algumas falas em entrevista são ilustrativas da idéia de que o intensivista 'cuida melhor dos doentes por contar com uma aparelhagem mais moderna e avançada'.

O isolamento do CTI, com seus aparelhos modernos e sofisticados, produz em outros setores do hospital a imagem de uma unidade 'fechada'. A tecnologia é requisito fundamental à assistência aos internados no CTI, doentes em iminente risco de vida, que os intensivistas julgam ter prioridade no acesso aos exames nos diversos laboratórios do hospital. Essa postura faz com que os intensivistas sejam criticados por seus pares por formarem uma 'elite' institucional, desfrutando de privilégios. Ao perceber essas críticas, o intensivista constrói um discurso reativo, produzindo tensão e conflitos na relação com os diversos setores do hospital. Ao mesmo tempo em que o profissional de CTI queixa-se da censura de seus pares dos outros serviços, ele os desqualifica, chegando a denominá-los de 'médicos leigos' ou, no extremo, de 'ignorantes'. Os 'de fora', segundo alguns intensivistas, 'não sabem muita coisa': principalmente não sabem utilizar a aparelhagem - 'e é facílimo'.

A Terapia Intensiva é considerada pelos próprios especialistas uma 'superespecialidade', ao englobar vários ramos da medicina. Um sistema hierarquizado 
de posições no campo das especialidades é construído, cabendo ao intensivista um lugar de poder privilegiado, no 'topo do hospital'. Sua competência apóia-se, em larga medida, em seus conhecimentos teóricos - produtores de um saber específico - e em sua capacitação no manejo da sofisticada aparelhagem.

A auto-imagem do intensivista é construída sobre ambigüidades e liminaridades: vida-morte, dentro-fora, podendo chegar até à razão-desrazão 'falta um parafusinho nos que escolhem o CTI', como dito por alguns profissionais. Há, pois, um ônus e uma glória no trabalho do intensivista. Ônus no desgaste - físico e emocional - da atividade intensa, e glória no heroísmo em salvar vidas. Um pólo não se apresenta sem seu oposto: sem o desgaste não há atividade heróica, e o heroísmo implica necessariamente um desgaste. O exercício profissional reitera a imagem dos componentes do setor como especiais, extraordinários e superiores. Uma imagem é então produzida: o intensivista como capaz de exercer domínio sobre a vida e a morte dos enfermos, mais propriamente com a capacidade de domesticar e regular a morte.

A questão, entretanto, não se resume à auto-imagem do intensivista. Ao longo do tempo, os médicos desenvolveram sua 'expertise' em numerosos domínios, relacionados diretamente ao valor dado ao corpo, tornando-se especialistas em decifrá-lo. A representação do profissional de CTI - tanto no meio profissional quanto mais amplamente - é construída sobre a imagem de salvador da saúde, da doença e da morte presentes em nossa sociedade ocidental. A medicina está profundamente enredada na imagem contemporânea do que se constitui como sofrimento e assume o lugar de esperança e libertação. Dizendo de outro modo, com o processo de medicalização da sociedade - produzido a partir de duas transformações históricas sociais, os cuidados prestados pelos religiosos passaram a ser exercidos pelos médicos, e o surgimento de uma nova organização e a 'disciplinarização' do espaço institucional (Foucault, 1979) - a esperança foi medicalizada. A salvação - ou uma parcela de sua representação - se encontra presente na eficácia técnica da medicina. Com as transformações históricas ocorridas no ocidente, a religião e seus representantes perderam seu espaço e importância no que concerne ao sofrimento, vida e morte.

Assim, o lugar ocupado pelo intensivista é de grande relevância e está inserido em uma equação bastante delicada. Por lidar justamente com estados no limiar da vida, seu saber, bem como o exercício prático referido a esse conhecimento, não podem e nunca poderão ser ordinários.

O intensivista ocupa um lugar privilegiado de poder na hierarquia da instituição. Sua posição pode caminhar de uma extrema potência - de domínio e 
domesticação da morte - até o limite da fragilidade humana. O paradoxo do exercício da prática intensivista se apresenta: ao trabalhar em última instância com a vida e a morte, o profissional entra em contato com um tênue equilíbrio. Ele pode salvar a vida de alguns, mas não de todos. Ao 'fracassar', confronta-se com a insuficiência de seus recursos.

Como o doente internado, o profissional vive em seu cotidiano uma guerra quase infinita. Entre suas armas, o especialista conta com o conhecimento e a perícia técnica que, entretanto, não são instrumentos suficientes para o desempenho de sua atividade prática. É necessário aliar certo tempo de experiência - o que conduz a um razoável equilíbrio na dupla dimensão constitutiva da prática médica. Para os profissionais aqui pesquisados, no atendimento ao doente, a habilidade técnica deve estar sempre acompanhada de um pólo humanitário, adquirido com o tempo de prática. Isto é, para que um profissional seja considerado experiente, deve atender aos doentes utilizando sua sensibilidade individual e singular, sensibilidade por ele recriada segundo um modelo hegemônico em seu meio profissional. Nesse processo de incorporação da própria vivência pragmática, a subjetividade do profissional entra em jogo. Os valores morais e culturais dos profissionais, relativos à raça, gênero, idade, preferências sexuais e hábitos dos enfermos, influenciam na própria concepção e prática do que vem a ser 'cuidado'. Tais aspectos não são, entretanto, objeto de transmissão pedagógica ao longo do curso de formação profissional, nem de avaliação ou questionamento nas diversas reuniões do setor.

A dupla dimensão estruturante - e inarredável - da medicina está presente em todo o trabalho desenvolvido pelos profissionais da unidade intensiva observada. O equilíbrio da delicada equação entre a competência e o cuidado (Good \& Good, 1993) ou, nos termos de Bonet (2004), o saber e o sentir - é objeto da assistência no CTI. Desde a seleção do doente a ser aceito nesse serviço uma série de variáveis entra em jogo: o estado físico do enfermo, suas possibilidades de benefício com a internação, sua idade, posição social, raça e gênero. Por vezes, para dois ou mais pedidos de outros setores do hospital, o intensivista deve selecionar apenas um paciente. Além dos dados ditos objetivos - os parâmetros das diversas funções vitais -, é possível que as representações sociais e culturais vigentes, em espectro mais amplo, influenciem decisivamente os profissionais nesse intrincado processo de tomada de decisão. Apesar de possuírem discernimento sobre o risco inerente à escolha - no dizer de um médico: "não se pode deixar de cuidar de uns porque pertencem a algum grupo específico, esse lugar não nos pertence" - inconscientemente os profissionais carreiam estigmas e valores correntes. A "escolha de Sofia" provoca ansiedade na equipe médica, 
aspecto que não é exclusivo dos intensivistas, mas compartilhado por grande parte dos profissionais da saúde que trabalham na assistência pública em saúde, em especial no atendimento em Prontos-Socorros (Deslandes, 2002).

No processo de escolha do paciente a usufruir uma vaga do CTI, a desqualificação social do idoso é exemplar. Ao expressar: "não traga mais vovôssauro, já chega de vovô aqui no CTI", o intensivista reforça uma representação social vigente. Desse modo, o profissional reitera valores e estigmas presentes em contexto social mais abrangente, incorporando-os em sua prática e assumindo o risco de privilegiar alguns - por considerá-los 'mais aptos' - em detrimento de outros. Em quem 'vale mais a pena investir' é uma das questões que se apresentam cotidianamente no exercício profissional de um CTI. Apesar de todas as referências a parâmetros 'objetivos' envolvidos no cuidar competente exercido pelo profissional, na tomada de decisões médicas se apresentam questões de grande complexidade.

Para Jane Seymour (2001), a escolha do paciente a ser admitido no CTI reflete tanto os padrões demográficos do hospital no qual esse serviço está inserido quanto da população em geral. Assim, uma crescente proporção dos pacientes internados em unidades intensivas tende a ser constituída por idosos, sofrendo processos de exacerbação de doenças crônicas. O intensivista tem consciência de que, por trás de todo o aparato tecnológico, há um conjunto de difíceis decisões éticas a serem processadas. Qualquer deslize, desatenção ou até mesmo erro de julgamento pode significar a perda de uma vida. Alguns médicos entrevistados abordaram de forma muito sincera os enganos de avaliação. Cabe ressaltar que o CTI observado está inserido em um hospital público universitário, espaço no qual as desigualdades e tensões sociais emergem de forma mais clara e evidente.

O 'sistema' de classificação dos pacientes utilizado pelos médicos obedece a uma estratégia de sobrevivência, seja para a preservação da cultura profissional na instituição, seja para a gestão das relações hierárquicas de poder. Talvez a 'rebeldia' e outros modos de comportamento dos doentes constituam estratégias de sobrevivência individual no hospital, permitindo reduzir os níveis de estranhamento, medo e ansiedade - ante uma instituição organizada com o objetivo de manutenção da vida física. O comportamento de não colaboração do enfermo pode ser compreendido como manifestação de estranheza diante dos procedimentos que seu corpo é alvo, conduzindo à perda de sua autonomia individual. Goffman (1972) e Strauss (1963), dentre outros autores, se dedicaram a investigar a instituição hospitalar, enfocando sobretudo a perda da autonomia dos doentes ali internados. A vida do hospital é regida por regras que devem ser aceitas pelo 
paciente. Na análise do material coletado para este estudo, abordou-se especialmente os processos interativos entre os diversos profissionais atores do CTI. Ao se tratar de internação em um CTI, as possibilidades de negociação tornam-se ainda mais reduzidas do que em qualquer outra unidade do hospital, seja pela minuciosa organização do setor, seja pela gravidade da enfermidade e pela restrita possibilidade de expressão verbal do doente.

A medicina contemporânea é centrada no combate à doença, categoria reificada, biologizada e assim tornada 'objetiva'. Entretanto, aquele que padece de um sofrimento é um indivíduo e, justamente por tal condição, é sujeito a uma variabilidade infinita de reações que podem escapar ao modelo descrito na literatura médica. Alguns requisitos são necessários ao profissional, no exercício do atendimento ao doente: conhecimentos teóricos e técnicos acumulados ao longo de certo tempo de experiência, além de uma distância do sofrimento vivido pelo enfermo. Precisamente pelo fato de o objeto de trabalho do profissional do CTI tratar-se de um ser humano, o especialista, para agir corretamente, necessita de certo distanciamento.

O afastamento não é exclusivo ao intensivista, faz parte de qualquer prática voltada ao cuidar competente. Assim como na observação etnográfica é necessário um movimento de aproximação e recuo, de identificação e estranhamento, o profissional de CTI, em seu cotidiano, não pode se posicionar completamente distante ou muito próximo ao enfermo e a seu destino. É um jogo de interações complexas, em que vários aspectos são relevantes. Por um lado, o médico não deve se 'aproximar' além de determinado limite, evitando o envolvimento com o sofrimento vivido pelo doente e seus familiares, para não comprometer um processo - 'ideal' - de tomada de decisões. Por outro lado, não deve também se 'afastar' em demasia do paciente, evitando o contato com a dor humana, correndo o risco de lidar com o enfermo apenas como objeto, perdendo a percepção de se tratar de uma pessoa com história e drama singulares.

Para realizar sua tarefa, o profissional constrói uma série de artifícios e formas de gestão dos sentimentos envolvidos. Por vezes resulta em certa distância dos dramas humanos inerentes à prática de qualquer agente de saúde. Não se trata de simplesmente condenar ou glorificar os diversos atores que atuam na cena do CTI, mas de apontar os riscos do distanciamento. O tempo é um dos aspectos a serem levados em conta na gestão das emoções. Para o intensivista, lidar com sentimentos - os seus, dos doentes ou familiares -, por vezes, é considerado 'perda de tempo'. Na equipe, essa tarefa é delegada à psicóloga, enquanto as outras categorias voltam-se para as funções dos órgãos, exames, medidas, 
procedimentos e terapêuticas. Como já descrito por diversos autores (Glaser \& Strauss, 1965; 1968; Herzlich, 1993a, dentre outros), essa forma de funcionamento não significa, no entanto, que os profissionais não se emocionem. Ao contrário, trata-se justamente da criação de diversos modos de administração de uma possível emergência de sentimentos, capaz de produzir transtornos ao funcionamento institucional. Como afirma Herzlich:
a 'cena' de um doente ou de um membro de sua família introduz o imprevisto e o incontrolável na rotina hospitalar. A angústia ou culpabilidade de um médico ou de uma enfermeira perturba sua capacidade de conduzir corretamente um conjun- to de tarefas já programadas. (Herzlich, 1993b: 10)

As principais formas de gestão das emoções utilizadas pela equipe são a fragmentação, a passagem para o sentimento oposto e o uso de medicamentos. A primeira se constata quando a equipe se refere ao paciente designando-o pelas partes de seu corpo, por seus parâmetros, órgãos e funções. Tal situação pode ser ilustrada pelo uso da expressão 'o eletroencefalograma está retificando', para significar o diagnóstico de morte cerebral. Cabe relembrar que, com os avanços tecnológicos produzidos pela ciência e aplicados à medicina na segunda metade do século XX, a morte deixou de ser um evento pontual. Foi transformada em um processo complexo e gradual, passível de decomposição analítica e de múltipla definição - morte cerebral, clínica e celular.

A passagem à emoção oposta é freqüente, em especial em reuniões de equipe, quando o desânimo ou o silêncio dominavam. O clima rapidamente se alterava, chegando à euforia, após uma piada ou um comentário qualquer. A ação por meio de medicamentos é uma outra forma de o profissional não entrar em contato com seu sentimento. As maneiras de gestão das emoções da equipe não são excludentes, podem somar-se e deslizar de uma para outra. A equipe, ao considerar como não conveniente à conduta dos familiares, lança mão de medicamentos tranqüilizantes, com o objetivo de afastar suas demandas e interferências. As preocupações dos parentes e amigos dos enfermos demandam do profissional um tempo e disponibilidade pessoal além dos limites considerados adequados pelo intensivista. A equação competência-cuidado se apresenta nos modos de gestão das emoções, com o profissional privilegiando a utilização eficiente de seu tempo.

O trabalho do profissional de CTI é desgastante - física e emocionalmente -, especialmente quando é preciso comunicar aos familiares que seu poder tem limites, que o objetivo almejado - a manutenção da vida - não foi atingido. Uma parcela do desgaste deve-se ao ônus, delegado socialmente ao médico, de cuidar dos doentes e dos que estão a morrer. Muitos dos profissionais entrevistados defendem a 
necessidade de um afastamento desse setor, após certo tempo de trabalho em CTI. Um fator adicional de desgaste é o número expressivo de mortes naquele local, freqüientemente referido na fala dos intensivistas entrevistados.

Pode-se dizer que, de certa forma, a morte vem sendo disciplinada ou mesmo abolida em nossa sociedade. Os rituais e o período de luto são cada vez mais rápidos e assépticos. Se a morte próxima é dissimulada, a dos anônimos, a dos 'outros' é exibida espetacularmente pela mídia, como um dos acessórios da vida diária. "Assim banalizada, a morte torna-se demasiado habitual para despertar emoções intensas" (Bauman, 1998: 199). Para Elias (1997, 1989), o ocultamento da morte integra o processo civilizador, iniciado no ocidente há mais de quinhentos anos. No século XX, a morte nos hospitais tornou-se fria e impessoal e, sobretudo, rigorosamente controlada pelo aparato médico.

Em uma sociedade que nega, oculta e 'rotiniza' a morte, valorizando a juventude, a saúde, a beleza e o desempenho do corpo jovem, receber o ônus social de cuidar dos doentes e moribundos é uma tarefa árdua, laboriosa e de extrema delicadeza. Cabe destacar o surgimento recente de uma proposta diferente em relação ao processo do morrer - os Cuidados Paliativos. No entanto, o tema escapa ao escopo deste livro.

O processo de tomada de decisões médicas relativas à vida e à morte dos pacientes de CTI revela-se de extrema complexidade. O intensivista, em posição liminar, deve decidir se retira ou não o soro, a medicação, a alimentação enteral, se reanima ou não determinado enfermo e com quais conseqüências. Em sua avaliação prática, entram em jogo representações sociais mais difundidas, muitas delas estigmatizantes e tensões peculiares e constitutivas da prática médica, presentes no eixo competência-cuidado. A equação é de difícil e intrincada resolução. Faz-se necessária ampla reflexão em domínios extensos - desde os terrenos das especialidades até aos não especialistas. Consegue-se hoje, por meio da tecnologia, postergar a morte, prorrogar a vida, mas questiona-se pouco sobre o custo de tal procedimento, tanto para o próprio doente e seus familiares, quanto para os profissionais. O indivíduo, como sujeito de sua vida e dos desígnios de sua morte, muitas vezes é silenciado, de modo análogo ao ocultamento dos sentimentos de seus próximos.

Nos últimos anos, termos foram criados para designar os diferentes tipos de morte: distanásia, para um processo do morrer lento, com excessiva invasão corporal e sofrimento; ortotanásia, para uma morte tranqüila, com um mínimo de sofrimento possível e eutanásia, referente à morte decidida por doente e médicos (Pessini, 2001). No entanto, os critérios de avaliação dessas modalidades de 
término da vida foram - e continuam sendo - exclusivos do aparato médico. Em outros termos, o ator social central, que categoriza, controla e administra o processo do morrer é o médico.

Atualmente há um fascínio diante dos avanços da ciência. Diariamente são publicados votos de louvor à ciência. A discussão centra-se nas técnicas de reprodução da vida, no seu prolongamento, no alargamento dos poderes da humanidade obtidos pelas pesquisas científicas. Para Bauman (1998), o acesso à vida mais longa já está tecnologicamente estratificado. A questão situa-se no centro de um debate ético. Muitas vezes o debate médico permanece restrito à discussão sobre a técnica da sobrevida, como em alguns exemplos citados, quando é discutido se as dosagens estão desequilibradas, se a morte é cardíaca, cerebral, ou se 'realmente' ocorreu o óbito.

Atingimos, hoje, um patamar de desenvolvimento tecnológico no qual é possível um certo domínio e regulação da morte - uma domesticação da morte. Cada vez mais capacitado a criar a vida, prolongá-la ou até interrompê-la, o médico encontra-se no centro de um debate bioético, uma vez que essas práticas dependem do seu saber, que está inserido em uma determinada estrutura de poder. O modelo de prática intervencionista é o dominante, reduzindo o doente à condição de instrumento de um saber como, por exemplo, na eutanásia e no suicídio assistido. Estes tornaram-se temas de amplo debate, abordando a autonomia do indivíduo e a abrangência social do poder médico diante de escolhas individuais. O suicídio assistido radicaliza o poder de decisão médica diante da morte e, indo além, transforma um acontecimento pessoal e íntimo em evento médico. Nos últimos anos tal debate vem sendo ampliado e divulgado pela mídia, em especial nos Estados Unidos. No entanto, no Brasil e, mais especificamente na assistência pública em saúde, há pouco espaço para interlocução entre equipe de saúde e pacientes.

A discussão ética no Brasil, entretanto, corre o risco de ficar restrita ao campo técnico da medicina. Cabe a proposta de ampliar o campo de debate incluindo uma parcela maior da sociedade, especialmente aqueles que não possuem voz: pacientes e seus familiares assistidos pelo sistema público de saúde. Inúmeras questões emergem com base nesse campo de investigação. Diante do fascínio pela tecnologia é possível uma ética de morrer com dignidade? De que forma? Como seria possível uma morte digna em um local no qual o funcionamento institucional, o controle das emoções e, sobretudo, os processos de objetificação e de fragmentação e da pessoa em órgãos e sistemas são preeminentes? Qual o lugar, papel e poder do médico? Serão as reflexões no 
interior do campo profissional suficientes? Em sua formação profissional, o médico recebe habilitação suficiente para lidar com tais dilemas éticos? A discussão deve prosseguir em âmbitos cada vez mais amplos, de modo algum permanecendo restrita ao terreno dos profissionais e especialistas da área da saúde. 


\section{Referências Bibliográficas}

ALLUÉ, M. Perder la Piel. Barcelona: Editorial Seix Barral, 1998.

ARIÈS, P. Essais sur L'histoire de La Mort en Occident, du Moyen Âge à Nos Jours. Paris: Éd. du Seuil, 1975.

ARIÈS, P. O Homem Diante da Morte. Rio de Janeiro: Francisco Alves Ed., 1981.

BARBOSA, L. N. de H. O jeitinho, ou a arte de ser mais igual que os outros. Ciência Hoje, 7 (42), 1988.

BAUMAN, Z. O Mal-Estar da Pós-Modernidade. Rio de Janeiro: Zahar, 1998.

BECKER, H. Boys in White. Chicago: University of Chicago Press, [1961] 1992.

BERK, J. L. \& SAMPLINER, J. E. Handbook of Critical Care. Boston: Little, Brown and Company, 1982.

BLANCHET, A. \& GOTMAN, A. L'enquête et ses méthodes: l'entretien. Paris: Éd. Nathan Université, 1992.

BONET, O. A. Saber e Sentir: uma etnografia da aprendizagem da Biomedicina. Rio de Janeiro: Ed. Fiocruz, 2004.

BOURDIEU, P. Esboço de uma teoria da prática. In: ORTIZ, R. (Org.) Pierre Bourdieu. São Paulo: Ática, 1994.

CANETTI, E. Vozes de Marrakech. Porto Alegre: L\&PM, 1987.

CARAPINHEIRO, G. Saberes e Poderes no Hospital: uma sociologia dos serviços hospitalares. Porto: Edições Afrontamento, 1998.

CARRARA, S. Crime e Loucura: o aparecimento do manicômio judiciário na passagem do século. Rio de Janeiro: Ed. Uerj/Ed.USP, 1998a.

CARRARA, S. Language, social context and 'etymological consciousness'. Cadernos de Saúde Pública, 14 (4), 1998b.

CIVETTA, J.; TAYLOR, R. \& KIRBY, R. Critical Care. Philadelphia: J.B. Lippincott Company, 1988.

COMELLES, J. M. La sacralización de la práctica hospitalaria. Del despliegue tecnológico a la institucionalización del milagro. In: BARONA, J. I. (Org.) Malaltia i Cultura. Tarragona: [s.n.], 1994. 
COSTA, J. F. História da Psiquiatria no Brasil. Rio de Janeiro: Ed. Documentário, 1976.

DA MATTA, R. O ofício de etnólogo, ou como ter 'anthropological blues'. In: NUNES, E. O. (Org.) A Aventura Sociológica. Rio de Janeiro: Zahar, 1978.

DA MATTA, R. A Casa \& a Rua: espaço, cidadania, mulher e morte no Brasil. Rio de Janeiro: Guanabara, 1987.

DA MATTA, R. Carnavais, Malandros e Heróis: para uma sociologia do dilema brasileiro. Rio de Janeiro: Guanabara, 1990.

DESLANDES, S. F. Frágeis Deuses: profissionais da emergência entre os danos da violência e a recriação da vida. Rio de Janeiro: Ed. Fiocruz, 2002.

DUARTE, L. F. D. Indivíduo e pessoa na experiência da saúde e da doença. Ciência e Saúde Coletiva, 8 (1): 173-183, 2003.

DUARTE, L. F. D. \& LEAL, O. F. (Orgs.). Doença, Sofrimento, Perturbação: perspectivas etnográficas. Rio de Janeiro: Ed. Fiocruz, 1998.

ELIAS, N. La Soledad de los Moribundos. México: Fondo de Cultura Económica, 1989.

ELIAS, N. O Processo Civilizador. Rio de Janeiro: Zahar, [1939] 1997.

FLECK, L. La Génesis y el Desarrollo de un Hecho Científico: introducción a la teoria del estilo de pensamiento y del colectivo de pensamiento. Madrid: Alianza Editorial, 1986.

FOUCAULT, M. Microfísica do Poder. Rio de Janeiro: Graal, 1979.

FOUCAULT, M. O Nascimento da Clínica. Rio de Janeiro: Forense Universitária, [1963] 1994.

FOUCAULT, M. História da Loucura na Idade Clássica. São Paulo: Perspectiva, [1961] 1995.

FREIDSON, E. The Hospital in Modern Society. London: Collier-Mac-Millan Limited, 1963.

FREIDSON, E. Profession of Medicine: a study of the sociology of applied knowledge. Chicago: University of Chicago Press, 1988.

GOFFMAN, E. Internados: ensayos sobre la situación social de los enfermos mentales. Buenos Aires: Amorrortu, [1961] 1972.

GLASER, B. \& STRAUSS, A. Awareness of Dying. Chicago: Aldine, 1965.

GLASER, B. \& STRAUSS, A. Time for Dying. Chicago: Aldine, 1968.

GOOD, B. J. Medicine, Rationality, and Experience: an anthropological perspective. New York: Cambridge University Press, 1997. 
GOOD, B. J. \& GOOD, M-J. D. V. Learning medicine. The construction of Medical Knowledge at Harvard Medical School. In: LINDEBAUM, S. \& COCH, M. (Eds.) Knowledge, Power and Practice: the anthropology of medicine and everyday life. California: Univ. of California Press, 1993.

HAMMERSLEY, M \& ATKINSON, P. Etnography: principles in practice. Londres e Nova York: Tavistock Publications, 1986.

HERZLICH, C. Médecine moderne et quête de sens: la maladie signifiant social. In: AUGÉ, M. \& HERZLICH, C. (Orgs.) Le Sens du Mal: anthropologie, histoire, sociologie de la maladie. Paris: Éd. des Archives Contemporaines, 1986.

HERZLICH, C. Os Encargos da Morte. Rio de Janeiro: Uerj/IMS, 1993.

KÜBLER-ROSS, E. On Death and Dying. New York: MacMillan Publishing Co., 1969.

MALINOWSKI, B. Objetivo, método e alcance desta pesquisa. In: ZALUAR, A. G. (Org.) Desvendando Máscaras Sociais. Rio de Janeiro: Francisco Alves Ed., 1980.

MENEZES, R. A. Difíceis Decisões: uma abordagem antropológica da prática médica em CTI, 2000. Dissertação de Mestrado, Rio de Janeiro: Instituto de Medicina Social/Universidade do Estado do Rio de Janeiro.

MENEZES, R. A. Etnografia do ensino médico em um CTI. Interface, 9: 117-132, 2001.

MENEZES, R. A. Em Busca da Boa Morte: antropologia dos cuidados paliativos. Rio de Janeiro: Ed. Fiocruz/Garamond, 2004.

MERTON, R. K.; READER, G. G. \& KENDALL, P. L. (Eds.) The Student-Physician: introductory studies in the sociology of medical education. Massachusetts: Harvard University Press, 1957.

PAIVA, M. R. Feliz Ano Velho. São Paulo: Brasiliense, 1983.

PESSINI, L. Distanásia: até quando prolongar a vida? São Paulo: Ed. do Centro Universitário São Camilo/Loyola, 2001.

PETERSEN, C. Medical slang in Rio de Janeiro, Brazil. Trambiclínicas, pilantrópicos e mulambulatórios. Cadernos de Saúde Pública, 14 (4): 671-682, 1998.

PINTO, P. G. H. da R. Saber Ver: recursos visuais e formação médica, 1997.

Dissertação de Mestrado, Rio de Janeiro: Instituto de Medicina Social/

Universidade Estadual do Rio de Janeiro.

PITTA, A. Hospital, Dor e Morte como Ofício. São Paulo: Hucitec, 1991.

RASIA, J. M. Hospital: socialidade e sofrimento. Tese para o concurso de Professor Titular de Sociologia das Organizações, Departamento de Ciências Sociais. Curitiba: Universidade Federal do Paraná, 1996.

REGO, S. O processo de socialização profissional na medicina. In: MACHADO, M. (Org.) Profissões de Saúde: uma abordagem sociológica. Rio de Janeiro: Ed. Fiocruz, 1995. 
SEYMOUR, J. E. Critical moments: death and dying in Intensive Care. Buckingham: Open University Press, 2001.

SIMÃO, A. T. Terapia Intensiva. Rio de Janeiro: Atheneu, 1976.

STRAUSS, A. The hospital and its negotiated order. In: FREIDSON, E. (Ed.) The Hospital in Modern Society. London: Collier-MacMillan Limited, 1963.

STRAUSS, A. La Trame de la Négociation. Paris: Éd. L'Harmattan, 1992.

SUDNOW, D. Passing On: the social organization of dying. New Jersey: PrenticeHall, 1967.

VELHO, G. Observando o familiar. In: NUNES, E. (Org.) A Aventura Sociológica. Rio de Janeiro: Zahar, 1981. 


\section{Glossário}

AE: aluno excepcional, deficiente mental.

ALBUMINA: proteína utilizada para avaliação do estado de nutrição do paciente.

ACIDOSE: alteração do pH do sangue, que pode ser causada por diversas alterações metabólicas ou respiratórias.

ACINECTOBACTER: um tipo de bactéria.

ALIMENTAÇÃO ENTERAL: alimentação através de sonda que libera o alimento diretamente no intestino.

AMBU: aparelho para ventilação manual.

ANALGESIA: ação contra a dor.

ATELECTASIA: colapso de uma porção de um pulmão.

BRADICARDIA: lentificação dos batimentos cardíacos.

BRONCOESPASMO: contração dos brônquios.

BRONCOSCOPIA: exame para visualização direta da traquéia e dos brônquios.

CINTIGRAFIA PULMONAR: exame realizado com rádio-isótopos para avaliar a ventilação dos pulmões.

CINTIGRAFIA PULMONAR DE PERFUSÃO: exame realizado com rádio-isótopos para avaliar a perfusão, isto é, a passagem de sangue através dos tecidos dos pulmões.

COR PULMONALE: comprometimento cardíaco em decorrência de patologia pulmonar.

DESMAME: processo gradual de retirada de ventilação artificial.

DIÁLISE: processo de filtração do sangue.

DIAZEPAN: medicação ansiolítica, popularmente conhecida como Valium ou Dienpax.

DIETA HIPERLIPÍDICA: alimentação rica em gorduras

DISSECÇÃO VENOSA: pequena cirurgia realizada com o intuito de introdução de um cateter em veia profunda.

DM: diabetes mellitus.

DPOC: doença pulmonar obstrutiva crônica.

ECOCARDIOGRAMA: ultra-som do coração, que avalia anatomia e função desse órgão.

EDA: endoscopia digestiva alta. 
EDEMACIADO: inchado.

EMBOLIZANDO: formando êmbolos, ou seja, coágulo sangüíneo que se desprende e migra para pontos distantes da circulação, por exemplo, cérebro, pulmão, rins etc.

ENDOSCOPIA: exame para visualização direta da porção alta do aparelho digestivo.

ENTUBAÇÃO: colocação de tubo na traquéia, para respiração assistida.

FENTANIL: medicação anestésica.

GASOMETRIA: exame que avalia o pH e a pressão parcial do oxigênio e gás carbônico no sangue.

GASTRO: gastroenterologista, médico especializado em doenças do aparelho digestivo.

HALDOL: nome comercial do Haloperidol, medicação psiquiátrica com ação antipsicótica.

HAS: hipertensão arterial sistêmica.

HD: hemodiálise, sinônimo de diálise, processo de filtração do sangue.

HEPARINA: substância anticoagulante.

HIPERTENSO: doente com pressão arterial elevada.

IAM: infarto agudo do miocárdio.

ISQUEMIADE PAREDEANTERO-SEPTAL: diminuição da irrigação sangüínea na parede anterior do coração

KLEBSIELLA: um tipo de bactéria.

LASIX: nome comercial da furosemida, que é uma substância diurética

LEXOTAN: nome comercial do Bromazepan, substância com ação ansiolítica, que atua contra a ansiedade.

LÚPUS: lúpus eritematoso sistêmico, um tipo de doença auto-imune.

MEROPENEM: um tipo de antibiótico.

NEFROLOGIA: especialidade referente aos rins.

NEGATOSCÓPIO: aparelho para visualização de exames radiográficos (raios X).

PNEUMO: pneumologista, médico especializado em doenças do aparelho respiratório.

PNEUMONIA COMUNITÁRIA: pneumonia adquirida fora do ambiente hospitalar, no ambiente onde a pessoa vive.

PROCEDIMENTO: termo amplamente utilizado por equipes de saúde. Refere-se à retirada de sangue ou outras condutas, como punção arterial, dissecção de veia profunda, entubação e colocação de prótese respiratória.

PRÓTESE RESPIRATÓRIA: ventilação através de respirador artificial.

PUNÇÃO: aspiração de líquido do interior do organismo, por exemplo, sangue, pus etc.

SEDAÇÃO: uso de substâncias com o intuito de acalmar o paciente, muitas vezes causando sonolência. 
STAFILO: abreviatura de Staphylococcus, um tipo de bactéria.

TAP: tempo e atividade de protrombina, exame utilizado para o controle de ação da medicação anticoagulante.

TAQUIPNÉIA: respiração acelerada.

TC: tomografia computadorizada.

TRIDIL: nome comercial da nitroglicerina venosa, substância de ação vasodilatadora coronariana.

ÚLCERA DE PRESSÃO: escara, ferida provocada em geral pelo paciente permanecer por longo tempo deitado ou na mesma posição.

VANCO: vancomicina, um tipo de antibiótico.

VENTILAÇÃO MANUAL: ventilação pulmonar realizada através de aparelhos manuais, como, por exemplo, o ambu.

VENTILAÇÃO MECÂNICA: ventilação pulmonar realizada através de respiradores artificiais automáticos.

VITAMINA K: um tipo de vitamina, com ação coagulante. 
Formato: $21 \times 28 \mathrm{~cm}$

Tipologia: BauerBodni BT

Times New Roman

Papel: Print Max 90g $/ \mathrm{m}^{2}$ (miolo)

Cartão Supremo $250 \mathrm{~g} / \mathrm{m}^{2}$ (capa)

Fotolitos: Engenho \& Arte Gráfica Ltda. (capa e miolo)

Reimpressão e acabamento: Imprinta Express Grafica e Editora Ltda.

Rio de Janeiro, outubro de 2006.

Não encontrando nossos títulos em livrarias, contactar a EDITORA FIOCRUZ:

Av. Brasil, 4036 - 1ㅇ andar - sala 112 - Manguinhos

21040-361 - Rio de Janeiro - RJ

Tel.: (21) 3882-9039 e 3882-9041

Telefax: (21) 3882-9007

http://www.fiocruz.br/editora

e-mail: editora@fiocruz.br 